\title{
Nederlandse notenteelt
}

Kennis en innovatie ten behoeve van de ontwikkeling van notenteelt in Nederland

Auteurs | Henk van Reuler, Maureen Schoutsen, Fogelina Cuperus, Marianne Groot, Joran Keur, Marc Ravesloot \& Huub Schepers

\section{WAEENINGEN}

UNIVERSITY \& RESEARCH 


\section{Nederlandse notenteelt}

Kennis en innovatie ten behoeve van de ontwikkeling van notenteelt in Nederland

Henk van Reuler ${ }^{1}$, Maureen Schoutsen ${ }^{1}$, Fogelina Cuperus1, Marianne Groot' ${ }^{1}$, Joran Keur ${ }^{2}$, Marc Ravesloot ${ }^{1}$ en Huub Schepers

${ }^{1}$ Wageningen University \& Research Open Teelten

${ }^{2}$ Student Universiteit Utrecht

Dit onderzoek is in opdracht van het ministerie van Landbouw, Natuur en Voedselkwaliteit uitgevoerd door de Stichting Wageningen Research (WR), business unit Open Teelten, in het kader van beleidsondersteunend onderzoek "Mest, Milieu en Klimaat".

WR is een onderdeel van Wageningen University \& Research, samenwerkingsverband tussen Wageningen University en de Stichting Wageningen Research.

Wageningen, juli 2020

Rapport WPR-843 
Reuler, H. van, Schoutsen, M., Cuperus, F., Groot, M., Keur. J., Ravesloot, M., Schepers, H., 2020. Nederlandse Notenteelt; Kennis en innovatie ten behoeve van de ontwikkeling van notenteelt in Nederland. Wageningen Research, Rapport WPR-843.

Dit rapport is gratis te downloaden op https://doi.org/10.18174/525171

Trefwoorden: walnoten, hazelnoten, nieuwe rassen, teeltsystemen, koolstofopslag in gewas en bodem, referentiepercelen, economie, saldoberekening, notenketen, afzet

(C) 2020 Wageningen, Stichting Wageningen Research, Wageningen Plant Research, Business unit Open teelten, Postbus 200, 6670 AE Zetten; T 0488 473702; www.wur.nl/plant-research

KvK: 09098104 te Arnhem

VAT NL no. 8113.83.696.B07

Stichting Wageningen Research. Alle rechten voorbehouden. Niets uit deze uitgave mag worden verveelvoudigd, opgeslagen in een geautomatiseerd gegevensbestand, of openbaar gemaakt, in enige vorm of op enige wijze, hetzij elektronisch, mechanisch, door fotokopieën, opnamen of enige andere manier zonder voorafgaande schriftelijke toestemming van Stichting Wageningen Research.

Stichting Wageningen Research is niet aansprakelijk voor eventuele schadelijke gevolgen die kunnen ontstaan bij gebruik van gegevens uit deze uitgave.

Rapport WPR-843 


\section{Inhoud}

$\begin{array}{ll}\text { Samenvatting } & 7\end{array}$

1

Inleiding en leeswijzer $\quad 9$

$\begin{array}{lll}1.1 & \text { Inleiding } & 9\end{array}$

$\begin{array}{llr}1.2 & \text { Leeswijzer } & 10\end{array}$

$\begin{array}{ll}\text { Cultuur en Gebruikswaarde Onderzoek } & 11\end{array}$

2.1 Inleiding 11

2.2 Doel 11

2.3 Bescherming genetisch materiaal en raszuiverheid $\quad 12$

2.4 Internationale inbedding en internationaal netwerk $\quad 12$

3.1 Inleiding $\quad 13$

3.2 Aanpak 13

3.3 Resultaten walnootrassen 13

3.4 Nieuwe onderstammen voor Juglans regia 13

3.5 Fenologie 14

3.6 Voor- en nadelen in vitro ten opzichte traditionele vermeerderingsmethoden 15

3.7 Aanknopingspunten voor intensivering van de productie 15

3.8 Laterale dracht en dwerggroei 16

3.9 Suggesties voor een eerste aanplant met relatief recent ontwikkelde rassen 16

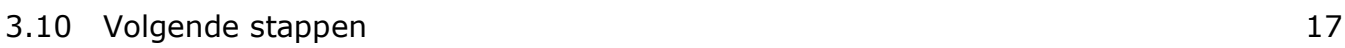

$\begin{array}{llr}4 & \text { Teeltsystemen } & 19\end{array}$

$\begin{array}{lll}4.1 & \text { Inleiding teeltsystemen } & 19\end{array}$

$\begin{array}{lll}4.2 & \text { Hazelnoot } & 19\end{array}$

$\begin{array}{lll}4.3 \text { Walnoot } & 21\end{array}$

$5 \quad$ Koolstofopslag $\quad 23$

$5.1 \quad$ Theoretisch kader en literatuurstudie koolstofopslag potentieel 23

5.2 Koolstofopslag in bovengrondse en ondergrondse biomassa $\quad 24$

5.2.1 Koolstofopslag en verschillende bepalingen gebruikt voor walnotenbomen 24

5.2.2 Bepalingen van koolstofopslag in hazelnotenteelt 26

5.3 Opslag in bodemorganisch koolstof (SOC) 28

5.3.1 Koolstofopslag in bodem onder walnotenbomen 28

5.4 Modellering van koolstofopslag in boven- en ondergrondse biomassa en bodem 29

$\begin{array}{ll}5.4 .1 \text { CO2Fix } & 30\end{array}$

$\begin{array}{ll}5.4 .2 \text { Yield-SAFE } & 30\end{array}$

6.1 Onderzoeksopzet 33

6.2 Omschrijving bedrijfssystemen notentelers 33

6.2.1 Walnotengaard bij Luttelgeest $\quad 33$

6.2.2 Walnotengaard in Herveld 33

6.2.3 Hazelnotengaard in Breedenbroek $\quad 34$

6.2.4 Hazelnotengaard in Lelystad $\quad 34$ 
6.3 Bodembemonstering voor organische koolstofmetingen en bepaling van de dichtheid

6.3.1 Grondbemonstering Breedenbroek, Lelystad en Herveld 36

6.3.2 Bodembemonstering Luttelgeest $\quad 37$

6.3.3 Verwerking van bodemmonsters door Eurofins $\quad 37$

6.3.4 Meting volumieke massa $\quad 37$

6.4 Berekening bodemorganisch koolstof per hectare $\quad 37$

6.5 Hoogte van bomen en diameter op borsthoogte (DBH) 37

6.5.1 Schatting biomassa in walnotengaarden 38

6.5.2 Schatting biomassa in de hazelnotengaarden 38

$\begin{array}{lll}6.6 & \text { Resultaten } & 38\end{array}$

6.6.1 Koolstofopslag in boven- en ondergrondse biomassa van de notenbomen 38

$\begin{array}{lll}6.7 & \text { Discussie } & 39\end{array}$

6.7.1 Koolstofopslag in boven- en ondergrondse biomassa 39

6.7.2 Koolstofopslag in bodem $\quad 40$

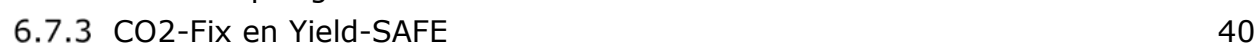

6.8 Aanvullende opmerkingen 41

6.9 Conclusie en aanbevelingen $\quad 41$

$\begin{array}{lll}7.1 & \text { Inleiding } & 43\end{array}$

$\begin{array}{lll}7.2 & \text { Gebruikte economische begrippen } & 43\end{array}$

$\begin{array}{lll}7.3 & \text { Walnoot } & 43\end{array}$

$\begin{array}{lll}\text { 7.3.1 Inleiding } & 43\end{array}$

$\begin{array}{lll}7.3 .2 \text { Prijs } & 44\end{array}$

$\begin{array}{ll}\text { 7.3.3 Productie } & 44\end{array}$

$\begin{array}{ll}\text { 7.3.4 Gewichtsverlies } & 45\end{array}$

$\begin{array}{ll}7.3 .5 \text { Arbeid } & 45\end{array}$

$\begin{array}{ll}\text { 7.3.6 'Worse case' } & 45\end{array}$

7.3.7 Scenario: Gras als ondergewas $\quad 45$

$\begin{array}{lll}7.4 & \text { Hazelnoot } & 46\end{array}$

$\begin{array}{ll}7.4 .1 & \text { Inleiding }\end{array}$

$\begin{array}{ll}7.4 .2 \text { Prijs } & 46\end{array}$

$\begin{array}{ll}7.4 .3 \text { Productie } & 47\end{array}$

$\begin{array}{ll}7.4 .4 \text { Arbeidskosten } & 47\end{array}$

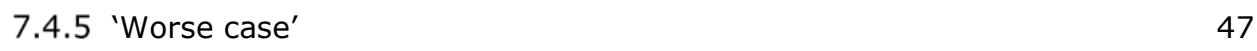

$\begin{array}{ll}7.4 .6 \text { Discussie } & 47\end{array}$

$\begin{array}{lll}7.5 & \text { Algemene conclusie } & 48\end{array}$

$8 \quad$ Communicatie en samenwerking in de notenketen $\quad 49$

$\begin{array}{lll}8.1 & \text { Inleiding } & 49\end{array}$

$\begin{array}{lll}8.2 & \text { Communicatie en netwerkvorming } & 49\end{array}$

8.2.1 Kennisoverdracht en netwerkvorming op de Nederlandse Notendag 49

8.2.2 Spelers in de notenketen en huidige afzetkanalen $\quad 50$

8.2.3 Opschaling Nederlandse notenteelt en marktkansen 50

$\begin{array}{lll}8.3 \text { Discussie } & 51\end{array}$

8.3.1 Aanbevelingen $\quad 52$

9 Slotopmerkingen $\quad 55$

$\begin{array}{ll}\text { Referenties } & 56\end{array}$

Bijlage 1 Lijst aangeboden walnootrassen in Nederland (niet uitputtend) 64

Bijlage 2 Rassenlijst Walnoot (vanaf 1990, bijgewerkt december 2018) 69

Bijlage 3 Suggesties voor eerste aanplant onafhankelijke toetsing $\quad 74$

Bijlage 4 Hazelnoot systeemgegevens $\quad 75$ 
$\begin{array}{lll}\text { Bijlage } 6 & \text { Resultaten bodemanalyses referentiepercelen } & 80\end{array}$

$\begin{array}{lll}\text { Bijlage } 7 & \text { Saldoberekening walnoot } & 82\end{array}$

$\begin{array}{lll}\text { Bijlage } 8 & \text { Saldoberekening hazelnoot } & 83\end{array}$

Bijlage 9 Programma Nederlandse Noten-dag (Zoelen, 10 november, 2018) 84

Bijlage 10 Presentatie op de Eerste Nederlandse Notendag(Zoelen, 10 $\begin{array}{ll}\text { november, 2018) } & 85\end{array}$

Bijlage 11 Infosheet project Nederlandse Notenteelt (december, 2018) 91 



\section{Samenvatting}

De Nederlandse landbouw heeft als doelstelling de emissie van broeikasgassen in 2030 met $49 \%$ te hebben verminderd. Welke rol kunnen 'nieuwe' gewassen hierbij spelen? In dit rapport wordt de potentiele bijdrage van noten (hazelnoot en walnoot) beschreven. Het onderzoek naar walnoten en hazelnoten heeft na 1990 in Nederland vrijwel stil gelegen. In het buitenland zijn verschillende nieuwe onderstammen en nieuwe rassen ontwikkeld die mogelijk geschikt zijn voor teelt onder Nederlandse omstandigheden. Indien geschikt kunnen hierdoor mogelijkheden ontstaan de teelt te intensiveren. Hiervoor is het nodig dat Cultuur en Gebruikswaarde Onderzoek (CGO) wordt gestart om de geschiktheid van nieuwe rassen en onderstammen te testen. Het is aan te bevelen noten op te nemen in het lopende CGO van appel en peer.

Op dit moment bedraagt het areaal hazelnoten en walnoten minder dan 100 ha. Door de geringe omvang is er weinig informatie beschikbaar over de optimale teelt omstandigheden. In verschillende landen is er onderzoek uitgevoerd naar het relatie tussen plantdichtheid, boomvorm en opbrengst. Plantdichtheden zijn afhankelijk van de groeiomstandigheden, beschikbare cultivars, beschikbare machines en voorkeur van de teler. Soms wordt geplant in hoge dichtheid en tijdens de groei wordt er gedund tot de uiteindelijke gewenste dichtheid.

De notenteelt kan door koolstofvervanging, vermindering van broeikasgas uitstoot en koolstofopslag een bijdrage leveren aan de klimaatmitigatie. In deze studie is vooral gekeken naar zowel de koolstofopslag in boven- en ondergrondse biomassa als in de bodemorganische stof. Er zijn geen Nederlandse studies beschikbaar naar de accumulatie van koolstof in de tijd van notenbomen. In de beschikbare buitenlandse literatuur zijn vooral studies beschreven naar de rol van walnoten bij deze koolstofopslag. Voor simulatietoepassingen worden twee bestaande modellen voor modellering van koolstofopslag in houtachtige gewassen beschreven: CO2Fix en Yield-SAFE. Om de potentiele bijdrage van de notenteelt aan de klimaatmitigatie onder Nederlandse omstandigheden te onderzoeken is het nodig om de gewasontwikkeling op een aantal representatieve percelen gedurende een meerjarige periode te volgen. Hiervoor zijn een aantal referentiepercelen geselecteerd en gekarakteriseerd: twee walnotenpercelen en twee hazelnoten pecelen. De geschiedenis van deze boomgaarden is beschreven, evenals de (methode voor) monstername. Hiermee is de uitgangssituatie vastgelegd van een mogelijk meerjarig monitoringsproject.

Ondernemers willen voordat ze overgaan tot de aanplant van noten graag inzicht hebben in de verwachte financiële opbrengsten. Na een toelichting op een aantal gebruikte economische begrippen zijn op basis van de beschikbare gegevens een aantal scenarioberekeningen uitgevoerd. Voor walnoten is er ook een scenario doorgerekend waarbij in de beginjaren van de aanplant gras als tussengewas wordt geteeld. Alle uitgevoerde berekeningen zijn saldoberekeningen omdat door gebrek aan informatie geen betrouwbare kostprijsberekeningen kunnen worden uitgevoerd.

De recent opgericht Nederlandse Notenvereniging speelt een belangrijke rol in de uitwisseling van kennis en ervaring tussen stakeholders in de notenketen. Het gaat hierbij om onderwerpen zoals rassenkeuze maar ook verwerking en huisverkoop. De tussenresultaten uit deze studie zijn dan ook op verschillende door de Notenvereniging georganiseerde bijeenkomsten gepresenteerd. Met betrekking tot de afzet van Nederlandse noten is kwaliteitsborging een belangrijk aandachtspunt. Voor optimale productverwaarding en afzetvergroting zullen (meer) marktpartijen moeten aanhaken. Ook is consumentenonderzoek aan te bevelen om te onderzoeken of consumenten een meerprijs willen betalen voor regionaal geproduceerde noten(producten) die op een bepaalde manier zijn geproduceerd (onder voorwaarden van bijvoorbeeld een Fair Trade keurmerk) en met een bepaald doel (bijvoorbeeld verhoging van de landschappelijke waarde). 


\section{Inleiding en leeswijzer}

\subsection{Inleiding}

De Nederlandse landbouwsector staat voor een meervoudige opgave. De nationale en internationale zorgen over de teruggang van biodiversiteit, de verwachte dalende trend in gebruik, mogelijkheden en acceptatie van gewasbeschermingsmiddelen, effecten van klimaatverandering en bedreigingen van de bodemkwaliteit vormen een andere context en verschuivende randvoorwaardes voor ontwerp en management van bestaande plantaardige productiesystemen. Binnen deze veranderende context zorgen marktontwikkelingen, (meer) aandacht voor gezond voedsel en de herkomst van dit voedsel voor nieuwe kansen en introductie van nieuwe gewassen, waaronder noten.

Notenteelt in Nederland biedt mogelijk antwoorden op de bovengenoemde uitdagingen. In deze studie hebben we ons beperkt tot de teelt van hazelnoten en walnoten.

Zo hebben de landbouw en landgebruik als doelstelling de emissie van broeikasgassen in 2030 met $49 \%$ te hebben verminderd. De vastlegging van $\mathrm{CO}_{2}$ in bodems en (houtige) vegetatie speelt een belangrijke rol om deze doelstelling te realiseren. Daarnaast leveren houtige gewassen een bijdrage aan de biodiversiteit en kwaliteit van het landschap. Het Voedingscentrum heeft in 2016 noten, 'een handje noten per dag', aan de schijf van vijf toegevoegd. Noten kunnen ook een rol spelen in de eiwittransitie als bron van eiwit en gezonde vetten.

Dit samen maakt dat de notenteelt belangrijke agro-ecosysteemdiensten levert. Ook zijn noten robuuste gewassen welke geteeld kunnen worden met geen tot beperkt gebruik van meststoffen en gewasbeschermingsmiddelen.

Op dit moment bedraagt het areaal noten (wal- en hazelnoten) in Nederland minder dan 100 hectare. Recent is de interesse in de notenteelt toegenomen. De toenemende vraag naar (lokaal en duurzaam geproduceerde) noten én de zoektocht en interesse in duurzame plantaardige productiesystemen (natuur inclusief, klimaatneutraal, verbetering bodemkwaliteit, agroforestry, voedselbossen etc.) die voldoen aan een breed scala aan agro-ecosysteemdiensten, wordt gehoord in de sector. Deze toegenomen belangstelling voor de notenteelt bij ondernemers heeft er toe geleid dat in juli 2017 de Nederlandse Notenvereniging is opgericht. Het doel van de vereniging is: 'De teelt van noten (walnoten, hazelnoten en andere noten) in ons land te stimuleren. De Vereniging behartigt de belangen van de leden op het gebied van teelt, bewaring, afzet en verwerking van noten.' Bij de uitvoering van deze studie is regelmatig contact geweest met de notenvereniging.

Dit onderzoeksproject is uitgevoerd in het kader van de Klimaatenvelop 2018 en is gefinancierd door het ministerie van Landbouw, Natuur en Voedselkwaliteit. Het onderzoek is grotendeels uitgevoerd in 2018.

De projectdoelstellingen waren:

- Het inventariseren en bundelen van kennis en ervaring met huidige notenteelt;

- Het uitvoeren van een verkenning van voor Nederland geschikte cultivars en onderstammen op basis van literatuurgegevens en praktijkervaringen;

- Het selecteren van geschikte proefpercelen ten behoeve van metingen en monitoring op gebied van agro-ecosysteemdiensten, evenals het uitvoeren van zgn. nulmetingen (op het gebied van koolstofopslag) op deze percelen;

- Het uitvoeren van een verkenning van de economische rentabiliteit van notenteelt;

- $\quad$ Een verkenning naar de communicatie en samenwerking in de notenketen.

De diverse deelonderzoeken zijn uitgevoerd door verschillende onderzoekers van Wageningen University \& Research, Open Teelten. Het deelonderzoek Koolstofopslag en Referentie percelen is onderdeel van een studentenonderzoek. 


\subsection{Leeswijzer}

Hoofdstuk 2 en 3 zijn met elkaar samenhangende hoofdstukken, waarbij in Hoofdstuk 2 wordt ingegaan op het hoe en waarom van Cultuur en Gebruikswaarde onderzoek (onderzoek naar nieuwe rassen) en in Hoofdstuk 3 (Literatuur quick scan walnoot Juglans regia ) kort wordt beschreven wat de meest veelbelovende ontwikkelingen van de walnotenteelt zijn waarover sinds 1990 in de wetenschappelijke literatuur is gerapporteerd. De laatste paragraaf van Hoofdstuk 3 (§ 3.12 ) geeft de aanbevelingen voor vervolg rassenonderzoek van walnoten. Hoofdstuk 4 gaat in op de teeltsystemen van wal- en hazelnoot; wat is er bekend op gebied van optimale teelt omstandigheden en plantdichtheden? Hoofdstuk 5 en 6 zijn ook weer met elkaar samenhangende hoofdstukken, waarbij Hoofdstuk 5 in gaat op het theoretisch kader van koolstofopslag en weergeeft wat er in de literatuur bekend is over het potentieel van de notenteelt voor koolstofopslag. Ook worden twee verschillende modellen beschreven. Hoofdstuk 6 geeft een kwantitatieve evaluatie van de effecten van notengaarden op de levering van de agro-ecosysteemdienst koolstofopslag in vergelijking met eenjarige teeltsystemen. Tevens worden een viertal referentie percelen beschreven die mogelijk in een meerjarig vervolgproject gemonitord kunnen worden.

Hoofdstuk 7 gaat over de economie van notenteelt en geeft saldoberekeningen voor hazelnoot en walnoot weer. Hoofdstuk 8 (Communicatie en samenwerking in de notenketen) gaat in op de activiteiten die in het kader van de communicatie door het onderzoeksteam van onderhavige Nederlandse notenteelt-studie zijn ondernomen, bediscussieert de notenketen en markt en doet aanbevelingen voor verdere verkenningen rondom het thema markt. Het rapport wordt afgesloten met een aantal slotopmerkingen in Hoofdstuk 9. 


\section{Cultuur en Gebruikswaarde Onderzoek}

\subsection{Inleiding}

Bij de ontwikkeling van een nieuw fruit- of notenras kunnen twee verschillende fasen worden onderscheiden, het veredelen en het Cultuur- en Gebruikswaarde Onderzoek (CGO).

Het kruisen of veredelen wordt gedaan door gespecialiseerde bedrijven, onderzoeksinstituten, boomkwekers of particulieren. Sommige bedrijven zijn privaat gefinancierd en andere worden (deels) door de overheid gefinancierd. Veelbelovende nieuwe rassen worden daarna in z.g. Cultuur- en Gebruikswaarde Onderzoek (CGO) verder onderzocht. In dit hoofdstuk worden het veredelingsproces en CGO beschreven voor appel. Hazelnoten en walnoten kunnen in dit onderzoek worden opgenomen.

Wageningen Universiteit \& Research (WUR) had zelf tot voor kort een appel veredelingsprogramma. Ieder jaar werden nieuwe kruisingen gemaakt. Voordat een kruising gemaakt gaat worden, denkt een veredelaar goed na over welke ouders er gekruist gaan worden. Deze kruising wordt in de boomgaard uitgevoerd, door zelf een bloem te bestuiven. Als deze bloem goed bestoven is dan ontwikkelt zich er een vrucht. De pitten die uit deze vrucht komen, worden gedroogd en uitgezaaid. De plantjes die daaruit komen noemen we zaailingen. Vaak heeft een veredelaar ieder jaar een paar duizend nieuwe zaailingen. Hieruit moeten alleen de zaailingen overblijven die het best zijn. Door negatieve selectie (iets afkeuren op basis van één of meerdere negatieve eigenschappen) wordt een groot percentage afgekeurd.

De beste zaailingen blijven 2 jaar staan. Daarna wordt van iedere zaailing een boom gemaakt. De zaailing wordt dan op een onderstam gezet (enten). Deze bomen worden in de volle grond geplant en vervolgens start het CGO. Het eerste jaar worden de vruchten van deze bomen afgehaald, zodat ze goed vegetatief kunnen groeien. De vruchten uit het tweede jaar worden beoordeeld op uiterlijk en smaak. Alle bomen waarvan de vruchten tegenvallen worden gerooid en niet verder gevolgd. De bomen met een goede groei en goede vruchten worden langer gevolgd. Als het na een aantal jaren echt een heel goede selectie blijkt te zijn, dan worden van deze boom meerdere bomen gemaakt. Deze bomen worden dan nog verschillende jaren bekeken op het eigen perceel. Dit zijn de selecties die de veredelaar ook graag op andere plaatsen en eventueel in andere landen wil laten toetsen.

\subsection{Doel}

In algemene zin heeft het CGO tot doel relevante informatie te verzamelen van veredelaars of raseigenaren en hun rassen te toetsen onder onze klimaatcondities. Genotypen die voldoen aan het op te stellen zoekprofiel worden geïmporteerd, voorzien van de juiste juridische documenten en eventueel in quarantaine gebracht bij de Naktuinbouw. Indien geen bomen beschikbaar zijn vindt opkweek plaats tot 2 jarige bomen. $\mathrm{Na}$ aanplant en conform de best mogelijk teeltwijze komen de genotypen in de onafhankelijke toetsing.

De algemene doelen van het CGO programma fruitgewassen van Wageningen University \& Research (WUR) zijn kort samengevat:

- Het in beeld brengen van meest interessante rassen voor teelt onder Nederlandse klimaatcondities

- Borgen van $100 \%$ onafhankelijke beoordeling van nieuwe rassen.

- Kansen bieden aan gehele fruitketen (vruchtboomkwekers, fruittelers, handelshuizen, consumenten en faciliterende industrie/diensten).

- Werken aan de duurzaamheidsopgave ten aanzien van intrinsieke weerbaarheid (resistenties en/of veldtoleranties) waardoor de fruitketen minder afhankelijk wordt van pesticiden.

- Het op onafhankelijke wijze cijfers genereren leidt tot inzicht voor productprofilering en zorgvuldig afgewogen marktintroducties. 
Door de rassen onafhankelijk te toetsen biedt het CGO een duidelijke meerwaarde voor veredelaars en ras eigenaren. Dit verhoogt de kans op instroom van potentieel hoogwaardig enthout van nieuwe genotypen. Uitbreiding van appel peer en pruim naar walnoot en hazelnoot versterkt het CGO programma van WUR, maar maakt het voor de nieuwe gewassen ook kosten efficiënter.

In de volgende paragrafen worden de activiteiten beschreven (in willekeurige volgorde) die nodig zijn in het geval dat het CGO wordt uitgebreid met de gewassen walnoot en hazelnoot.

\subsection{Bescherming genetisch materiaal en raszuiverheid}

In CGO staat de soortechtheid van het te toetsen en beoordelen plantmateriaal voorop. Dit vormt niet alleen de basis voor dit onderzoek, maar ook voor het in de handel brengen van nieuwe soorten door de desbetreffende eigenaar. Komt de naam van de werkelijke soort en de naam waaronder het in toetsing is niet overeen, dan kunnen hiervoor geen beschrijvingen worden gemaakt die openbaar worden. Er zijn in de handel erg veel oorzaken waardoor hetzelfde plantmateriaal onder verschillende namen wordt aangeboden. Het kan zijn dat rassen in verschillende regio's van oudsher een andere naam kregen. Het kan gaan om menselijke fouten in schrijfwijze enzovoort, maar ook om oneigenlijk verkregen plantmateriaal dat onder een andere naam of zonder naam in het handelsverkeer wordt gebracht.

Voor onafhankelijke toetsing binnen dit CGO werk wordt ernaar gestreefd om zoveel mogelijk rechtstreeks te werken met de bron, dat wil zeggen de eigenaar van de kruisingen. Hiermee wordt een testovereenkomst aangegaan. Het te toetsen materiaal wordt onder veldcode aangeplant. Voor oude vrije rassen geldt dat het materiaal wordt betrokken van gerenommeerde onderzoeksinstellingen en sortimentstuinen. Zoveel mogelijk dient verwarring te worden voorkomen. Materiaal dat via kwekers en het handelsverkeer in het CGO programma wordt gebracht zal als zodanig worden benoemd in de database. Voor de toekomst heeft dat laatste beperkte waarde voor het onderzoek.

Nieuwe genotypen van veredelaars vertegenwoordigen een grote financiële waarde. Daarom wordt bij CGO voor ieder nieuw genotype een Material Transfer Agreement (MTA) opgesteld en getekend. Hierin staan de rechten en plichten van de raseigenaar en de tester, Wageningen University \& Research, beschreven.

Van oudsher worden noten, evenals appel en peer, veelal geënt op zaailing onderstammen. Voor walnoot zijn ook enkele geselecteerde en via weefselkweek vermeerderde onderstammen beschikbaar. Er zijn ontwikkelingen richting intensivering van de notenteelt. Daarnaast zijn voor hazelnoot en walnoot combinaties mogelijk die de productie en efficiëntie kunnen verhogen, oogst kan vergemakkelijken en de gevoeligheid voor late nachtvorst kunnen verkleinen.

Voor het CGO is het belangrijke dat de proefpercelen uiteraard geschikt zijn voor de teelt van walnoot en hazelnoot. Daarnaast is het zeer belangrijk dat de locatie goede bescherming biedt voor het plantmateriaal dat aan WUR voor testen wordt aangeboden.

\subsection{Internationale inbedding en internationaal netwerk}

Het European Fruit Research Institutes Network (EUFRIN) heeft een Working Group Nut (WGN) die zich richt op nieuwe innovaties in onderzoek en productie van walnoot, amandel, hazelnoot, kastanje en pistachenoten. De WGN verenigt de Europese onderzoekers die zich bezighouden met notenteelt. Veredelaars, plantenpathologen, plantenfysiologen, voedingswetenschappers en andere onderzoekers die onderzoek doen naar de productie van uitgangsmateriaal, microvermeerdering, ziekteverwekkers, insecten, evaluatie van cultivars, onderstammen, boomgaardsystemen, naoogst en marktwaarde hebben zitting in de WGN. De WGN is geïnteresseerd in nieuwe tendensen en resultaten van de leden. Resultaten van onderzoek worden onderling gedeeld. Tevens is het bij uitstek een platform om voor het Nederlandse CGO het netwerk op te bouwen. WUR - Open teelten is lid van het EUFRIN netwerk. 


\section{Literatuur quick scan walnoot (Juglans regia)}

\subsection{Inleiding}

Tot de jaren negentig van de twintigste eeuw is er op het Fruitteelt Proefstation te Wilhelminadorp $1^{\text {ste }}$ fase rassenonderzoek (Cultuur en Gebruikswaarde Onderzoek) uitgevoerd aan walnoot en hazelnoot. De rassenlijst die dateert uit 1999 geeft de rassen weer die het beste gedijen onder de toenmalige Nederlandse klimaatomstandigheden.

Deze quick scan geeft kort de meest veelbelovende ontwikkelingen weer, zowel op het gebied van rassen en onderstammen, ontwikkelingen in intensivering van de teelt en relevante raskenmerken als bloeitijdstip, bestuiving en vermeerderingsmethoden waarover sinds 1990 in de wetenschappelijke literatuur is gerapporteerd. Deze quick scan beperkt zich alleen op de walnoot. De Nederlandse Notenvereniging werkt aan een overzicht voor hazelnoot. Dit rapport zal in de loop van 2020 verschijnen.

\subsection{Aanpak}

Met de zoekmogelijkheden van de bibliotheek van Wageningen University \& Research is een quick scan uitgevoerd naar nieuwe rassen waarover sinds de jaren negentig van de twintigste eeuw is gepubliceerd. Op basis van de samenvattingen van deze artikelen is een selectie gemaakt.

Specifiek is gezocht op:

- Nieuwe rassen sinds 1990 (sinds stop CGO Wilhelminadorp)

- Nieuwe onderstammen sinds 1990

- Bloeitijdstippen (fenologie)

- Bestuiving (zelf bestuivend of niet)

- Voor- en nadelen weefselkweek ten opzichte traditionele vermeerderingsmethoden

Via een zoekopdracht op internet is een lijst opgesteld van in Nederland beschikbare walnootrassen. Deze lijst is waarschijnlijk niet compleet maar dekt wel het grootste gedeelte.

\subsection{Resultaten walnootrassen}

Er worden op dit moment door gespecialiseerde boomkwekers circa 50 walnootrassen geteeld en aangeboden. Daarvan zijn op basis van het CGO Wilhelminadorp (rassenlijst 1999) 6 walnootrassen geschikt en 45 rassen zijn niet eerder onafhankelijk getoetst (Bijlage 1).

In Bijlage 2 staan de walnootrassen waarover na 1990 is gepubliceerd. In deze bijlage staat ook de herkomst vermeld. Een bestaand overzicht is aangevuld met een groot aantal 'nieuwe' rassen, waarvan de meeste nog niet in Nederland beschikbaar zijn. In de wetenschappelijke literatuur wordt de juridische status vaak niet vermeld. Soms wordt vermeld dat commercialisatie is gestart, van de meeste rassen moet worden aangenomen dat de rassen nog in onderzoek zijn.

\subsection{Nieuwe onderstammen voor Juglans regia}

Traditioneel worden walnoten uit zaailingen verkregen en geteeld. Er wordt sinds mensenheugenis tevens geënt op zaailing Juglans of ook op meer of minder heterogene zaailing selecties van Juglans regia. Een bekende oude onderstam betreft Paradox, of zaailingen van de soort Juglans hindsii. De 
drijvende kracht achter de ontwikkeling van onderstammen voor walnoten is de oplossing voor specifieke problemen die vaak verband houden met de aanwezigheid van bodemgebonden ziekten of plagen of de noodzaak van aanpassing aan lokale groei omstandigheden. In deze quick scan is gekeken naar de ontwikkelingen na 1990 op het gebied van geschikte onderstammen voor walnoot. In tabel 1 zijn een aantal eigenschappen van nieuwe onderstammen samengevat .

Tabel 1 Recent beschreven nieuwe onderstammen voor Juglans regia.

\begin{tabular}{|c|c|c|c|c|}
\hline Handelsnaam & Herkomst & $\begin{array}{c}\text { Belangrijkste } \\
\text { selectiecriterium }\end{array}$ & Kruisingsouders & Bron \\
\hline \multirow[t]{2}{*}{ Manregian } & Californië & & & \\
\hline & & & & McGranaham, 2005 \\
\hline Portval & Roemenië & Diverse teeltkundige & 26B:VL & Achim et al., 2007a \\
\hline \multirow[t]{2}{*}{ PX1 } & Californië & Resistent tegen & kloon van Paradox J. microcarpa x J.regia & Connell et al., 2010 \\
\hline & & Phytophthora & & \\
\hline Trinta & Californië & Zwakkere groei dan PX1 & & Connell et al., 2010 \\
\hline \multirow[t]{2}{*}{ VX 211} & Californië & Tolerant voor nematoden $\mathrm{E}$ & Erg groeikrachtig J. hindsii $\times$ J. regia & Leslie \& \\
\hline & & & & McGranaham, 2014 \\
\hline Waterloo & Californië & & & Connell et al., 2010 \\
\hline JinRS-2 & China & vorstresistentie & & Wang et al., 2014b \\
\hline JinRS-3 & China & vorstresistentie & & Wang et al., 2014b \\
\hline \multirow[t]{2}{*}{ Secular R-M } & & & Getest in & Achim et al., 2007b \\
\hline & & & Roemenië & \\
\hline \multirow[t]{2}{*}{ Tg. Jiu 1} & & & getest in & Achim et al., 2007b \\
\hline & & & Roemenië & \\
\hline
\end{tabular}

Naktuinbouw publiceert lijsten van de rassen (inclusief onderstammen) die in Nederland geregistreerd zijn en/of kwekersrecht hebben (Hoffman, 2018). Geen van de in Tabel 1 vermelde onderstammen komt op de meest recente lijst van de Naktuinbouw voor en zijn dus waarschijnlijk nog niet in Nederland beschikbaar. De onderstammen uit Tabel 1 hebben zeker potentie voor toepassing in Nederland, zowel in een walnotenboomgaard als in agroforestry teeltsystemen. Hiervoor is wel nader onderzoek nodig.

\subsection{Fenologie}

Over dit onderwerp zijn 80 wetenschappelijke publicaties gevonden. Geen van deze publicaties geeft makkelijk te gebruiken overzichten met bloeitijdstippen per ras. Wel wordt in verschillende teelt regio's praktijkonderzoek uitgevoerd om na te gaan of wel/geen kruisbestuivers nodig zijn. Oosterbaan (2015) geeft voor de in Nederland bij kwekers verkrijgbare rassen het mannelijke en vrouwelijke bloeitijdstip aan en geeft ook aan of er een bestuiver nodig is. De Nederlandse notenvereniging voert momenteel een inventarisatie uit bij haar leden met walnoten plantages. De mannelijke en vrouwelijke bloeitijdstippen en de opbrengsten worden gedurende meerdere jaren genoteerd.

In Roemenië is in 2010 een uitgebreide rassenevaluatie afgerond (Botu et al., 2010). Er werden binnen de getoetste rassen belangrijke verschillen waargenomen met betrekking tot de resistentie tegen de bacteriële infectie Xanthomonas campestris pv. juglandis. Zuiver Roemeense rassen droegen veel minder vruchten dan de geïntroduceerde buitenlandse rassen. De rassen met de laterale bloei bloeiden van eind april tot midden mei. In het $12 \mathrm{e}$ productiejaar varieerden de opbrengsten tussen 1,5 en 2,6 t / ha in het geval van terminale dragende rassen en van 1,7 tot 4,1 t / ha voor de laterale dragende exemplaren. De beste rassen onder de plaatselijk ecologische omstandigheden van het gebied Oltenia in Noordwesten van Roemenië bleken te zijn: 'Valcor' en 'Jupanesti' (einddrager), Hartley (eind en laterale dracht) en Vina en Ferjean (laterale dracht) (Botu et al., 2010). 
In Californië is onderzoek uitgevoerd naar de bestuivingsdynamiek en de stuifmeelstroom in walnotenboomgaarden (Polito et al., 2006). De doelstelling van deze studie was het documenteren van effectieve bronnen van stuifmeel van de twee rassen die in de boomgaard aanwezig waren, door stuifmeel-afkomst van noten te bepalen, de bloeifenologie te beschrijven en aanbevelingen te ontwikkelen over de eisen waar bestuivers in een walnotenboomgaard aan moeten voldoen. De resultaten toonden veel hoger dan verwachte niveaus van stuifmeel-afstammelingen afkomstig van bronnen van ver buiten de boomgaard. Een heel hoog percentage bomen werd bevrucht door bomen die bovenwinds in het landschap aanwezig waren en niet uit de eigen boomgaard (Polito et al., 2006). Walnoot kenmerkt zich door een aanzienlijke variatie in de jaarlijkse bloeiperiode. Dat maakt het lastig algemeenheden te beschrijven of te tabelleren over bestuiving en kans op goede vruchtzetting. Diversiteit in de aanplant met bewezen goede bestuivers geeft zeker met een grilliger wordend klimaat verhoogde kans op jaarlijks goede dracht en oogst .

Evaluatie van sommige rassen onder eigen klimatologische omstandigheden blijft nodig en gegevens uit andere klimaten zijn niet zonder meer vertaalbaar. Deze evaluaties dienen gericht te zijn op het selecteren van walnootcultivars met geschikte biologische en pomologische kenmerken bij huidige en eventueel te extrapoleren toekomstige omstandigheden. Uit economisch oogpunt is het zinvol een lijst op te stellen van late nieuwe rassen met laterale dracht eventueel in combinatie met dwerggroei. Hierdoor kan de plantdichtheid per ha mogelijk verhoogd worden.

\subsection{Voor- en nadelen in vitro ten opzichte traditionele vermeerderingsmethoden}

In vitro vermeerdering wordt momenteel gezien als beste hulpmiddel om de grootste fundamentele teeltproblemen op te lossen, zoals de snelheid van de vermeerdering om een nieuw ras op grote schaal te kunnen introduceren en het verkrijgen van grote partijen ziektevrije planten met een hoge mate van uniformiteit. Gedurende de laatste paar jaren zijn verschillende methoden ontwikkeld voor in vitro vermeerdering van walnoot. Yadav \& Chandra (2015) beschrijven hun ervaringen met in vitro vermeerdering van walnoot en geven aan dat dit perspectieven biedt voor de toekomst.

In deze quick scan is gekeken of er studies te vinden zijn waarin de groei van plantmateriaal uit weefselkweek vergeleken is met de groei van gangbaar plantmateriaal.

In totaal werden 463 artikelen gevonden over vermeerdering van walnoot sinds 1990 . Deze studies gaan voornamelijk over de methodologie van de vermeerdering, waarbij het overgrote gedeelte over de technieken van in vitro vermeerdering gaan. Geen enkele studie werd gevonden met vergelijkingen van de groei tussen in vitro en traditionele opgekweekt plantmateriaal.

\subsection{Aanknopingspunten voor intensivering van de productie}

Naast de hierboven in paragraaf 3.4 genoemde nieuwe selectieprogramma's voor onderstammen zijn er enkele veelbelovende nieuwe ontwikkelingen, met name uit de periode van na 2006:

- Selectie van dwergwalnoten (Wang et al., 2014);

- Selectie van walnoten op basis van internodiënlengte;

- Selectie op basis van laterale dracht (Rouskas \& Zakynthinos, 2001; Korac, 1993);

- En combinaties van deze criteria. (Vahdati et al., 2014, 2018);

- Verder wordt er sinds ongeveer 10 jaar op grotere schaal geëxperimenteerd met heggenteelt. Hierbij worden snoeiregime en snoeiwijze gevarieerd (Aletà et al., 2005; Ramos et al., 1992; Olson et al., 2005).

Standaard zaailingen van walnoot hebben een lange juveniliteit, wat inhoudt dat het lang duurt voordat de bomen noten gaan dragen. Er zijn genotypen van walnoot die vroegrijp zijn en een korte fase van juveniliteit hebben. Deze genotypen hebben meestal een clusterdragende bloeiwijze en lage 
groeikracht. Dergelijke dwerg genotypes kunnen niet alleen als een onderstam worden gebruikt maar ook in veredelingsprogramma's voor het kweken van walnoten om de vegetatieve volwassen fase te verkorten, maar ook potentieel hebben voor het aanplanten in een hogere dichtheid dan de gebruikelijke 100 bomen/ha. Daarom zijn deze genotypen van walnoot ideaal materiaal voor genetici om de genen te vinden die betrokken zijn bij vroegrijpheid, groei, bloei, gemakkelijke beworteling en andere waardevolle eigenschappen. Een selectieprogramma om deze eigenschappen te gebruiken in boomgaardsystemen met hoge plantdichtheid wordt uitgevoerd in Iran (Vahdati et al., 2018).

Er wordt op diverse plaatsen geëxperimenteerd met haagboomgaarden van walnoot. In hoeverre deze teeltsystemen ook al commercieel worden toegepast staat niet vermeld. Het gaat om experimenten waarbij meerjarige experimenten zijn aangelegd met plantverbanden van $7 \mathrm{~m} \times 5 \mathrm{~m}$ (285 bomen/ha) of $7 \mathrm{~m} \times 3,5 \mathrm{~m}$ (408 bomen/ha). De 12 jaar durende proef liet zien dat het gemakkelijk is om snel een hoge productie te krijgen als geschikte rassen worden gebruikt in een dergelijk plantsysteem. Twee essentiële kenmerken lijken vereist voor haagaanplanten: hoog lateraal dragend, gecombineerd met een lage tot middelmatige groeikracht (Ninot et al., 2005). Ook wordt geëxperimenteerd met de frequentie van de snoei van de hagen, waarbij in Spanje 2-3 jarige interval geschikt lijkt voor een aantal hoofdrassen. Een interval langer dan 3 jaar leidde tot te veel "zelf-overschaduwing" en productieremming (Ramos et al., 1992; Aletà et al., 2005; Ninot et al., 2000). Bij een

haagplantsysteem speelt de keuze van het ras een grote rol bij de productie. 'Chico' lijkt geschikt te zijn voor het haagplantsysteem, terwijl 'Vina' moeite heeft om de groei en de grootte van de noot onder dergelijke omstandigheden te handhaven. Andere rassen, zoals 'Chandler', 'Howard', 'Tulare', 'Lara' en 'Fernor', worden ook aangehaald als geschikt voor aanplant in een haagboomgaardsysteem. Jaarlijkse en tweejaarlijkse mechanische snoei van heggen van Chico-walnoot werd vergeleken met hand gesnoeide standaardbomen over een periode van 6 jaar. De opbrengsten waren groter van hagen die jaarlijks aan één kant werden gesnoeid dan van hagen die jaarlijks aan weerszijden of van met de hand gesnoeide bomen. De grootte van de noten is over het algemeen omgekeerd evenredig met de opbrengst (Aletà et al., 2005).

\subsection{Laterale dracht en dwerggroei}

Het lateraal dragen is een veelbelovende onderzoekslijn die kan leiden tot boomgaarden met een hogere plantdichtheid dan de gebruikelijke 100 bomen/ha. Grieks onderzoek geeft aan dat S1-A, S34A, S1-B, S4-B en S14-B veelbelovende nieuwe selecties zijn met een hoge mate van laterale dracht (Rouskas \& Zakynthinos, 2001).

In China wordt geselecteerd op dwergroei bij walnoot. Als resultaat van dit werk in het afgelopen decennium zijn zes dwergnootnootcultivars geselecteerd, 'Xinwen 609', 'Xinwen 724', 'Xinwen 908', 'Xinwen 915', 'Xin 916' en 'Xinwen 917' (Wang et al., 2014a).

\subsection{Suggesties voor een eerste aanplant met relatief recent ontwikkelde rassen}

De afgelopen jaren zijn bij telers en bij WUR Open Teelten (locatie Randwijk) beperkte aantallen walnootrassen aangeplant waarvan nog relatief weinig bekend is onder onze klimaatcondities. In bijlage 3 is een lijst toegevoegd met rassen die voor een dergelijke evaluatie in aanmerking komen.

Belangrijke criteria zijn:

- Hoge potentiele productie;

- Goede kwaliteit (olie/smaak);

- Laterale dracht;

- Late bloei;

- Dwerggroei;

- Weinig ziekte- en plaaggevoelig;

- Geen rassen die al getoetst zijn in Nederland):

- Geen sierbomen 
- Rassen die bij de Naktuinbouw in het toelatingstraject zitten.

Mogelijk is er al meer informatie verzameld bij de leden van de Notenvereniging, waardoor bijlage 2 kan worden aangevuld of opgeschoond op basis van opgedane ervaring.

\subsection{Volgende stappen}

Op basis van de ontwikkelingen sinds 1990 lijken voor de Nederlandse notenteelt de volgende stappen zinvol. Het opstarten van Cultuur en Gebruikswaarde Onderzoek walnoot gericht op een selectie van walnoten die al in Nederland aanwezig zijn en niet eerder onderzocht zijn, is een voor de hand liggende en wenselijke onderzoekslijn. De lijst uit bijlage 2 met momenteel beschikbare rassen zou kunnen worden gebruikt als groslijst. Het Nederlandse hoofdras 'Broadview' zou kunnen dienen als een geschikte referentie. Leden van de Nederlandse notenvereniging kunnen het beste aangeven in welke rassen zij het meeste vertrouwen hebben op basis van slagingspercentages en eerste ervaringen in de teelt.

Gezien de klimaatsverandering en de toenemende grilligheid van het klimaat lijkt het verstandig regio's met de meest milde winters te selecteren voor deze veldproeven, waarbij Zeeland voor de hand ligt. Onderzoekslijnen met een langere scope zijn ook wenselijk. Deze zouden gericht moeten zijn op het samenstellen van een groslijst van lateraal dragende rassen, waaruit op basis van de reeds bekende raseigenschappen een selectie zou kunnen worden gemaakt. Hetzelfde geldt voor rassen met een gedrongen groei of dwerggroei. 


\section{Teeltsystemen}

\subsection{Inleiding teeltsystemen}

Zoals eerder vermeld is het areaal hazelnoten en walnoten in Nederland op dit moment beperkt $(<100$ ha) met als gevolg dat er ook weinig informatie beschikbaar is over optimale teeltomstandigheden. In het algemeen is de plantdichtheid afhankelijk van de groeiomstandigheden en de voorkeur van de teler. In gebieden met slechte omstandigheden is een grotere plantafstand gebruikelijk dan in gebieden met betere omstandigheden.

Net zoals bij andere boomgewassen, zoals appel en peer, wordt er gestreefd naar intensivering van het teeltsysteem om de opbrengst per oppervlakte eenheid te verhogen (Wertheim en Goedegebure, 1988). Door meer bomen per ha aan te planten, wordt de optimale omvang van de boomkroon per ha sneller bereikt en daardoor worden maximale opbrengsten in sommige cultivars sneller bereikt (Ellena et al., 2012). Doel is de stichtingsperiode (zie Hoofdstuk 7) te verkorten. Dit verbetert het economisch rendement. Een hogere plantdichtheid zorgt echter ook voor hogere initiële kosten. Daarnaast is nodig om na een aantal jaren te dunnen, soms tot 50\%, om te voorkomen dat de bomen teveel met elkaar concurreren (Tous et al., 1992). Naast het verhogen van de plantdichtheid kunnen ook de in Hoofdstuk 3 beschreven lateraal dragende rassen een bijdrage aan leveren aan een verbeterd economisch rendement.

\subsection{Hazelnoot}

Er bestaan verschillende systemen voor het telen van hazelnoten, elk geschikt voor verschillende behoeften en voorkeuren van de teler. De belangrijkste keuzes betreffen de boomvorm en plantdichtheid. De verschillende boomvormen zijn o.a. enkele stam vaasvorm, struik, V-vormige haag en meer experimenteel; verticale vorm en haagvorm (Germain en Sarraquigne, 1996; Rutter en Shepard, 2002; Tous, 2004). Plantdichtheid is over het algemeen afhankelijk van de groeiomstandigheden, cultivars en beschikbare machines. Plantdichtheid kan ook dynamisch zijn; geplant met een hoge dichtheid en later gedund tot een lagere dichtheid, wanneer de bomen met elkaar concurreren. Een tussenruimte van 2,7 x 5,5 m wordt bijvoorbeeld gedund tot 5,5 x 5,5 m (Olsen, 2013) of 2,5 × $4 \mathrm{~m}$ tot $5 \times 4 \mathrm{~m}$ (Bignami et al., 2004).

Er zijn weinig veldproeven met hazelnoten uitgevoerd in Nederland. Er zijn dan ook geen gegevens bekend over geschikte cultivars en optimale dichtheid voor de verschillende regio's. Eerder onderzoek werd uitgevoerd met een tussenruimte van 4,5 x 2,75 m (807 bomen/ha) en 4,5 x $2 \mathrm{~m}$ (1111 bomen/ha), maar verschillende cultivars werden gebruikt voor de twee plantdichtheden, dus vergelijkingen kunnen niet worden gemaakt (Wertheim en Goedegebure 1988).

Desondanks kan informatie uit andere regio's inzicht geven in optimale plantdichtheden. In Figuur 4.1 is het effect van verschillende plantdichtheden op de opbrengsten van verschillende cultivars te zien in Italië. Bij een van de cultivars (104F) is het verschil in opbrengst tussen 666 en 1666 bomen/ha marginaal. Voor de cultivar Daria stijgt de opbrengst met ongeveer 20\% en voor cultivar 101 heeft de plant met hoge dichtheid 3 keer de opbrengst van de beplanting met lage dichtheid. Hier valt op dat de optimale plantdichtheid afhangt van de gebruikte cultivars. Plantages met hoge dichtheid (in heggen) vereisen ook verschillende snoeiwerkzaamheden en training (ontwikkeling van een gewenste boomvorm), en bijgevolg toont deze studie de effecten van zowel snoei en plantdichtheid op de opbrengsten van hazelnoten. 


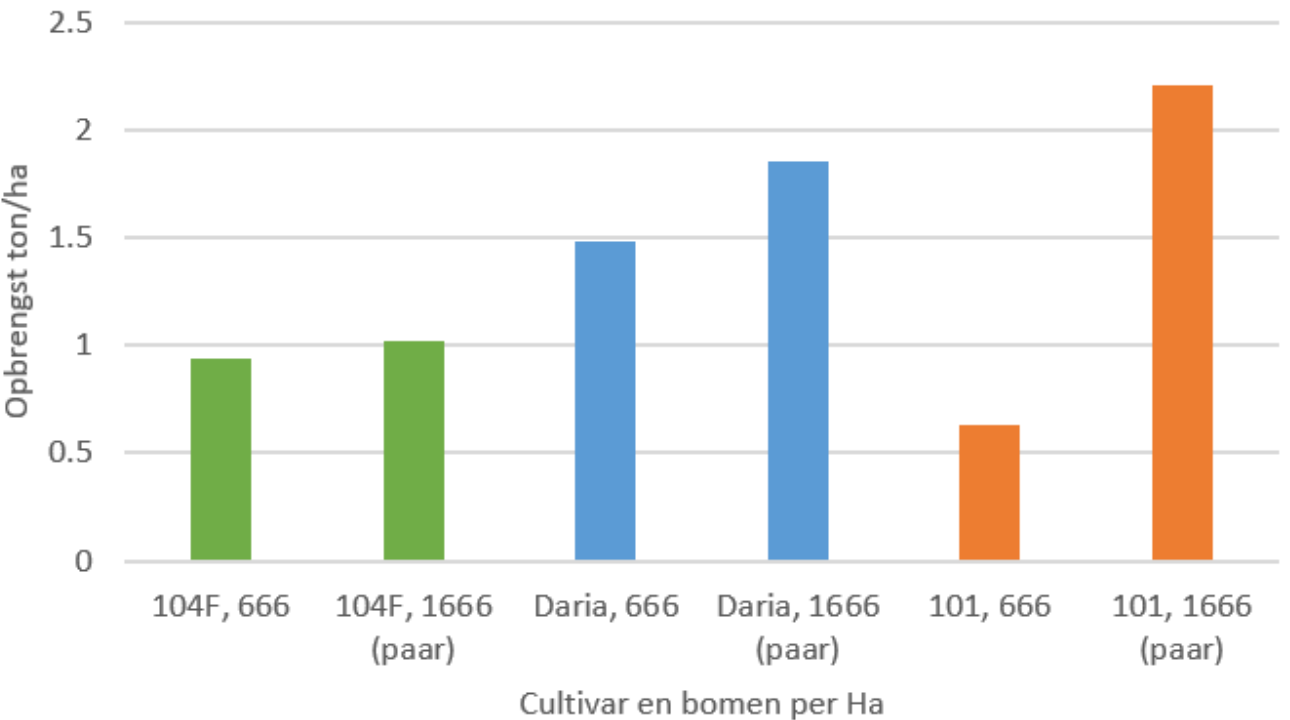

Figuur 4.1 Gemiddelde hazelnootopbrengst tussen 7 en 11 jaar na aanplant (Cuneo, Italië) met 666 of 1666 bomen/ha (op basis van Me et al., 2000).

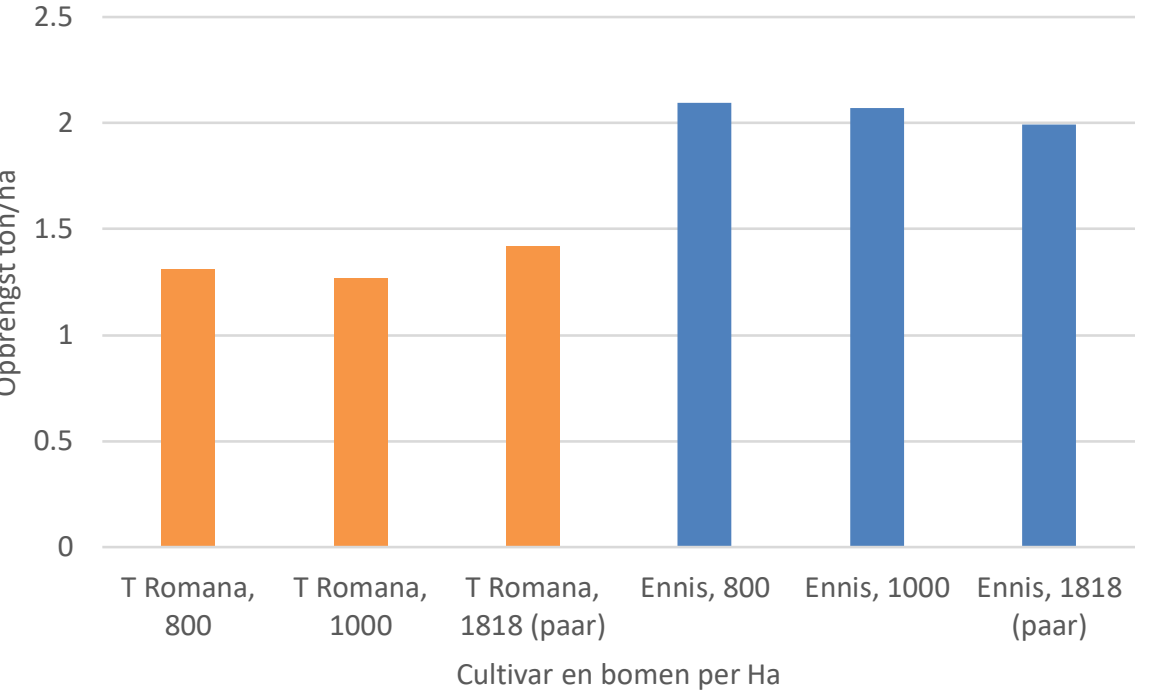

Figuur 4.2 Gemiddelde hazelnootopbrengst van 3 - 12 jaar oude aanplant van twee cultivars met 800, 1000 en 1818 bomen per ha (Gironde, Frankrijk).

In Figuur 4.2 is het effect van drie verschillende plantdichtheden te zien op twee hazelnoten cultivars in Frankrijk. De gemiddelde opbrengsten van 3 - 12 jaar oude aanplant tonen beperkte effecten van het verhogen van de plantdichtheid van 800 bomen/ha tot 1818 bomen/ha voor deze cultivars. Cultivar T Romana heeft een lichte toename in opbrengst, terwijl Ennis een lichte afname geeft bij toenemende plantdichtheden. Gezien de hogere initiële kosten van boomgaarden met een hogere dichtheid, is waarschijnlijk dat onder deze omstandigheden de optimale dichtheid voor beide cultivars ligt op ongeveer 800 bomen per ha. Wat ook in aanmerking moet worden genomen, is dat beplantingen met een hogere dichtheid vaak op een bepaald moment moeten worden gedund. Zoals weergegeven in Tabel 2, zal in veel gevallen tot $50 \%$ van de oorspronkelijke aanplant worden verwijderd om ruimte te maken voor de overgebleven bomen. Zie bijlage 4 voor meer informatie over cultivaropbrengsten met verschillende dichtheden. 


\begin{tabular}{lllll}
$\begin{array}{l}\text { Plantafistand bij } \\
\text { aanplant }(\mathrm{m})\end{array}$ & $\begin{array}{l}\text { Bomen/ha bij } \\
\text { aanplant }\end{array}$ & $\begin{array}{l}\text { Plantafistand na } \\
\text { dunnen }(\mathrm{m})\end{array}$ & Bomen/ha na dunnen \\
$5 \times 2.5$ & 800 & $5 \times 5$ & 400 & (Germain, 1986) \\
\hline $5 \times 3$ & 667 & $5 \times 6$ & 333 & (Sarraquigne, 2004) \\
\hline $6 \times 3$ & 556 & Niet vermeld & Niet vermeld & (Sarraquigne, 2004) \\
\hline $5 \times 4$ & 500 & Niet vermeld & Niet vermeld & (Sarraquigne, 2004) \\
\hline $2.7 \times 5.5$ & 673 & $5.5 \times 5.5$ & 331 & (Olsen, 2013) \\
\hline $2.5 \times 4$ & 1000 & $5 \times 4$ & 500 & (Bignami et al., 2004) \\
\hline $5 \times 2.4$ (pairs) & 1667 & & 833 & (Tous et al., 1992) \\
\hline
\end{tabular}

\subsection{Walnoot}

Het plantsysteem van walnoten is afhankelijk van de doelen en middelen van de teler en de locatie. Traditioneel werden noten gekweekt in vrij extensieve systemen en soms gecombineerd met productie van notenhout. In dergelijke gevallen was het vrij gebruikelijk om dichtheden te hebben van $12 \times 10$ m, $12 \times 12$ m en zelfs $15 \times 15$ m (Wertheim, 1981). Er zijn echter zeer intensieve systemen van $7 \times$ 4,7 $\mathrm{m}$ en $7 \times 3,5 \mathrm{~m}$ getest in de Verenigde Staten (Ramos et al., 2001) en systemen met plantdichtheden van $7 \times 7$ en $8 \times 8 \mathrm{~m}$ worden gevonden in Frankrijk (Wertheim, 1981). In boomgaarden met hogere dichtheden is snoeien, dunning, of beide, vereist om de productiviteit van de boomgaard te behouden. Dit is met name van belang voor cultivars die noten dragen op het einde van een tak (terminale dragende rassen). Bomen kunnen geleidelijk worden gedund ('Whiskbrooming') of met eenmalige verwijdering (Ramos, 1995; Olson et al. 1995). Bij geleidelijke verwijdering worden de gekozen bomen elk jaar gesnoeid om ruimte te creëren voor de bomen die zullen blijven en uiteindelijk worden ze volledig verwijderd. Op deze manier wordt het opbrengstverlies bij het verwijderen van de bomen verminderd.

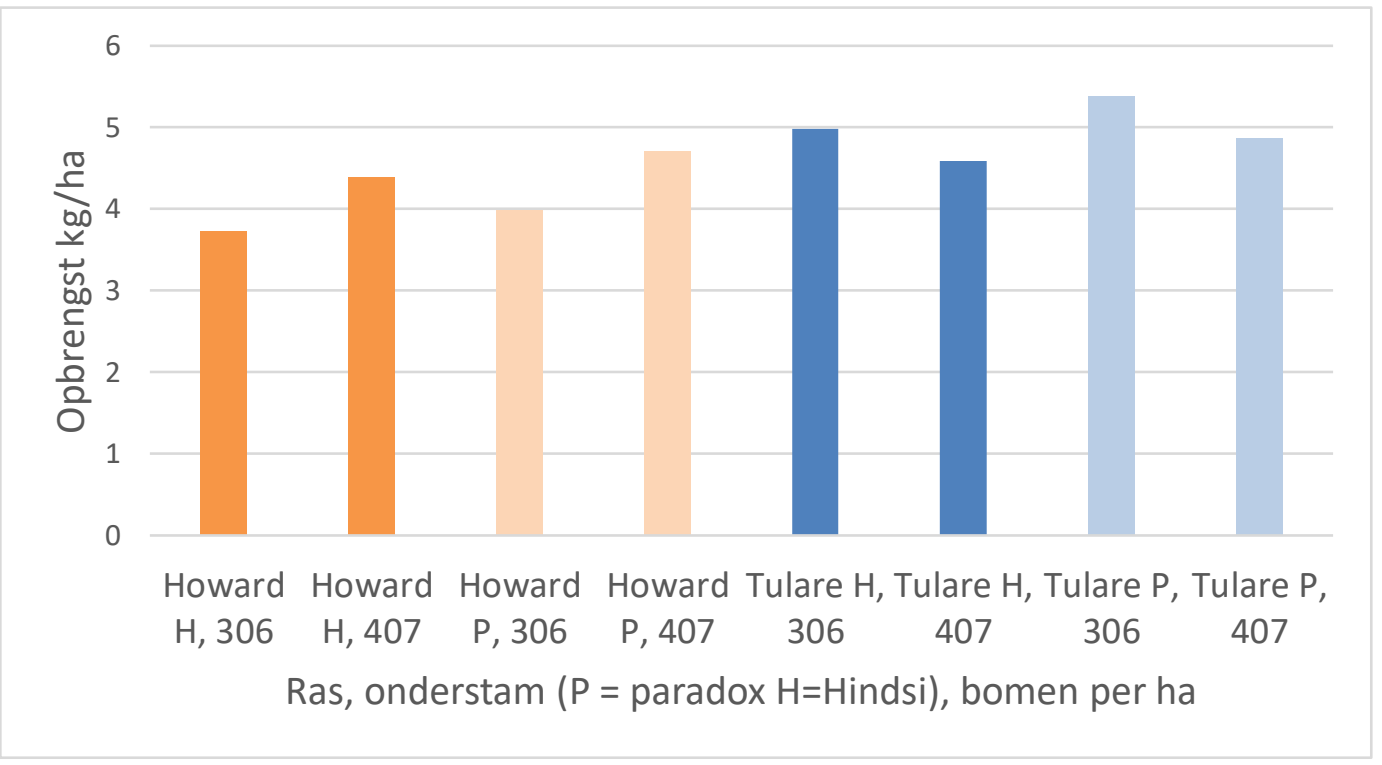

Figuur 4.3 Gemiddelde walnootopbrengst tussen 5 en 9 jaar na aanplant (VS, California) met 306 en 407 bomen per ha. Based on Ramos, Kelley et al. (2001).

Momenteel zijn er beperkt gepubliceerde gegevens die de effecten van plantafstand op de opbrengst van walnoten vergelijken beschikbaar. Figuur 4.3 toont de opbrengst van twee walnoot cultivars, op twee verschillende onderstammen, bij 306 bomen/ha en 407 bomen/ha. Dit is een zeer intensieve aanplant voor walnoot. De cultivar Howard geeft hogere opbrengsten bij een plantdichtheid van 407 bomen/ha in vergelijking met 306 bomen/ha voor zowel de Paradox als de Hindsi onderstammen. Omgekeerd presteerde de cultivar Tulare beter bij de lagere plantdichtheid van 306 bomen/ha. Tulare is een zeer krachtig groeiende cultivar en zal dus onderling snel beginnen te concurreren, in vergelijking met de cultivar Howard, die langzamer groeit. Dit laat zien hoe de ideale plantdichtheid 
sterk afhankelijk is van de gebruikte cultivar. Kleinere, minder krachtig groeiende cultivars hebben grotere voordelen van een hoge plantdichtheid bij aanplant. Dergelijke hoge plantdichtheden zijn niet getest in Europa. Meer algemene plantdichtheden zijn te zien in Tabel 3. Verder is een samenvatting van de beschikbare walnootgegevens te vinden in Bijlage 5.

Tabel 3 Plantdichtheden en aantal bomen per ha van walnoten in verschillende plantsystemen (Wertheim, 1981).

\begin{tabular}{lcl}
$\begin{array}{l}\text { Plantafistand bij aanplant } \\
(\mathrm{m})\end{array}$ & Bomen/ha bij aanplant & \\
$7 \times 7$ & 204 & Frankrijk \\
\hline $8 \times 8$ & 156 & Frankrijk \\
\hline $9 \times 8$ & 139 & Frankrijk \\
\hline $11 \times 10$ & 90 & Frankrijk \\
\hline $12 \times 9$ & 93 & Duitsland \\
\hline $10 \times 9$ & 111 & Duitsland \\
\hline $9 \times 7$ & 158 & Duitsland (onderstam: zwarte walnoot) \\
\hline $8 \times 7$ & 178 & Duitsland (onderstam: zwarte walnoot)
\end{tabular}




\section{Koolstofopslag}

\subsection{Theoretisch kader en literatuurstudie koolstofopslag potentieel}

Uitbreiding van de notenteelt in Nederland zou op drie manieren kunnen bijdragen aan klimaatmitigatie; via koolstofvervanging, broeikasgas uitstootvermindering en koolstofopslag (Smith et al., 2013).

\section{Koolstofvervanging}

Koolstofvervanging vindt plaats wanneer niet duurzaam gebruik van koolstof wordt vervangen met meer duurzame producten. Denk aan het vervangen van fossiele brandstof met bio-energie of het gebruik van inlandse houtproducten in plaats beton of staal. Bijgevolg kan er via vermindering van transportkosten en mogelijk van ontbossing klimaatwinst worden geboekt (Smith et al., 2013). Walnotenhout van Nederlandse notenteelt zou als bijproduct op kleine schaal gebruikt worden in bijvoorbeeld de bouw of meubilair voor vervanging van elders onverantwoord gekapt hout (Cutter \& Garret, 1993). Zelfs de wortels van de bomen, rond $25 \%$ van de totale biomassa, hebben grote economische waarde (Cutter \& Garret, 1993; Cambria \& Pierangeli, 2012). Hazelnotenhout is minder geschikt voor commerciële houtproductie en langdurige vastlegging van koolstof na de oogst. Wel kan het dienst doen als brandhout of worden geteeld als energiegewas en zodoende bijdragen aan klimaatmitigatie (Ghaley \& Porter, 2014). Koolstofvervanging is een vorm van netto uitstootvermindering.

\section{Uitstootvermindering}

Uitstootvermindering is afhankelijk van de intensiteit waarmee het productiesysteem beheerd wordt. Koolstofvervanging behelst dus vervanging van een product en uitstootvermindering behelst verduurzaming van de productiewijze. Op walnotengaarden in California bijvoorbeeld zorgen hoog energieverbruik bij irrigatie, bij het oogstproces, het kraken van de noten en het inefficiënte gebruik van bijproducten als energiebronnen, voor een hoge uitstoot van $\mathrm{CO}_{2}$-equivalenten ha-1 $\mathrm{y}^{-1}$ (Marvinney et al., 2014). Deze uitstoot is hoger dan de gemiddelde eenjarige teelt van onder andere durum graan, gerst, maïs, zonnebloem, sojaboon, aardappelen of koolzaad in Europa of Amerika (Kutsch et al., 2010; Stavi \& Lal, 2013). Marvinney et al. (2014) oppert echter ook dat door maatregelen te treffen waarbij al het afval van de boomgaard gebruikt wordt netto een negatieve uitstoot kan worden bereikt (Marvinney et al., 2014). Bovendien wordt verwacht dat energieverbruik voor irrigatie op notengaarden in Nederland een stuk lager uitvalt. Verder kan via vervanging van bijvoorbeeld veeteelt met notenteelt worden bespaard op de uitstoot van methaan $\left(\mathrm{CH}_{4}\right)$, lachgas $\left(\mathrm{N}_{2} \mathrm{O}\right)$ en stikstofmonoxide (NO) (van Bruggen et al., 2014; Mol \& Hilhorst, 2003). Daarnaast zal er na vervanging van een gebruikelijke eenjarige teelt met een notengaard relatief minder bemesting nodig zijn (Szott \& Kass, 1993) en wordt aanwezige $\mathrm{N}_{2} \mathrm{O}$ in het systeem beter gerecycled via het bladafval en de wortels met bijgevolg minder uitstoot van $\mathrm{NO}_{x}$. Aangezien één ton $\mathrm{N}_{2} \mathrm{O}$ overeenkomt met 298 ton $\mathrm{CO}_{2}$-equivalenten, is dit relevant voor de klimaatproblematiek. Verder is deze bijdrage moeilijk te kwantificeren omdat hier mogelijk leakage zal optreden door intensiever landgebruik elders (Lee et al., 2007; Boosten et al., 2018).

\section{Koolstofopslag}

De mate waarin notengaarden kunnen bijdragen aan boven- en ondergrondse koolstofopslag is afhankelijk van verschillende factoren. Denk hierbij aan de plantdichtheid, de soort bomen, de leeftijd van de aanplant, de ligging, het klimaat, het management en het eindproduct (Smith et al., 2013). In dit project lag de focus op de koolstofopslag in Nederlandse notengaarden. Het literatuuronderzoek diende om erachter te komen welke componenten van koolstofopslag relevant waren om te kwantificeren en om de methode voor bemonstering te bepalen. Ook zijn CO2Fix en Yield-Safe bekeken als opties voor modellering van koolstofopslag in de notengaarden. 


\subsection{Koolstofopslag in bovengrondse en ondergrondse biomassa}

Via fotosynthese fixeren planten $\mathrm{CO}_{2}$ in bovengrondse en ondergrondse biomassa. Netto opgeslagen koolstof (C) komt pas weer vrij bij vertering of verbranding van de biomassa. De periode tot ontbinding en uitstoot van koolstof kan door het duurzaam gebruik van hout, maaisel en andere natuurproducten worden verlengd. Een deel van de $\mathrm{CO}_{2}$ komt dus weer vrij, een deel wordt langdurig opgeslagen in houtproducten, en een ander deel komt terecht in de bodem als organisch koolstof (SOC) (zie figuur 5.1).

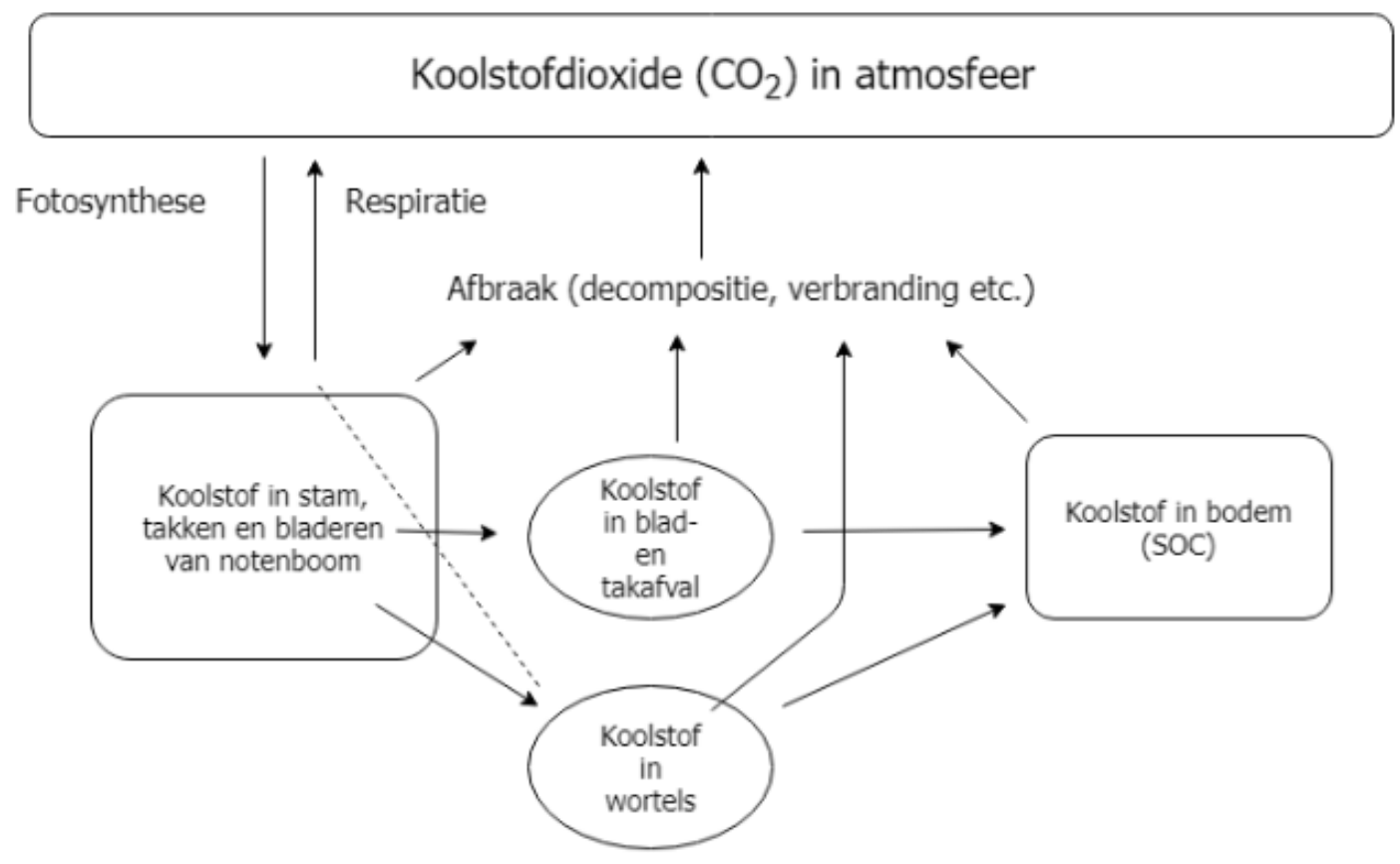

Figuur 5.1 Schematische representatie van versimpelde koolstofcyclus en koolstofopslag in biomassa en bodem.

Meerjarige gewassen, zoals notenbomen, werken de periode en omvang van koolstofopslag in biomassa in de hand omdat ze in tegenstelling tot eenjarige teelten niet jaarlijks grotendeels worden geoogst (Nair et al., 2008; Wauters et al., 2008; Soto-Pinto et al., 2010). In eenjarige teelten komt doorgaans aan het einde van het groeiseizoen al de opgeslagen koolstof weer vrij. Gemiddeld stoten

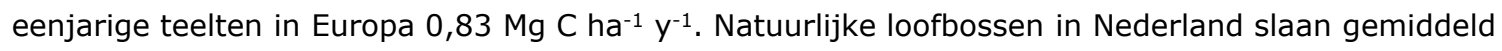
3,2 Mg Cha-1 $\mathrm{y}^{-1}$ op in boven- en ondergrondse biomassa en hebben een gemiddelde koolstofvoorraad van $96 \mathrm{Mg} \mathrm{C}$ ha-1 in boven- en ondergrondse biomassa. Loofbossen zijn dus in staat een significante bijdrage te leveren aan klimaatmitigatie (Arets, 2018). Voor boomgaarden geldt dit ook. Boomgaarden bevatten minder vegetatie en bomen per hectare dan bos maar kunnen relevante hoeveelheden koolstof opslaan in houtige biomassa (Zhang et al., 2017). Hieronder wordt daar voor walnoten- en hazelnotengaarden op ingegaan.

\subsubsection{Koolstofopslag en verschillende bepalingen gebruikt voor walnotenbomen}

Op basis van data uit de literatuur is in tabel 4 en figuur 5.2 en 5.3 een overzicht van koolstofaccumulatiesnelheden en koolstofopslag in staande biomassa van walnotenbomen gepresenteerd. Een normale plantdichtheid voor walnotenbomen is rond de 100 bomen ha- 1 . In de tabel is zichtbaar dat meer bomen per hectare niet per se een hogere koolstofopslag betekent. Tussen een dichtheid van 70 en 110 bomen ha-1 en een leeftijd van 14 tot 18 jaar is de accumulatiesnelheid van koolstof per boom het hoogst - rond de 0,62 tot $3 \mathrm{Mg} \mathrm{Cha}^{-1} \mathrm{j}^{-1}$. Of er sprake is van meer productieve boomsoorten is niet duidelijk.

Walnotenbomen kunnen een productieve levensspanne hebben van meer dan 100 jaar. Maximale koolstofvoorraden zijn sterk afhankelijk van wanneer de bomen geoogst worden. Als de 
walnotenbomen na 50 jaar worden gekapt komt de maximale koolstofvoorraad (geschat op basis van de gemiddelde accumulatiesnelheid uit tabel 4) uit op 69,2 $\mathrm{Mg} \mathrm{C} \mathrm{ha-1}^{-1}$. Dit is minder dan in bos maar een stuk groter dan de verwaarloosbare koolstofvoorraad in biomassa op landbouwgrond. De verschillen in accumulatiesnelheid zijn afhankelijk van de methodiek van de studie en van de specifieke condities die heersten in de boomgaarden. Hieronder wordt hier op deze verschillen ingegaan en worden er getracht lessen uit de benaderingswijzen te trekken voor dit onderzoek en vervolgonderzoek.

Cardinael et al., (2017) mat tien tot twintig bomen in Franse agroforestry-systemen door de stam op te delen in stukken van 1,30 m lengte, de diameter van deze stukken en takken direct groeiend uit de stam te meten en via formules voor het volume van afgeknotte kegels de inhoud van de bomen te berekenen. Gehalte aan koolstof in het hout werd gebaseerd op die in Prunus avium en Juglans nigra, daar er normaliter weinig variatie zit tussen deze langzaam groeiende bomen $\left(462,7-499,7 \mathrm{mg} \mathrm{C} \mathrm{g}^{-1}\right.$ DM; Lamlon and Savidge, 2003). Ook werd er aangenomen dat oude en jonge bomen identieke houtdichtheid en koolstofgehalte hadden. Ondergrondse biomassa werd aan de hand van een formule voor gematigde bossen geschat (Cairn et al., 1997).

$$
\mathrm{RB}=e^{-1.3267+0.8877 \times \ln (A B)+0.1045 \times \ln (\text { Age })}
$$

Hierin is RB de totale biomassa van de wortels ( $\mathrm{Mg} \mathrm{C} \mathrm{ha-1}$ ), AB bovengrondse biomassa ( $M G$ C ha-1), en Age is de leeftijd van de boomgaard (jaren). In de tabel 4 zie je voor Cardinael et al., 2017 de gemiddelde aangroei van koolstof per ha, geschat op basis van de al aanwezige koolstofvoorraad in staande biomassa. Er is geen informatie beschikbaar van het mogelijke effect van het management van de systemen (bemesting etc.).

Jacobs et al., (2009) mat van vijf willekeurige walnotenbomen per gemengde plantage voor houtproductie in Noord-Amerika de basale diameter $(5 \mathrm{~cm}$ boven grond), de diameter op borsthoogte ( $\mathrm{DBH} ; 1,37 \mathrm{~cm}$ boven grond) en de diameter van de kroon. Vervolgens werden bomen geveld om hoogte te meten. Volume van de kroon werd berekend via een formule voor een kegel $(\mathrm{V}=$ $\left.0,2618 D^{2} H\right)$, met $V=$ volume kroon, $D=$ diameter kroon en $H$ is hoogte kroon. Bovengronds werd de boom opgedeeld in twee compartimenten bestaande uit 1) de hoofdstam met hoofdtakken ( $\geq 20 \mathrm{~cm}$ diameter en 2) de overgebleven takken en bladeren. Voor analyse van koolstofgehalte werden monsters genomen van de twee compartimenten. De gemiddelde accumulatiesnelheid in tabel 4 is uitsluitend gebaseerd op de koolstof in de stam en de hoofdtakken en is berekend door de koolstofvoorraad in walnotenbomen per ha te delen door jaren sinds aanplant. Aangezien dit een gemengde plantage betrof en de bomen meer leden aan competitiedruk is deze niet goed te vergelijken met Cardinael et al., (2017) noch met notengaarden, waar de plantdichtheid een stuk lager is. Het onderzoek geeft inzicht in methodes om koolstofopslag in walnotenbomen te bepalen en toont aan dat de destructieve oogst van enkele bomen nuttig is.

Zhang et al., (2017) mat van walnotenbomen in plantages boomhoogte en DBH in $20 \mathrm{~m} \times 50 \mathrm{~m}$ plots per leeftijdsklasse opgedeeld in $10 \mathrm{~m} \times 10 \mathrm{~m}$ subplots. Hoogte en DBH werden gemeten met hypsometer en rolmaat respectievelijk. Drie bomen van gemiddelde grote werden geoogst om biomassa te bepalen. De grove wortels ( $>2 \mathrm{~mm}$ ) van deze bomen werden in een radius van $1.5 \mathrm{~m}$ en $3.5 \mathrm{~m}$ uitgegraven. Het gemiddelde gewicht van het grove wortel volume werd vermenigvuldigd met het aantal bomen per hectare om de biomassa van ruwe wortels te bepalen. Ook werd biomassa in fijne wortels ( $\leq 2 \mathrm{~mm}$ ) bepaald rond 24 bomen op dieptes tot $100 \mathrm{~cm}$ om het gewicht van fijne wortels per ha te schatten. Biomassa werd gewogen, en gedroogd om houtdichtheid en koolstofgehalte te meten, waarvan de methode verder niet exact is beschreven. Dit onderzoekt toont aan dat koolstofgehalte tussen takken, stammen en op basis van leeftijd verschilt en dat meting van koolstofgehalte voor vervolgonderzoek van belang is.

De biomassa van bomen wordt doorgaans bepaald met niet-destructieve allometrische vergelijkingen. Een veelvoorkomende vorm is $B=a D^{b}$ met biomassa in $B$, diameter $D$ en parameters $a$ en $b$ (Ketterings et al., 2001) Deze vergelijkingen kunnen worden opgesteld door bomen in het geheel te oogsten. Voor walnoten en hazelnoten is dit nog niet gedaan. Bij gebrek aan allometrische 
vergelijkingen en de optie om bomen in het geheel te oogsten is er in dit onderzoek gekozen om een methode gelijkend op die van Cardinael et al., 2017 toe te passen. Zie onderzoeksopzet.

\subsubsection{Bepalingen van koolstofopslag in hazelnotenteelt}

Literatuur over koolstofopslag in biomassa van hazelnoten is onvoldoende beschikbaar om een beeld te geven van de potentiële bijdrage aan klimaatmitigatie. Dit gebrek benadrukt het belang van dit onderdeel van het project en van vervolgonderzoek.

Tabel 4 Koolstofopslag en accumulatiesnelheden in boven- en ondergrondse biomassa walnotenbomen.

Resultaten uit verschillende wetenschappelijke publicaties over C-opslagsnelheden in boven- en ondergrondse biomassa van walnotenbomen. Juglans regia is gewone walnoot, Juglans nigra is zwarte walnoot en Juglans regia $x$ nigra is hybride walnoot.

\begin{tabular}{|c|c|}
\hline Cardinael et al., 2017 (agroforestry) & $\begin{array}{l}\text { Totale boom C-opslag accumulatiesnelheid } \\
\text { (boven- en ondergronds) per ha per jaar }\end{array}$ \\
\hline Site Châteaudun ( 6 j hybride walnoot - 34 bomen/ha) & $0,004 \mathrm{Mg} \mathrm{C}$ \\
\hline Site Melle ( 6 j hybride walnoot - 35 bomen/ha) & $0,02 \mathrm{Mg} \mathrm{C}$ \\
\hline Site Saint-Jean-d'Angély ( 41 j zwarte walnoot - 102 bomen/ha) & $0,62 \mathrm{Mg} \mathrm{C}$ \\
\hline Site Restinclières ( 18 j hybride walnoot - 110 bomen/ha) & $0,77 \mathrm{Mg} \mathrm{C}$ \\
\hline Site Vézénobres ( 18 j hybride walnoot - 100 bomen/ha) & $1,85 \mathrm{Mg} \mathrm{C}$ \\
\hline \multicolumn{2}{|l|}{ Aertsens et al., 2013 (agroforestry) } \\
\hline Frankrijk (30 j zwarte walnoot - 70 bomen/ha) & $0,68 \mathrm{Mg} \mathrm{C}$ \\
\hline Site Restincliéres ( 14 j hybride walnoot - 80 bomen/ha) & $3 \mathrm{Mg} \mathrm{C}$ \\
\hline \multicolumn{2}{|l|}{ Jacobs et al., 2009 (mengteelt plantage) } \\
\hline Wisconsin ( 8 j zwarte walnoot - 3588 bomen/ha) & 1,03 en $4,15 \mathrm{Mg} \mathrm{C}$ \\
\hline Wisconsin (12 j zwarte walnoot - 897 bomen/ha) & $1,77 \mathrm{Mg} \mathrm{C}$ \\
\hline \multirow[t]{2}{*}{ Wisconsin (19 j zwarte walnoot - 960 bomen/ha } & $4,76 \mathrm{Mg} \mathrm{C}$ \\
\hline & $\begin{array}{l}\text { Totale C-opslag in biomassa bomen } \\
\text { (boven- en ondergronds) per ha per jaar }\end{array}$ \\
\hline \multicolumn{2}{|l|}{ Zhang et al., 2017 (monocultuur plantage) } \\
\hline Karst, China (5 j gewone walnoot - 350 tot 450 bomen/ha) & $0,212 \mathrm{Mg} \mathrm{C}(*)$ \\
\hline Karst, China (13 j gewone walnoot - 350 tot 450 bomen/ha) & $0,92 \mathrm{Mg} \mathrm{C}(*)$ \\
\hline
\end{tabular}

*Ervan uitgaande dat ondergrondse biomassa gelijk is rond $20 \%$ bovengrondse, Zhang et al., 2017. 


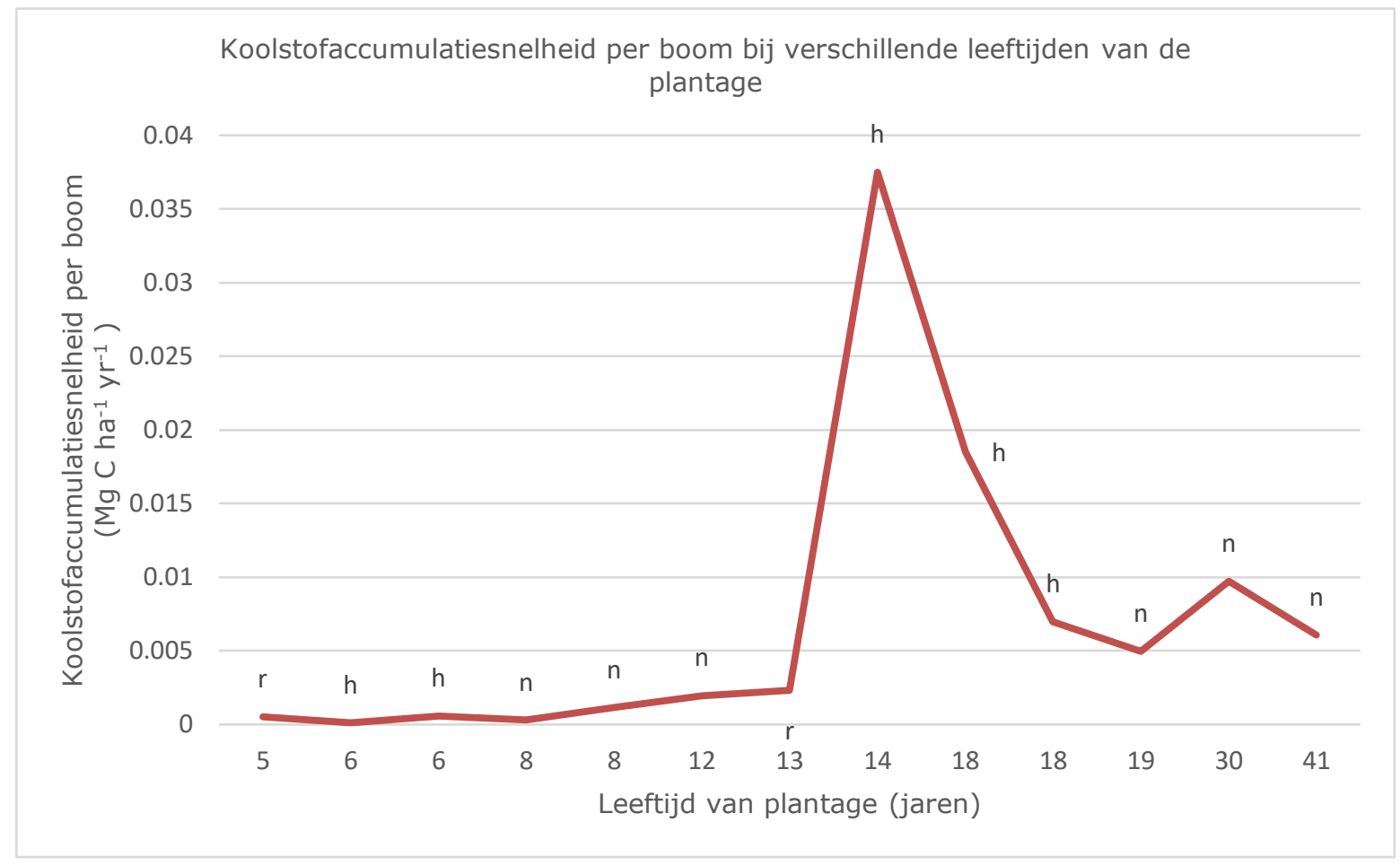

Figuur 5.2 Koolstofaccumulatiesnelheid per boom uitgezet tegen de leeftijd van de plantage.

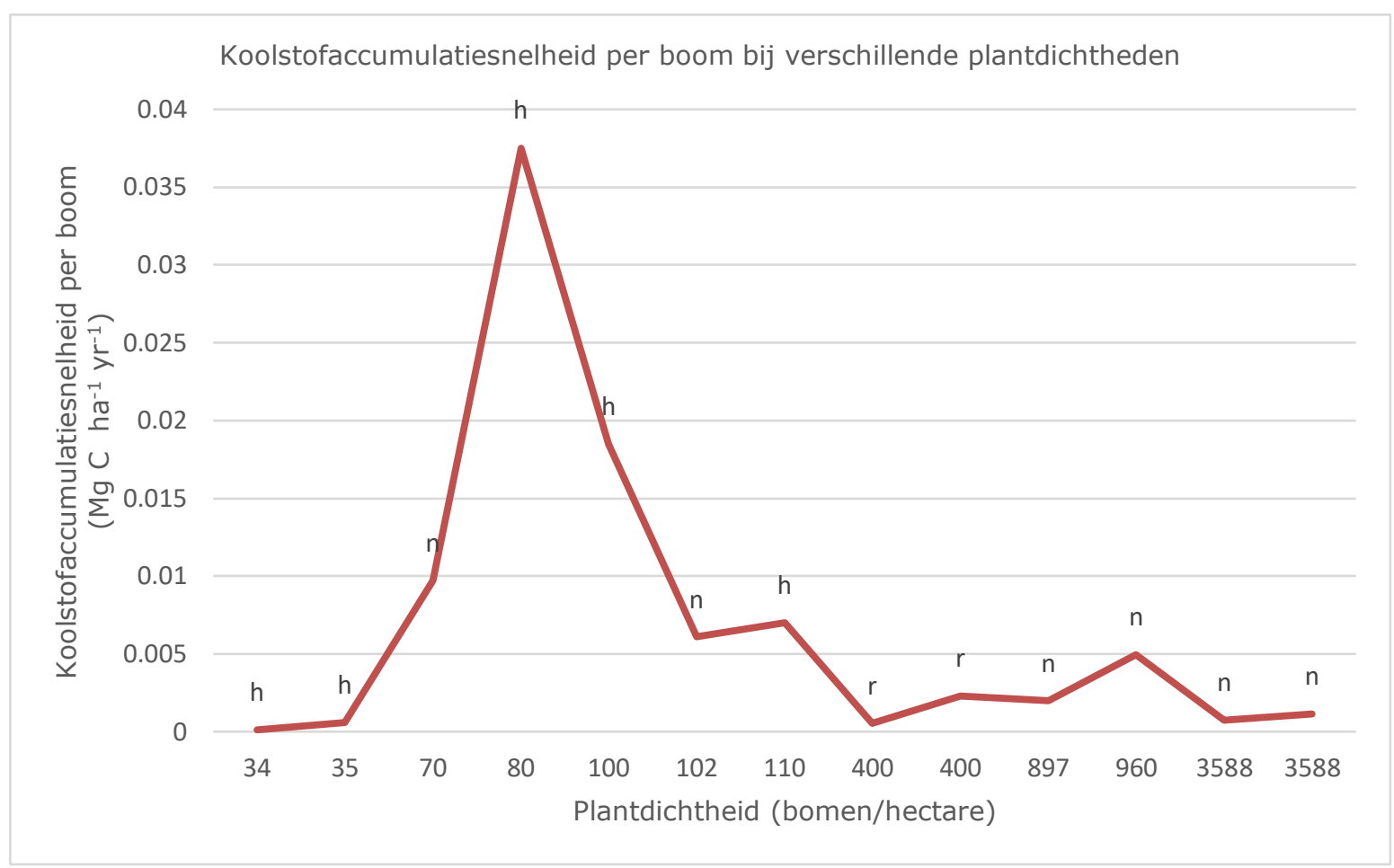

Figuur 5.3 Koolstofaccumulatiesnelheid per boom uitgezet tegen de plantdichtheid.

Figuren 5.2 en 5.3. Koolstofaccumulatiesnelheid per boom uitgezet tegen de plantdichtheid en de leeftijd van de plantage. De ondersteunende data is gehaald uit tabel 4. De h staat voor Juglans regia $\mathrm{x}$ nigra, de $\mathrm{n}$ voor Juglans nigra en de $\mathrm{r}$ voor Juglans regia. 


\subsection{Opslag in bodemorganisch koolstof (SOC)}

De opbouw van soil organic carbon (SOC) verloopt via decompositie van biomassa: snoeimateriaal, afgevallen bladeren, afgestorven grove en fijne wortels en aangevoerd organisch materiaal, zoals mest (Nelissen et al., 2018). Optimale SOC gehalte heeft baat bij hoge biomassaproductie en een hogere toevoer van organisch koolstof (Jandl et al., 2007). SOC draagt significant bij aan de totale globale koolstofopslag (Stockmann et al., 2013), bevordert onder andere de vruchtbaarheid (Lal, 2004), zoals vochtvasthoudend vermogen van de bodem (Rawls et al., 2003) en kan de gewasopbrengst verhogen (Lal, 2004). Voldoende SOC in de bodem is dan ook van groot belang voor de landbouwsector, maar kan alleen in stand worden gehouden door een hoge aanvoer van organisch materiaal (Reubens et al., 2010). Bomen kunnen via blad- tak-, snoeiafval en wortels hier in grote mate aan bijdragen (De Stefano \& Jacobsen, 2018). Anderzijds is voor eenjarige teelten een continue toevoer van organisch materiaal uit andere systemen nodig om het SOC-niveau op peil te houden (Reubens et al., 2010).

Een groot voordeel van bomen is de diepe worteling die opslag van organische koolstof in dieper gelegen, stabielere bodemhorizonnen teweeg kan brengen (Kell, 2012) en de mogelijke opname van nutriënten onbereikbaar voor eenjarige gewaslagen mogelijk maakt (Lorenz \& Lal, 2014). Een nadelig gevolg van deze diepe worteling kan het ontbinden van eerder opgeslagen koolstof zijn (het rhizosfeer priming effect; Fontaine et al., 2007). In Nederland is het onduidelijk of dit een probleem is en in dit onderzoek wordt hier geen rekening mee gehouden. Van belang is dat in vervolgonderzoek verzekerd wordt dat via priming geen grotere verliezen van dieper gelegen koolstof optreedt dan er wordt opgeslagen. Ook kan de wortelgroei beperkt worden door een hoge grondwaterstand of door verdichte lagen.

In 2012 was de totale C-voorraad in de bovenste $30 \mathrm{~cm}$ van Nederlandse bodem geschat op 357 Mton $C$ (Lesschen et al., 2012). Akkerland bevatte in de bovenste $30 \mathrm{~cm}$ de laagste koolstofvoorraad:

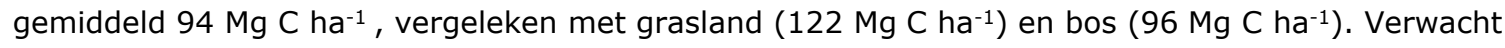
wordt dat notenteelt, net als herbebossing (Lesschen et al., 2012), door de inbreng van houtige gewassen en gras op akkerland het gehalte bodemorganische koolstofopslag kan verhogen (Zhang et al., 2017; Cardinael et al., 2017; De Stefano \& Jacobsen, 2018). Omdat notengaarden vaak een combi betreft van gras met bomen die dieper dan $30 \mathrm{~cm}$ wortelen, wordt bovendien een verhoging van de totale koolstofvastlegging in de bodem verwacht (Lesschen et al., 2012).

Naast klimaatmitigatie is verhoging van het percentage koolstof in de bodem dus van belang voor de landbouwsector. Via notenteelt wordt verwacht dat verhoogde en stabielere bodemorganische koolstofgehaltes kunnen worden gerealiseerd. In tabel 5 is een overzicht gemaakt van resultaten uit de literatuur betreffende koolstof-accumulatiesnelheden en koolstofopslag in de bodem onder walnotenbomen. Wederom is literatuur over bodemorganisch koolstofopslag onder hazelnotenteelt ontoereikend en hier is dus op kennisgebied zeker vooruitgang te boeken.

\subsubsection{Koolstofopslag in bodem onder walnotenbomen}

In tabel 5 wordt een overzicht van resultaten uit de literatuur betreffende koolstofaccumulatiesnelheden en koolstofopslag in bodem gegeven. De walnotengaarden slaan naarmate ze ouder worden meer koolstof op per hectare per jaar en lopen van 0,09 tot 1,01 Mg C $\mathrm{ha}^{-1} \mathrm{j}^{-1}$. Koolstofvoorraden in de bovenste $30 \mathrm{~cm}$ van de bodem kunnen oplopen tot $114,3 \mathrm{Mg} \mathrm{C} \mathrm{ha-1}^{-1}$. De C-accumulatiesnelheid van een 41-jarige agroforestry-systeem met walnotenbomen in Frankrijk besloeg 60,9 Mg C ha-1 in de bovenste $20 \mathrm{~cm}$ (Cardinael et al., 2017), wat lager is dan de gemiddelde koolstofvoorraad in de bovenste $30 \mathrm{~cm}$ van de Nederlands akkerland, grasland en bos. De eenjarige teelt die Cardinael et al. (2017) als controle gebruikte sloeg echter slechts $42,1 \mathrm{Mg} \mathrm{C} \mathrm{ha-1}$ op. Dus het verschil kan liggen aan de plaatselijke condities. De verschillen in accumulatiesnelheid zijn afhankelijk van de methodiek van de studie en van de specifieke condities die heersten in de boomgaarden. Hieronder wordt hier op deze verschillen ingegaan en worden er getracht lessen uit de benaderingswijzen te trekken voor dit onderzoek en vervolgonderzoek.

Cardinael et al., 2017 nam bodemmonsters op vaste posities tussen de rijen bomen en tussen de bomen in de rij op basis van een kwart van de Voronoi polygoon. De Voronoi polygoon is de ruimte die wordt gedefinieerd door de halve afstanden tussen de bemonsterde boom en zijn buren. Dit patroon wordt doorgaans gebruikt om biomassa in de wortels te schatten. Naar verhouding werd dit per boomgaard aangepast zodat ze vergelijkbaar bleven. Aanliggende eenjarige teelten werden op 
dezelfde wijze bemonsterd om te fungeren als referentiepercelen. Ringmonsters voor de bodemdichtheid werden op elke $10 \mathrm{~cm}$ van het bodemoppervlak genomen. Totale voorraad aan bodemorganisch koolstof is vervolgens berekend op basis van equivalente bodemmassa om vergelijking tussen en binnen alle locaties mogelijk te maken. De data in tabel 5 betreft de gemiddelde accumulatiesnelheid in de bovenste $30 \mathrm{~cm}$ van de bodem, berekend door de koolstofvoorraad in de referentiepercelen van die in de agroforestry-systemen af te trekken en te delen door het aantal jaren sinds aanplant.

Zhang et al., 2017 nam tien samengestelde monsters op dieptes van 0-10, 10-20, 20-30, 30-50 en $50-100 \mathrm{~cm}$ in het midden van de subplots van elke plot. Drie grondmonsters werden per subplot genomen en tot één samengesteld monster gemixt. Om gronddichtheid te meten op verschillende dieptes werden met ringen zes monsters per diepte gestoken. De koolstofvoorraad in tabel 5 is de gemiddelde hoeveelheid koolstof in bovenste $1 \mathrm{~m}$ van de bodem per hectare. Er was geen referentieperceel gekozen.

Bij gebrek aan tijd en hulpmiddelen is gekozen voor een versimpelde versie van de methode toegepast door Cardinael et al., 2017. Zie onderzoeksopzet.

Tabel 5 Koolstofopslag en accumulatiesnelheden in bodem onder walnoten.

\begin{tabular}{|c|c|}
\hline Cardinael et al., 2017 (agroforestry) & $\begin{array}{c}\text { SOC-opslag }(0-30 \mathrm{~cm}) \text { accumulatiesnelheid } \\
\text { in ha per jaar }\end{array}$ \\
\hline Site Châteaudun ( 6 j oude hybride walnoot - 34 bomen/ha) & $0,29 \mathrm{Mg} \mathrm{C}$ \\
\hline Site Melle ( $6 \mathrm{j}$ oude hybride walnoot - 35 bomen/ha) & $0,09 \mathrm{Mg} \mathrm{C}$ \\
\hline Site Saint-Jean-d'Angély ( 41 j oude zwarte walnoot - 102 bomen/ha) & $0,46 \mathrm{Mg} \mathrm{C}(0-20 \mathrm{~cm}$ ipv $0-30 \mathrm{~cm})$ \\
\hline Site Restinclières ( $18 \mathrm{j}$ oude hybride walnoot -110 bomen/ha) & $0,25 \mathrm{Mg} \mathrm{C}$ \\
\hline Site Vézénobres ( 18 j oude hybride walnoot - 100 bomen/ha) & $0,11 \mathrm{Mg} \mathrm{C}$ \\
\hline \multicolumn{2}{|l|}{ Aertsens et al., 2013 (agroforestry) } \\
\hline \multicolumn{2}{|l|}{ Frankrijk (30 j oude zwarte walnoot - 70 bomen/ha) } \\
\hline \multirow[t]{2}{*}{ Site Restincliéres ( 14 j oude hybride walnoot - 80 bomen/ha) } & $0,1-0,5 \mathrm{Mg} \mathrm{C}$ \\
\hline & Total SOC -opslag $(0-100 \mathrm{~cm})$ per ha \\
\hline \multicolumn{2}{|l|}{ Zhang et al., 2017 (monocultuur plantage) } \\
\hline Karst, China (13 j oude walnoot - 350 tot 450 bomen/ha) & $65,34 \mathrm{Mg} \mathrm{C}$ \\
\hline
\end{tabular}

Resultaten uit verschillende wetenschappelijke publicaties betreffende C-opslagsnelheden en voorraden in de bodem onder walnotenplantages vergeleken met eenjarige teelt (SOC = bodemorganische koolstof). Juglans regia is gewone walnoot, Juglans nigra is zwarte walnoot en Juglans regia $x$ nigra is hybride walnoot.

\subsection{Modellering van koolstofopslag in boven- en ondergrondse biomassa en bodem}

Modelvorming of simulatie is een andere manier, naast werkelijke berekeningen zoals beschreven in voorgaande paragrafen, om de koolstofopslag in boven- en ondergrondse biomassa en bodem, en daarmee dus de potentie van notenteelt in Nederland aan klimaatmitigatie, te bepalen. Bij het modelleren worden allerlei data uit verschillende bronnen gebruikt. Het modelleren zelf valt buiten de scope van dit deelonderzoek.

In het gros van literatuur worden twee modellen aangehaald voor modellering van koolstofopslag in houtachtige gewassen: CO2Fix en Yield-SAFE (Schelhaas, 2004; van der Werf et al., 2007). CO2Fix is van origine ontwikkeld voor modellering van koolstofopslag in bossen maar wordt ook gebruikt voor agroforestry-systemen. Yield-SAFE wordt gebruikt voor agroforestry-systemen. 


\subsubsection{CO2Fix}

Voor het modelleren van totale koolstofopslag via CO2Fix dienen verschillende parameters te worden vastgesteld. Deze zijn terug te vinden in de handleiding van Schelhaas(2004). Een lijst van de in dit rapport nog niet bepaalde parameters die nodig zijn om een accuraat model te maken met CO2Fix volgen in Tabel 6 en Tabel 7.

Tabel 6 Parameters nodig om koolstofopslag in biomassa via CO2Fix te modelleren.

\begin{tabular}{|c|c|}
\hline Biomassaparameters voor C02Fix modellering & Hoe mogelijk te verkrijgen? \\
\hline Groei van stamvolume ha-1 & $\begin{array}{l}\text { Voor walnoot: groeitabel modelgewas (Prunus avium) of eigen } \\
\text { metingen aan walnotengaarden met uiteenlopende leeftijden } \\
\text { gecombineerd met wat te vinden is in literatuur } \\
\text { Voor hazelnoot: best om te baseren op eigen metingen aan } \\
\text { hazelnootgaarden met uiteenlopende leeftijd }\end{array}$ \\
\hline $\begin{array}{l}\text { Groei van bladeren, takken en wortelen als fracties van } \\
\text { stamvolume }\end{array}$ & $\begin{array}{l}\text { Via de destructieve oogst van enkele bomen, of deze gegevens } \\
\text { moeten op basis van literatuur worden geschat (Schelhaas et } \\
\text { al., 2004). }\end{array}$ \\
\hline Koolstofgehalte droge biomassa & $\begin{array}{l}\text { Oogst van biomassa, kan bepaald worden na uitdunning of } \\
\text { snoei of worden gebaseerd op literatuur }\end{array}$ \\
\hline Houtdichtheid & $\begin{array}{l}\text { Oogst van biomassa, kan bepaald worden na uitdunning of } \\
\text { snoei of worden gebaseerd op literatuur }\end{array}$ \\
\hline Boomsterfte door natuurlijk oorzaak of management & Via notenteler, literatuur of opbrengsttabellen \\
\hline $\begin{array}{l}\text { Snoei en uitdunning op basis van a. de leeftijd wanneer de } \\
\text { interventie plaatsvindt, de intensiteit van de interventie } \\
\text { (hoeveel biomassa verwijderd) en de toewijzing van de } \\
\text { verwijderde biomassa }\end{array}$ & Via notenteler \\
\hline
\end{tabular}

In CO2Fix wordt het model van Yasso (Liski et al., in prep., http://www.efi.fi/projects/yasso/) gebruikt. Hierin worden decompositie en bodemorganische koolstopopslag-dynamica op goed doorlatende gronden gesimuleerd. Bodemorganische koolstofopslag wordt in de totale bodem gepresenteerd, dus niet per laag.

Tabel 7 Parameters nodig om koolstofopslag in bodem via CO2Fix te modelleren.

\begin{tabular}{|c|c|}
\hline Bodemparameters voor CO2Fix modellering & Hoe mogelijk te verkrijgen? \\
\hline Soorten en hoeveelheden boomafval & Bepaald in de biomassa-module \\
\hline Chemische kwaliteit boomafval & $\begin{array}{l}\text { Zelf bepalen of de beschikbare standaard parameters voor } \\
\text { loofbomen te gebruiken }\end{array}$ \\
\hline Temperatuurgevoeligheid van boomafval & $\begin{array}{l}\text { Zelf bepalen of de beschikbare standaard parameters voor } \\
\text { loofbomen te gebruiken }\end{array}$ \\
\hline Initiële decompositie & $\begin{array}{l}\text { Zelf bepalen of de beschikbare standaard parameters voor } \\
\text { loofbomen te gebruiken }\end{array}$ \\
\hline $\begin{array}{l}\text { Effectieve temperatuursom (graaddagen boven nul) gedure } \\
\text { het jaar }\left({ }^{\circ} \mathrm{C} d\right) \text {, periode van het groeiseizoen, neerslag in } \\
\text { groeiseizoen }(\mathrm{mm}) \text {, en potentiële evapotranspiratie in het } \\
\text { groeiseizoen }(\mathrm{PET}, \mathrm{mm}) \text {, }\end{array}$ & Bronnen op internet of CliPick (Palma et al., 2017a) \\
\hline
\end{tabular}

\subsubsection{Yield-SAFE}

Yield-SAFE is een model ontwikkeld om bovengrondse biomassa en koolstofopslag in agroforestrysystemen te modelleren (van der Werf et al. 2007). Voor de modellering van bodemorganische koolstof is 'The Rothamsted Carbon Model (RothC) (Coleman and Jenkinson 2014) in Yield-SAFE verwerkt door Palma et al., 2018. Omdat Yield-SAFE en RothC meer parameters behoeven dan CO2Fix, wordt er verwezen naar van der Werf et al., 2007 en Palma et al., 2017b. Een simpelere toepassing is echter ook beschikbaar in de vorm van een website, zie http://www.isa.ulisboa.pt/proj/ecoyieldsafe/\#/dashboard. 
Beperkende factor in deze applicatie is dat er een beperkte hoeveelheid boomsoorten beschikbaar zijn voor de simulatie (o.a. Prunus avium) en geen nieuwe toe te voegen zijn. Voor de standaard modellering kan de boomsoort aangepast worden via een set parameters. Interessant is bovendien dat in Palma et al., 2017b zwarte walnoot (Juglans nigra) wordt genoemd, waar al eerder voor een agroforestry-systeem in Spanje met Yield-SAFE gewerkt is en op basis van de literatuur parameters zijn bepaald. 


\section{Referentiepercelen}

\subsection{Onderzoeksopzet}

De doelstelling van dit deelonderzoek is het vastleggen van de uitgangssituatie om langjarige effecten te kunnen meten van notengaarden op de levering van de agro-ecosysteemdienst koolstofopslag en die te vergelijken met eenjarige teeltsystemen. In de herfst/winter van 2018 zijn twee hazelnoten- en twee walnotentelers en aangelegen monoculturen als referentiepercelen geselecteerd voor nader onderzoek van koolstofopslag. Met behulp van diepte-interviews is het bedrijfs- en teeltsysteem en management nauwkeurig beschreven, van datum van aanplant tot huidige situatie. Op deze vier locaties is dan ook de uitgangssituatie vastgelegd van de agro-ecosysteemdienst koolstofopslag in boven- en ondergrondse biomassa en in bodemorganische stof.

\subsection{Omschrijving bedrijfssystemen notentelers}

\subsubsection{Walnotengaard bij Luttelgeest}

Deze biologische walnoten- en hazelnotengaard ligt in provincie Flevoland, nabij Luttelgeest. Aan het perceel grenst akker- en weidebouw. De afmeting van de notengaard is $200 \times 80 \mathrm{~m}$ (1,6 ha). Aanplant vond plaats in 1996 en 1997 met een plantafstand van 7,5 m. Tussen de walnotenbomen stond hazelnoot en stikstof fixerende duindoorn op 3,75 m, nu beide grotendeels gerooid. Na deze uitdunning is de afstand tussen de walnotenbomen dus 7,5 m. De oorspronkelijke rassenkeuze in soort (aantal) betrof Dionym (86), Amphyon (37), Cyril, (14) Hansen (5), Broadview (4), Melange (45) en W16 (3). Deze zijn nog steeds aanwezig. Bestuivers bestonden uit 26 stuks, allen geleverd door Kwanten, van W17, W8, nr 26, pseudo W16 en nr. 22. De gekozen snoeivorm is die van de vaasvorm.

De grondsoort is Blokzijlerzand. Deze grondsoort bestaat uit fijn zand, is erg kalkrijk en bevat een hoog calcium- en een laag magnesiumgehalte en een hoge $\mathrm{pH}$. Bijgevolg kan de bodemstructuur van mindere kwaliteit zijn en de dichtheid hoog. Periodiek kan het zuurstofgehalte laag zijn en de beworteling beperkt door de hoge dichtheid (Heineke, 2010). Het organische stof-gehalte (SOM), de exacte $\mathrm{pH}$, het waterpeil in de winter en zomer, zijn onbekend. Er is nooit eerder een bodembemonstering uitgevoerd. Er vindt geen bemesting plaats op het perceel. Het gras wordt regelmatig gemaaid. Maaisel blijft liggen en wordt verteerd. Snoei van lage takken vindt plaats in juni als boom vol in blad is. De gesnoeide takken worden afgevoerd naar houtwallen aan de zijden van het perceel. Noten worden ongekraakt verkocht dus de omhulsels worden afgevoerd. Voor ziektes en plagen worden er geen maatregelen getroffen.

Het referentieperceel grenst aan noordzijde van het notenperceel, richting de oude dijk van het IJsselmeer welke nog zichtbaar is in de verte. Sinds 4 jaar wordt er een eenjarige teelt gehandhaafd een rotatie van gras, tulpen, lelies, aardappels, gras en uien. Er zijn geen resultaten van bodemanalyses beschikbaar. Jaarlijks wordt met $3550 \mathrm{~m}^{3}$ vloeibare rundvee mest bemest. Er wordt tot een diepte van $25 \mathrm{~cm}$ geploegd.

\subsubsection{Walnotengaard in Herveld}

Deze walnotengaard bevindt zich in Gelderland, in Herveld. Aan het bemonsterde perceel grenst grasland en akkerbouw. De afmeting van het perceel is $200 \times 30 \mathrm{~m}$ (0,6 ha). Aanplant vond plaats in december 2016 (465 bomen ha-1). De plantafstand bij aanplant was $4 * 4 \mathrm{~m}$ ( 625 bomen ha-1). Dunning heeft nog niet plaatsgevonden. De rassenkeuze is gevallen op Bella Maria (hoofdras), Coenen (hoofdras) en Lange van Lod, met Buccaneer als bestuiver. De snoeivorm is met harttak. Voor de noten was het perceel in gebruik als perenboomgaard. 
De walnoten groeien op rivierklei. Het SOM-gehalte was 5,3\% en pH was 6,6 in 2018. Het waterpeil in de winter was $110 \mathrm{~cm}$ en in de zomer $140 \mathrm{~cm}$. Er wordt om het jaar in december met circa 46.500 I paardenmest met veel vlas en wat stro toegediend. Onderhoud van de ondergroei in de boomstrook of zwartstrook wordt gedaan door te schoffelen dan wel te plukken. Tussen de bomenrijen wordt gemaaid. Maaisels worden gemulcht op de rijpaden. Tegen bacteriebrand of de bladvlekkenziekte wordt rond de bloei gespoten met Serenade. Zo nodig wordt tegen diverse rupsen, kevers en walnootviltmijt gespoten met Xen Tari. In principe wordt kort na het uitlopen van de bomen gesnoeid, zo nodig vlak na de oogst. Snoeisel wordt gemulcht.

Het referentieperceel bevond zich enkele honderd meters verderop. Sinds 1976 werden hier eenjarige gewassen geteeld. Voor 1976 vond er fruitteelt plaats. De actuele rotatie betreft tarwe $1 / 2$, aardappelen $1 / 4$, suikerbieten $1 / 4$ en zaaiuien $1 / 8$. Het SOM-gehalte was $3,2 \%$ en $\mathrm{pH} 7,2$ bij de laatste bemonstering (jaartal onbekend). Er wordt bekalkt met Betacalflow. Bemesting met $25 \mathrm{~m}^{3}$ varkensdrijfmest per ha vindt plaats na de teelt van wintertarwe, soms in combinatie met een groenbemester. Gemiddeld wordt er een effectieve organische stof (EOS) aanvoer van $4500 \mathrm{~kg} \mathrm{ha}^{-1}$ per jaar bereikt met de afvoer van graan als hakvrucht en Champost/groenbemester. Tot op een diepte van rond de $26-28 \mathrm{~cm}$ wordt er geploegd.

\subsubsection{Hazelnotengaard in Breedenbroek}

Deze biologische hazelnotengaard ligt in Breedenbroek, Gelderland. Het bemonsterde perceel grenst aan akkerbouw. Voor aanplant was het een akkerbouwperceel met maisteelt en om de 4 jaar aardappelen. De afmeting van het perceel is $186 \times 120 \mathrm{~m}$ (2,23 ha). Aanplant vond plaats in '92, '93 en ' 94 op een plantafstand in de rij van $2,2 \mathrm{~m}$ en tussen rijen van $4.4 \mathrm{~m}$. Bij tijd van bemonstering was er door uitdunning een afstand van $4,4 \mathrm{~m}$ in de rij en een afstand van $8,8 \mathrm{~m}$ tussen de rijen ontstaan. De oorspronkelijke rassenkeuze betrof Gunslebert en Lang Tidlig Zeller (LTZ). 1/4 van de bomen zijn bestuivers, bestaande uit Cosford, Impératrice Eugénie en Lange Spaanse. Er wordt een vaasvorm op stam onderhouden.

De hazelnoten groeien op zavelgrond, $13 \%$ afslibbaar. Het SOM-gehalte was 3,7\%, de pH was 4,9, beide bepaald in 1997. De grondwaterstand is in de winter $60-90 \mathrm{~cm}$ en in de zomer $120-150 \mathrm{~cm}$. Er wordt jaarlijks midden mei ongeveer $20 \mathrm{~m}^{3}$ runderdrijfmest uitgereden. De zwartstrook wordt goed onderhouden door in het voorjaar te schoffelen en de $2^{e}$ helft van het groeiseizoen te branden. De grasbaan tussen de bomenrijen wordt gemaaid. Het maaisel of de onkruiden worden er met er met de schoffel ingewerkt of na branden afgevoerd naar de composthoop. In de winter wordt er gesnoeid. Rond de $300 \mathrm{~kg}$ snoeihout per ha per jaar en $300 \mathrm{~kg}$ haardhout per ha per jaar (droog) wordt er bij het snoeien geoogst. $2 / 3$ hiervan wordt afgevoerd en $1 / 3$ gecomposteerd. De schaaldelen van gepelde noten worden op de composthoop gegooid. Voor ziektes worden geen maatregelen getroffen. Maatregelen tegen de hazelnootboorder beperken zich tot het vangen van meikevers met een lichtval. De teelt op het referentieperceel was mais. Er is verder geen informatie over het referentieperceel bekend.

\subsubsection{Hazelnotengaard in Lelystad}

Deze hazelnotengaard ligt in Lelystad, provincie Flevoland. Aan het bemonsterde perceel grenst grasland, een tuin op een erf en braakliggende grond. Tot en met 1996 was het perceel in gebruik voor biologische akkerbouw. Het perceel is 1,0 ha groot, eerst beplant in 1997 met een gras-klaver mengsel en vervolgens later in het jaar met de hazelnotenbomen. Plantafstand bij aanplant was in de rij 2,75 m en tussen de rijen $4 \mathrm{~m}$. Uitdunning heeft niet plaatsgevonden. De rassenkeuze bestond uit Gunslebert, Lang tidlig zeller, Gustav zeller, Emoa-1, Corabel, Pauetet en Gonda di Tifoni met 90 op 600 de bestuiver Corabel. De snoeivorm is eveneens een vaasvorm.

De grondsoort is zavel, $19 \%$ afslibbaar. Het SOM-gehalte is onbekend en $\mathrm{pH}$ is waarschijnlijk $\sim 7$ vanwege de aanwezigheid van kalk. Het waterpeil in de winter is hoog, zo'n $50-100 \mathrm{~cm}$ onder het maaiveld. In de zomer varieert het waterpeil. In 19 jaar is er in totaal tweemaal 40 ton runderdrijfmest, 8 ton pluimveemest en $25 \mathrm{~m}^{3}$ groencompost toegediend. De aanwezige zwartstrook wordt onderhouden door te frezen en de strook tussen bomenrijen wordt 2-3 keer per jaar gemaaid. Maaisel blijft onder de bomen liggen. Bomen gestorven door te hoge grondwaterstand of droogte worden gerooid. Ook tegen plagen als de Rondknopmijt wordt er gerooid. Tegen andere plagen 
worden geen maatregelen getroffen. Er wordt rond de $20 \mathrm{~kg}$ aan boommateriaal per jaar gesnoeid vanaf november tot en met half maart. Het snoeisel wordt versnipperd en onder de bomen verspreid. Het referentieperceel grenst aan de oostzijde van het notenperceel. SOM-gehalte en $\mathrm{pH}$ zijn eveneens onbekend en het waterpeil in de winter is gelijksoortig. Rond 19 jaar geleden werd er akkerbouw op bedreven. Daarna heeft er 10-15 jaar luzerne op gegroeid waarna het braak lag. Van bemesting, rotatie of ploegen is geen sprake. Op het moment is het een bouwterrein voor een manege.

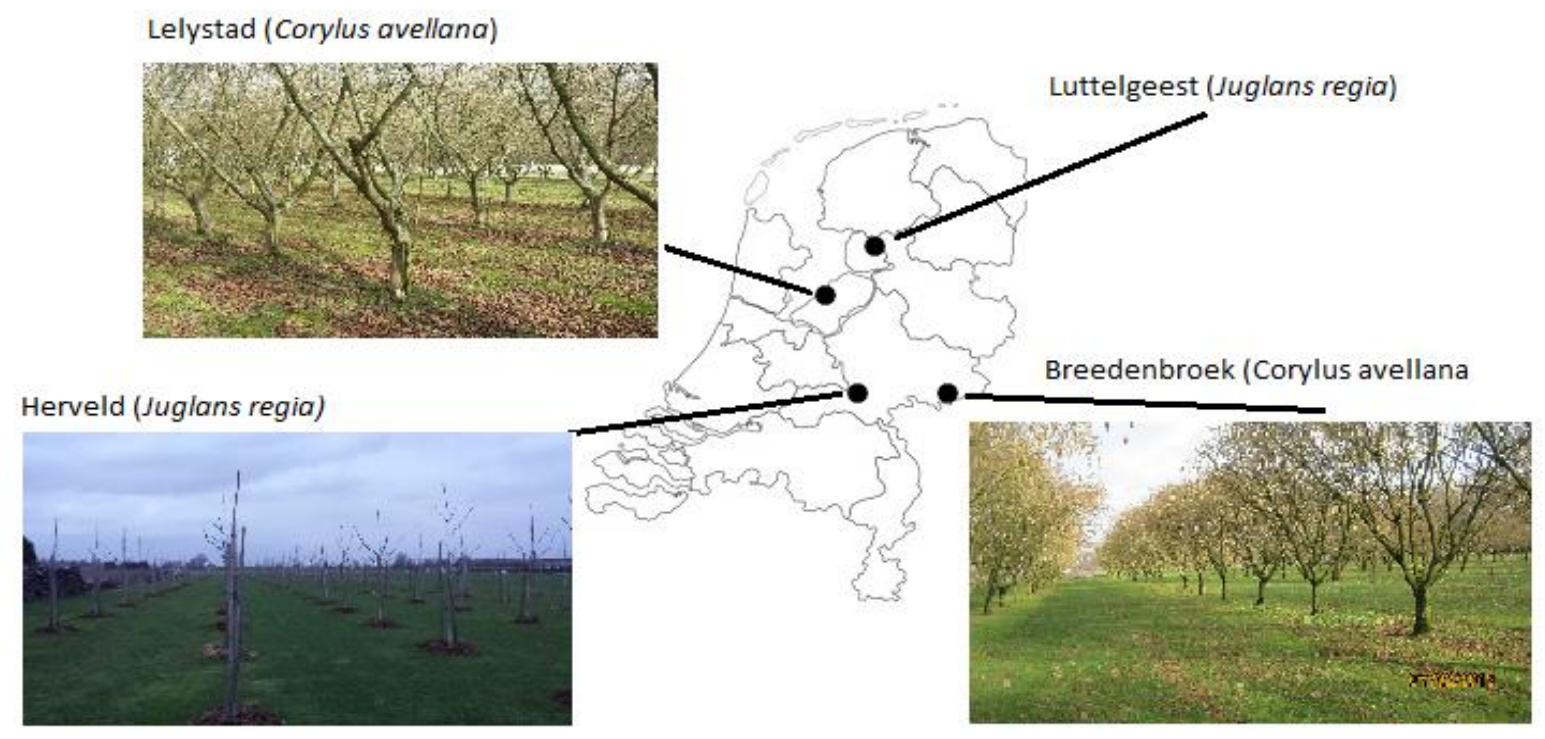

Figuur 6.1 Locatie van de vier notengaarden en aangelegen referentiepercelen in Nederland.

Tabel $8 \quad$ Locaties en ontwerp van bemonsterde notengaarden.

\begin{tabular}{|c|c|c|c|c|}
\hline Plaats & Luttelgeest & Herveld & Breedenbroek & Lelystad \\
\hline Aangeplant sinds & 1996 en 1997 & 2016 & 1992, 1993 en 1994 & 1997 \\
\hline Boomsoort & Juglans regia & Juglans regia & Corylus avellana & Corylus avellana \\
\hline Bomen per ha & 124 & 465 & 258 & 600 \\
\hline Huidige plantafstand in rijen $(\mathrm{m})$ & $7,5 \mathrm{~m}$ & $4 \mathrm{~m}$ & $4,4 \mathrm{~m}$ & $2,75 \mathrm{~m}$ \\
\hline Huidige plantafstand tussen rijen (m) & $7,5 \mathrm{~m}$ & $4 \mathrm{~m}$ & $8,8 \mathrm{~m}$ & $4 \mathrm{~m}$ \\
\hline
\end{tabular}

Tabel 9 Karakteristieken ligging notengaarden.

\begin{tabular}{|c|c|c|c|c|}
\hline Plaats & Luttelgeest & Herveld & Breedenbroek & Lelystad \\
\hline Jaarlijks gemiddelde temperatuur $\left({ }^{\circ} \mathrm{C}\right)$ & $10,13^{\circ} \mathrm{C}$ & $10,13^{\circ} \mathrm{C}$ & $10,13^{\circ} \mathrm{C}$ & $10,13^{\circ} \mathrm{C}$ \\
\hline \multicolumn{2}{|c|}{$\begin{array}{l}\text { Jaarlijks gemiddelde neerslag sinds datum van aanplant } 811,5 \mathrm{~mm} \\
(\mathrm{~mm})\end{array}$} & $625,7 \mathrm{~mm}$ & $834,3 \mathrm{~mm}$ & $841,3 \mathrm{~mm}$ \\
\hline Grondsoort & Blokzijlerzand & Rivierklei & \multicolumn{2}{|c|}{$\begin{array}{r}\text { Zavel, } 13 \% \text { afslibbaarZavel, } 19 \% \\
\text { afslibbaar }\end{array}$} \\
\hline $\mathrm{pH}$ & $\sim 7,5$ & $\sim 6,6$ & $\sim 4,9$ & $\sim 7$ \\
\hline SOM-aanvoer $\left(\mathrm{kg} \mathrm{ha}^{-1} \mathrm{j}^{-1}\right)$ & Geen & $6400 \mathrm{~kg}$ ha & $636,77 \mathrm{~kg} \mathrm{ha}$ & Niet regelmatig \\
\hline REF landgebruik & Eenjarige teelt & Eenjarige teelt & Eenjarige teelt & $\begin{array}{l}\text { Braakliggende } \\
\text { grond }\end{array}$ \\
\hline REF SOM-aanvoer (kg ha-1 $\left.\mathrm{j}^{-1}\right)$ & $3550 \mathrm{~kg} \mathrm{ha}^{-1}$ & $4500 \mathrm{~kg} \mathrm{ha}^{-1}$ & Geen data & Geen \\
\hline
\end{tabular}




\subsection{Bodembemonstering voor organische koolstofmetingen en bepaling van de dichtheid}

In de notengaard werden twee rijen bomen met de meest representatieve cultivar van de boomgaard gekozen. Op drie afstanden per boom op dieptes van 0-30 cm en 30-60 cm werden mengmonsters gestoken met gutsboren. $\mathrm{Er}$ is 10 keer gestoken om een mengmonster te verzamelen van ongeveer 1 $\mathrm{kg}$ grond, waarbij er twee bomen in de rij werden overgeslagen per herhaling. In totaal zijn na menging twaalf monsters per notengaard verzameld. In de referentiepercelen zijn er eveneens tien herhalingen gestoken voor de $0-30 \mathrm{~cm}$ en de $0-60 \mathrm{~cm}$ om tot twee mengmonsters te komen van $1 \mathrm{~kg}$ voor beide dieptes. Het was nodig de grondbemonstering aan te passen op de specifieke inrichting van de notengaarden. Hierop volgend zal dit per notengaard besproken worden.

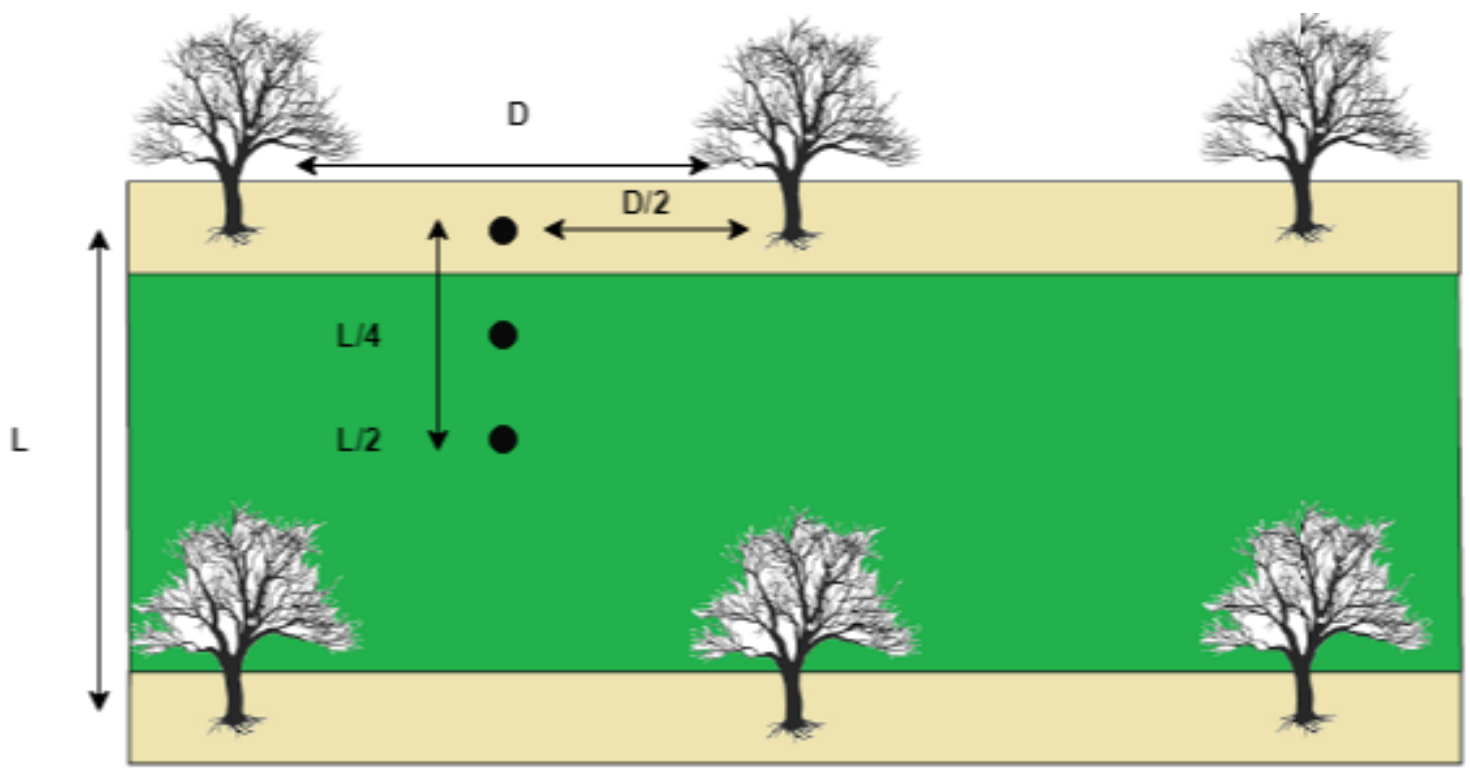

Figuur 6.2 Grondbemonstering voor notengaarden in Herveld, Breedenbroek en Lelystad op drie afstanden van de boomstrook. Uitgevoerde grondbemonstering in Herveld, Breedenbroek en Lelystad waarbij $D$ de afstand is tussen bomen in de rij en $L$ de afstand is tussen rijen. De zwarte stip in de rij wordt de 1e monsterafstand genoemd, die op L/4, de 2e en die op L/2 de $3 e$.

\subsubsection{Grondbemonstering Breedenbroek, Lelystad en Herveld}

Omdat deze notengaarden uitsluitend uit hazelnoten of walnoten bestonden was het bemonsteringsprotocol onderling gelijksoortig. Er is bemonsterd midden tussen twee bomen in dezelfde rij, en vervolgens van deze afstand naar het midden tussen twee rijen bomen toegewerkt om eveneens te komen tot drie monsters per boom. Op de hazelnotengaard in Breedenbroek betrof dit een afstand van 2,2 $\mathrm{m}$ in rij 4 en 5, met vervolgens een afstand van ongeveer $1 \mathrm{~m}$ van de eerste steek richting de andere rij, beide vallend in de zwartstrook. Het derde monster werd gestoken in het midden tussen de rijen op een afstand van 4,4 $\mathrm{m}$ van de 1e steek. Volgens dezelfde methodiek is er in Lelystad gestoken op 1,375 m tussen de bomen in de vierde rij, op ongeveer 1,50 richting de andere rij bomen, en in het midden tussen de rijen bomen op 2,125 m afstand van het eerste monster. In de zesde rij is dit gespiegeld. In Herveld is er op afstanden van $2 \mathrm{~m}$ tussen de bomen gestoken, op een loodrechte afstand van $1 \mathrm{~m}$ van dit eerste monster richting de andere bomenrij en vervolgens op een afstand in het midden tussen de rijen van $2 \mathrm{~m}$. Op ongeveer de hoogte van de tweede monstername is op twee plaatsen in twee rijen, zoveel mogelijk naar het midden van de notengaard gelegen, een kuil gegraven rond $60 \mathrm{~cm}$ diep. Hierin zijn met hamer ringen horizontaal in de grond geslagen, ervoor zorgend dat de middellijn van de ring op 15 en $45 \mathrm{~cm}$ diepte lag. Per kuil zijn er twee monster op 15 $\mathrm{cm}$ en twee monsters op $45 \mathrm{~cm}$ diepte genomen, in totaal vier monsters per diepte per notengaard. Deze ringmonsters zijn gebruikt om de dichtheid van de grond te meten. 


\subsubsection{Bodembemonstering Luttelgeest}

Aangezien deze notengaard walnoten, hazelnoten en duindoorn bevatte was de keuze van de grondbemonstering afwijkend van die toegepast op de andere locaties. In een groot deel van de rijen bomen stonden de gekapte boomstronken van hazelnootbomen op 3,75 m tussen de walnotenbomen. Daarnaast werden de bemonsterde rijen op 3,75 $\mathrm{m}$ afstand geflankeerd door rijen duindoorn. Er is geprobeerd afstand te houden van hazelnoot en duindoorn om zo de effecten van de walnotenbomen op koolstofopslag in de bodem te meten. Toch is het waarschijnlijk dat het bodemorganisch koolstofgehalte beïnvloed wordt door de wortels en bladafval van de hazelnootbomen en de duindoornstruiken. Mogelijk hebben de stikstofbindende duindoornstruiken ook het stikstofgehalte in de bodem beïnvloed, wat een effect kan hebben op bodemorganische koolstof. In rij drie zijn drie grondmonsters gestoken op afstanden van ongeveer $1,875 \mathrm{~m}$ vanaf de walnotenboom, in lijn met de rij bomen, op een afstand van ongeveer 2,25 m op een hoek van $30^{\circ}$ en op een afstand van ongeveer $3 \mathrm{~m}$ op een hoek van $45^{\circ}$. In rij zes is dit protocol gespiegeld en herhaald. De ringmonsters zijn vervolgens op identieke wijze als bij de andere notengaarden uit $60 \mathrm{~cm}$ diepe kuilen gestoken.

\subsubsection{Verwerking van bodemmonsters door Eurofins}

Alle grondmonsters zijn vervolgens opgestuurd naar het laboratorium Eurofins voor analyse van organische stof (OS; elementair), klei, pH-CaCL2, stikstof-totaal en koolstof-totaal en koolzure kalk. In Bijlage 6 worden resultaten van de bodemmonsters van de vier referentiepercelen gepresenteerd.

\subsubsection{Meting volumieke massa}

De in de kuilen gestoken ringmonsters zijn in een oven gedroogd voor 48 uur op $105^{\circ} \mathrm{C}$. Vervolgens zijn ze direct na het verwijderen uit de oven gewogen op een weegschaal die tot twee decimalen na de komma aangaf. Dit gewicht is genoteerd en door hier het al bekende gewicht van de ringen af te trekken is het soortelijk gewicht van de grond vastgesteld in een eveneens bekend volume $\left(\mathrm{g} \mathrm{cm}^{-3}\right)$.

\subsection{Berekening bodemorganisch koolstof per hectare}

$\mathrm{Er}$ is geen berekening van de bodemorganische koolstop per hectare uitgevoerd, omdat er per abuis geen data over bodemorganische koolstof terug is gekomen van Eurofins. Het plan was hiervoor de notengaard op te delen in drie stroken. De stroken waren even wijd aan weerszijden van de drie meetpunten en waren samen even breed als de afstand tussen twee boomstroken. Met de volumieke massa van de dieptes van $15 \mathrm{~cm}$ of $45 \mathrm{~cm}$ en de lengte van de stroken kon de inhoud van de 0-30 cm en de 30-60 cm bodemlaag worden berekend per hectare. De aanname werd gemaakt dat de volumieke dichtheid tweemaal genomen op uitsluitend de tweede afstand representatief was voor de gehele boomgaard. Vermenigvuldiging van de uitkomst met het gemiddelde percentage aan bodemorganisch koolstof in de drie meetpunten kon een schatting geven van het totale koolstofopslag in de bodem per hectare.

\subsection{Hoogte van bomen en diameter op borsthoogte $(\mathrm{DBH})$}

Van 12 bomen per notengaard, is de diameter op borsthoogte (DBH) en hoogte gemeten. De diameter van de bomen op borsthoogte $(1,3 \mathrm{~m})$ is gemeten door de omtrek met een meetlint te meten en deze door $n$ ( $\mathrm{pi}$ ) te delen. Deze metingen werden uitgevoerd om de drie bomen in dezelfde rij waar de bodembemonstering plaatsvond. De hoogte is geschat aan de hand van een simpele methode gebruikelijk in de bosbouw (Carron, 1968) genaamd het neuskruis. Hierbij wordt een stok met gestrekte arm geheven en wordt er naar achter of naar voren gelopen tot de boom volledig bedekt wordt. Cruciaal is dat de lengte van het oog tot de hand even lang is als de stok, dat de stok verticaal rechtop wordt gehouden en dat er stammen of takken boven het midden van de hoofdstam worden gemeten. Indien een stuk van de takken dat naar voren helt wordt gemeten kan er een grote fout ontstaan. Als de bovenkant van de hand op hoogte van de voet van de boom is en de bovenkant van 
de stok de boomtop bedekt kan de afstand van het oog tot de voet van de boom worden gemeten. Deze afstand geeft een schatting van de hoogte van de boom. Bij hazelnoten bemoeilijkt de afwezigheid van een verticale stam vanuit het midden deze meting. Door te schatten waar deze stam zich zou bevinden en door vanonder uitstekende takken te meten is er alsnog een benadering gemaakt. Bij de hazelnoten is in plaats van de DBH de diameter van de hoofdstam vlak onder de vertakking gemeten.

\subsubsection{Schatting biomassa in walnotengaarden}

Twaalf bomen van soortgelijke groeivorm en leeftijd zijn gemeten in de twee rijen waar de bodembemonstering is uitgevoerd om een schatting te kunnen maken van boven- en ondergrondse houtige biomassa. Van belang was hierbij ook het vermijden van randeffecten, dus een afstand van rond de 5 meter tot de randen van het perceel is bewaard. Voor de tweejarige walnotenbomen in Herveld is het volume bepaald als bij een cilinder en vervolgens vermenigvuldigd met de soort specifieke houtdichtheid van $0,51 \mathrm{~g} \mathrm{~cm}^{-3}$ (Jenkins et al., 2004) voor de gewone walnoot en een koolstofpercentage in hybride walnoten, gemeten in een ander onderzoek naar koolstofopslag in agroforestry (45\%; Cardinael et al., 2017). Aangenomen is dat alle onderdelen van de boom dezelfde houtdichtheid en hetzelfde koolstofpercentage hebben. Ook is aangenomen dat leeftijd van de bomen geen effect heeft op deze parameters. De bovengenoemde waarden voor houtdichtheid en koolstofpercentage zijn ook toegepast op de berekeningen van koolstofopslag voor de walnotengaard in Luttelgeest. In Luttelgeest is het volume van de walnoten berekend als bij een grote cilinder. Bij gebrek aan tijd en hulpmiddelen zijn de afsplitsende takken niet gemeten. Na vermenigvuldiging met het aantal bomen per hectare is het totaal aan bovengrondse houtige biomassa uitgedrukt in $\mathrm{C} \mathrm{Mg} \mathrm{ha-1}$. Ondergrondse biomassa is berekend via de formule die doorgaans gebruikt wordt voor bossen in gematigde klimaten (Cairns et al., 1997):

$$
\mathrm{RB}=e^{-1.3267+0.8877 \times \ln (A B)+0.1045 \times \ln (\text { Age })}
$$

Hierin is RB de totale biomassa van de wortels ( $\mathrm{Mg} \mathrm{C} \mathrm{ha-1}$ ), $\mathrm{AB}$ bovengrondse biomassa ( $\mathrm{Mg} \mathrm{C} \mathrm{ha-1),}$ en Age is de leeftijd van de boomgaard (jaren). Ln is de functie voor het natuurlijk logaritme.

\subsubsection{Schatting biomassa in de hazelnotengaarden}

In de hazelnotengaarden is naast de totale hoogte en de omtrek onder de splitsing ook aan de basis van de afsplitsende takken de omtrek gemeten. Het volume van deze takken is berekend als het volume van een kegel, waarbij de straal werd gebaseerd op de omtrek aan de basis. Het volume van de hoofdstam onder de splitsing is berekend als die van een cilinder. Vervolgens is vermenigvuldigd met de soort specifieke houtdichtheid $\left(0,51751 \mathrm{~g} \mathrm{~cm}^{-3}\right.$; Schütt et al., 1994) en met een gemiddeld koolstofpercentage voor hardhoutsoorten, bij gebrek aan een exact getal voor hazelnotenhout, van $48,41 \%$ (Lamlom \& Savidge, 2003). Ondergrondse biomassa is voor beide hazelnotengaarden evenzo via de eerdergenoemde vergelijking van Cairns et al. (1997) geschat. Het is wederom aangenomen dat alle onderdelen van de boom dezelfde houtdichtheid en hetzelfde koolstofpercentage hebben en dat leeftijd van de bomen geen effect heeft op deze parameters.

\subsection{Resultaten}

\subsubsection{Koolstofopslag in boven- en ondergrondse biomassa van de notenbomen}

Tabel 10 laat zien dat jaarlijkse accumulatie van koolstof het hoogst ligt in de hazelnotengaarden maar amper verschil van de 22-jarige walnotengaard in Luttelgeest. In de hazelnotengaard in Lelystad is deze $0,61 \mathrm{MgC} \mathrm{ha}^{-1} \mathrm{j}^{-1}$ en in Breedenbroek 0,63 $\mathrm{Mg} \mathrm{C} \mathrm{ha-1}^{-1}$. De walnotengaard in Luttelgeest accumuleert vrijwel hetzelfde, namelijk $0,60 \mathrm{Mg} \mathrm{C} \mathrm{ha-1}^{-1} \mathrm{j}^{-1}$ en heeft een beduidend lagere plantdichtheid dan de hazelnotengaarden. 
De walnotengaard in Herveld accumuleert 0,18 $\mathrm{Mg} \mathrm{Cha}^{-1} \mathrm{j}^{-1}$ maar is nog jong (2 jaar). De twee datasets van zes bomen verschilden significant in Breedenbroek en in Lelystad.

Tabel 10 Boom-parameters van 12 bomen per notengaard en koolstofopslag in biomassa.

\begin{tabular}{|c|c|c|c|c|}
\hline Plaats & Luttelgeest & Herveld & Breedenbroek & Lelystad \\
\hline Leeftijd en boomsoort & $22 \mathrm{j}$ Juglans regia & 2 j Juglans regia & 25 j Corylus avellana & $\begin{array}{l}22 \mathrm{j} \text { Corylus } \\
\text { avellana }\end{array}$ \\
\hline Gemiddelde boomhoogte $(\mathrm{cm})$ & $1023 \mathrm{~cm}$ & $265 \mathrm{~cm}$ & $661,92 \mathrm{~cm}$ & $530,5 \mathrm{~cm}$ \\
\hline $\begin{array}{l}\text { Gemiddelde diameter op } \\
\text { borsthoogte }(\mathrm{DBH} ; \mathrm{cm})\end{array}$ & $19,25 \mathrm{~cm}$ & $2,83 \mathrm{~cm}$ & $28,97 \mathrm{~cm}$ & $18,17 \mathrm{~cm}$ \\
\hline Boomvolume per hectare $\left(\mathrm{m}^{3} \mathrm{ha}^{-1}\right)$ & $41,51+-13,54$ & $0,91+-0,49$ & $48,97+-19,72$ & $42,21+-11,15$ \\
\hline Koolstofpercentage in hout (\%) & $45 \%$ & $45 \%$ & $48,41 \%$ & $48,41 \%$ \\
\hline $\begin{array}{l}\text { Gemiddelde koolstofopslag per } \\
\text { boom (Mg C) }\end{array}$ & $82,53+-25,06$ & $0,53+-0,26$ & $47,50+-19,13$ & $44,17+-13,22$ \\
\hline Two sample t-test & $\begin{array}{l}\text { Geen significant } \\
\text { verschil tussen } \\
\text { datasets }\end{array}$ & $\begin{array}{l}\text { Geen significant } \\
\text { verschil tussen } \\
\text { datasets }\end{array}$ & $\begin{array}{l}\text { Significant verschil } \\
\text { tussen datasets }\end{array}$ & $\begin{array}{l}\text { Significant verschil } \\
\text { tussen datasets }\end{array}$ \\
\hline $\begin{array}{l}\text { Koolstofopslag in bovengrondse } \\
\text { biomassa bomen ( } \mathrm{Mg} \mathrm{C} \mathrm{ha-1)}\end{array}$ & $10,23 \mathrm{Mg} \mathrm{C} \mathrm{ha}^{-1}$ & $0,25 \mathrm{Mg} \mathrm{C} \mathrm{ha-1}$ & $12,26 \mathrm{Mg} \mathrm{C} \mathrm{ha}^{-1}$ & $10,56 \mathrm{Mg} \mathrm{C} \mathrm{ha}^{-1}$ \\
\hline $\begin{array}{l}\text { Koolstofopslag in ondergrondse } \\
\left.\text { biomassa bomen ( } \mathrm{Mg} \mathrm{C} \mathrm{ha-1}^{-1}\right)\end{array}$ & $2,89 \mathrm{Mg} \mathrm{C} \mathrm{ha-1}$ & $0,11 \mathrm{Mg} \mathrm{C} \mathrm{ha-1}$ & $3,39 \mathrm{Mg} \mathrm{C} \mathrm{ha-1}$ & $2,95 \mathrm{Mg} \mathrm{C} \mathrm{ha-1}$ \\
\hline $\begin{array}{l}\text { Totale koolstofopslag in } \\
\text { biomassa bomen ( } \mathrm{Mg} \mathrm{C} \mathrm{ha-1)}\end{array}$ & $13,12 \mathrm{Mg} \mathrm{C} \mathrm{ha}^{-1}$ & $0,35 \mathrm{Mg} \mathrm{C} \mathrm{ha-1}$ & $15,64 \mathrm{Mg} \mathrm{C} \mathrm{ha-1}$ & $13,51 \mathrm{Mg} \mathrm{C} \mathrm{ha-1}$ \\
\hline $\begin{array}{l}\text { Accumulatiesnelheid koolstof in } \\
\left.\text { biomassa ( } \mathrm{Mg} \mathrm{C} \mathrm{ha-1} \mathrm{j}^{-1}\right)\end{array}$ & $0,60+-0,18$ & $0,18+-0,085$ & $0,63+-0,25$ & $0,61+-0,16$ \\
\hline
\end{tabular}

\subsection{Discussie}

\subsubsection{Koolstofopslag in boven- en ondergrondse biomassa}

De koolstofaccumulatiesnelheid gevonden op de walnotengaarden $\left(0,60 \mathrm{Mg} \mathrm{C} \mathrm{ha-1} \mathrm{j}^{-1}\right)$ is vergelijkbaar met de eerdergenoemde agroforestry-systemen in Frankrijk met een plantdichtheid van ongeveer

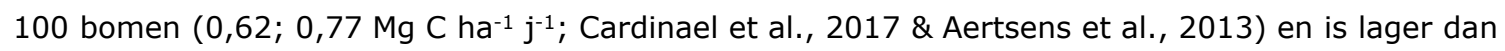
die van plantage met een hogere plantdichtheid $\left(0,92-4,67 \mathrm{Mg} \mathrm{C} \mathrm{ha-1}^{-1}\right.$; Jacobs et al., 2009; Zhang et al., 2017). Omdat voor walnoot uitsluitend het volume van de hoofdstam berekend is als bij een cilinder is echter waarschijnlijk dat er bij dit onderzoek een onderschatting is gemaakt van de totale koolstofopslag per walnotenboom. Bij vervolgonderzoek is het van belang dat het volume van de zijtakken wordt berekend en wordt nagegaan of het totale volume vergelijkbaar is in wat in andere studies of bij destructieve oogst van walnotenbomen is gevonden.

Verder is er, zoals eerder genoemd, geen andere literatuur beschikbaar over koolstofopslag in hazelnoten. Wel zijn als referentie voor een ander lopend onderzoek over koolstofopslag in hazelnotenteelt twee hazelnootbomen, een sterke groeier en een matige groeier, op het perceel in Breedenbroek geoogst. Hiervan is bovengrondse biomassa gewogen door de eigenaar. Hij gaf aan dat de sterke groeier een bovengronds gewicht van $268 \mathrm{~kg}$ had en de middelmatige groeier een van 197 $\mathrm{kg}$. Uitgaande van een vochtgehalte in het hout rond $30 \%$ van het gewicht, naar bewering van de eigenaar, komt het drooggewicht uit op 187,6 en 137,9 kg voor een sterke en een middelmatige groeier. Dit ligt rond tweemaal zo hoog als het boomgewicht dat via de methode in dit rapport is ingeschat. De verwachting is dan ook dat berekening van het volume van de zijtakken als bij kegels op een lager volume is uitgekomen dan in werkelijkheid aanwezig is. Voor vervolgonderzoek is van belang de methodiek aan te passen en mogelijk het volume van de lagere delen van de takken te berekenen als dat van cilinders en boven een bepaald punt die te berekenen als bij een kegel. Dit is vergelijkbaar met Cardinael et al. (2017). Tevens bestond er wat betreft koolstofopslag per boom een 
significant verschil tussen de gemeten boomstroken van zowel de hazelnotenboomgaarden in Breedenbroek als in Lelystad. Wat hieraan kan hebben bijgedragen is dat de biomassa van individuele bomen sterk verschilde per boomstrook. Ofwel de dimensies van meer dan twaalf hazelnotenbomen in meer dan twee stroken dienen te worden opgenomen bij vervolgonderzoek, of bomen dienen te worden geselecteerd op willekeurige wijze.

De koolstofaccumulatiesnelheid in de walnoten- en hazelnotengaarden is een stuk kleiner dan de 3,2 Mg C ha-1 $\mathrm{j}^{-1}$ die in gemiddeld natuurlijk Nederlands loofbos wordt geaccumuleerd (Arets, 2018). De lage plantdichtheid op de notengaarden en de onderschatting van de biomassa per boom kunnen hier eveneens verklaringen voor zijn. Bovendien telde Arets (2018) koolstof in strooisel, dood hout en bodem ook mee, in tegenstelling tot wat we in dit onderzoek hebben gedaan. Anderzijds is de koolstof accumulatiesnelheid in notengaarden substantieel hoger dan die van de gemiddelde eenjarige teelt $\left(-0,83 \mathrm{Mg} \mathrm{C} \mathrm{ha-1}^{-1}\right)$ in Europa (Vleeshouwers \& Verhagen, 2002).

Voor vervolgonderzoek zou de destructieve oogst van een aantal bomen betrouwbare resultaten geven over totale biomassa, koolstofgehalte en houtdichtheid. De kans is klein dat dit op veel van de notengaarden mogelijk is. Wel wordt regelmatig uitgedund door de notentelers. Mogelijk kan er op zulke momenten toch informatie over belangrijke parameters worden gemeten. Als dit niet mogelijk is, levert de eerder besproken methode van Cardinael et al., 2017 een inschatting van koolstofopslag in biomassa. Indien het doel is een groeicurve voor walnoot en de koolstofaccumulatie te bepalen, en op basis hiervan een model te maken, is het ook van belang dat er meerdere $(>10)$ walnotengaarden met oplopende leeftijden worden onderzocht of dat modelgewassen worden gevonden met representatieve boomdichtheden en opbrengsttabellen. Dit laatste heeft ook nadelen omdat modelgewassen vaak gecultiveerd worden op veel hogere plantdichtheden. Verder wordt aangeraden een andere methodiek toe te passen om de hoogte en de diameter van de bomen te meten dan het neuskruis en het meetlint om de betrouwbaarheid te verbeteren. Voor de hoogte kunnen bijvoorbeeld een boomhoogtemeter of een laser-scanner en een clinometer worden gebruikt (Larjavaara \& MullerLandau, 2013). Voor de omtrek is een digitale klem handig.

\subsubsection{Koolstofopslag in bodem}

Hoewel dit deelonderzoek geen berekeningen van koolstofopslag in de bodem in notengaarden heeft opgeleverd, in verband met de omissie van datalevering van het laboratorium, is het waarschijnlijk dat de uitkomst niet representatief zou zijn voor het gemiddelde bodemorganische koolstofgehalte op de boomgaard. Dit heeft te maken met de drie locaties waar bemonsterd is. Voor vervolgonderzoek wordt aangeraden dichterbij de bomen te bemonsteren. Naar zeggen van Cardinael et al., 2017 over hun protocol, zou bemonstering gesimplificeerd kunnen worden door uitsluitend te bemonsteren voor de boom of langs een diagonaal over het rechthoekige bemonsteringspatroon door hen toegepast. Het verdient ook aanbeveling om boomgaarden te bemonsteren die uitsluitend bestaan uit walnoot of hazelnoot, zodat effecten van andere gewassen, zoals in Luttelgeest, niet worden meegenomen.

\subsubsection{CO2-Fix en Yield-SAFE}

In dit deelonderzoek hebben we gekeken naar de meest relevante en toepasbare modellen voor het simuleren van koolstofopslag in boven- en ondergrondse biomassa en bodem (in paragraaf 5.4). Het modelleren zelf viel buiten de scope van het onderzoek.

Voordeel van het gebruik van CO2-Fix waarin het model van Yasso voor de bodem-module verwerkt is, lijkt dat het minder parameters nodig zijn dan voor Yield-SAFE en RothC en gebruik van het model simpeler is omdat het in één programma is samengevoegd (Schelhaas, 2004). Keerzijde kan zijn dat het een minder accurate voorstelling geeft van de koolstofopslag. CO2-Fix wordt doorgaans toegepast om koolstofopslag in agroforestry-systemen, boomgaarden en natuurlijke bossen, recentelijk vooral buiten Europa, te modelleren (Negash \& Kanninen, 2015; Panwar et al., 2017; Rizvi et al., 2017). Verwacht wordt dat dit voor notengaarden in Nederland eveneens op gaat. Aan de andere kant blijkt uit literatuur dat Yield-SAFE in Europa recentelijk meer adoptie en toepassing vindt voor koolstofopslag in agroforestry-systemen (Crous-Duran et al., 2019). Yield-SAFE biedt mogelijk een accuratere voorstelling van koolstofopslag, echter er is geen vergelijking in de literatuur beschikbaar die dit onderbouwt. Bijgevolg is de aanbeveling om koolstofopslag in de notengaarden via beide modellen te modelleren en de uitkomsten te evalueren met data over de koolstofvoorraad op langere 
termijn verworven uit eigen onderzoek of uit literatuur uit gematigde regio's. Zodoende kan zelf worden bepaald welk model de werkelijkheid het dichtst benadert.

\subsection{Aanvullende opmerkingen}

Voor vervolgonderzoek dient in overweging te worden genomen of modellering van koolstofopslag waardevoller is dan uitbreiding van onderzoek in bestaande notengaarden. Zoals genoemd vereist modellering met CO2-Fix of Yield-SAFE sets van relatief gedetailleerde parameters. In plaats van de diepte in te gaan voor een beperkt aantal notengaarden kan kwantificatie van koolstofopslag in meerdere Nederlandse notengaarden relevanter zijn voor de klimaatopgave. Op deze manier kan namelijk met een beperkt budget een meer betrouwbare en voor Nederland representatieve koolstofaccumulatiesnelheid in bodem en biomassa worden bepaald. De Nederlandse literatuur over koolstofopslag in notenbomen is beperkt. Daarom is het overgrote deel van de literatuur gebruikt in dit rapport uit het buitenland afkomstig. Er is geselecteerd op onderzoek in gematigde klimaatstreken als Nederland. Alsnog kunnen grote klimatologische en bodemkundige verschillen een rol spelen. Voor de verkenning van de methodiek heeft dit echter weinig consequenties.

\subsection{Conclusie en aanbevelingen}

Houtige meerjarige gewassen zoals walnoten- en hazelnotenbomen kunnen een bijdrage leveren aan klimaatmitigatie door koolstof te accumuleren in boven- en ondergrondse biomassa en bodem. In Nederland was niet bekend hoe groot deze bijdrage op hectare-basis kan zijn en is het in het belang van de klimaatopgave om mitigatiemethoden te verkennen. Dit onderzoek trachtte de uitgangssituatie te bepalen van koolstofopslag in twee Nederlandse walnoten- en twee hazelnotengaarden en verkende de methodiek om in vervolgonderzoek tot een betere kwantificatie te kunnen komen via additionele verzameling van data en modellering. Een walnotengaard van 25 jaar en twee hazelnotengaarden van 22-25 jaar accumuleerden gemiddeld rond de 0,61 $\mathrm{Mg} \mathrm{Cha}^{-1} \mathrm{j}^{-1}$ in boven- en ondergrondse biomassa. Verwacht wordt dat dit een onderschatting is van de koolstofopslag en dat na aanpassing van de methodiek de mate van koolstofopslag beter kan worden benaderd.

Wat betreft modellering is het onzeker of CO2-Fix of Yield-SAFE de werkelijke situatie het dichtst benadert en daarom wordt aangeraden om beide toe te passen in een nader uit te voeren modelleringsstudie, en op basis van data uit destructieve oogst of vergelijkbare onderzoeken de uitkomsten te valideren. Nadeel van modellering is dat er veel specifieke parameters voor nodig zijn. Bij een beperkte hoeveelheid geld en tijd lijkt het relevanter om het onderzoek uit te breiden naar meerdere boomgaarden van verschillende leeftijden om zodoende een meer betrouwbare schatting van de koolstofaccumulatiesnelheid voor notengaarden in Nederland te kunnen maken. Hiermee wordt de variatie in lokale omstandigheden en beheer van notengaarden beter meegenomen. 


\section{Economie}

\subsection{Inleiding}

Oosterbaan (2018) en door Baltissen (2018) hebben voor walnoot, resp. hazelnoot volgens KWIN normen (Heijerman-Peppelman en Roelofs, 2010) saldoberekeningen gemaakt. Voor deze berekeningen zijn nog niet voor alle kosten en opbrengsten normen beschikbaar. Daarom zijn enkel aannames gedaan. Hiervoor is gebruik gemaakt van informatie afkomstig van de leden van de Nederlandse Notenvereniging. De teelt van noten in Nederland vindt nog niet op grote schaal plaats, zodat dit de best beschikbare gegevens zijn voor Nederland. Deze gegevens zijn dan ook dankbaar gebruikt voor de berekeningen in dit hoofdstuk. In dit hoofdstuk zal eerst een toelichting op de gebruikte economische begrippen worden gegeven, vervolgens zal zowel voor walnoot als voor hazelnoot voor een aantal aspecten een gevoeligheidsanalyse worden gedaan. Daarnaast wordt gekeken naar het effect van ondergroei bij walnoot op het saldo.

\subsection{Gebruikte economische begrippen}

Een saldo wordt meestal berekend voor een jaar dat een boomgaard vol in productie is. Een saldo wordt berekend uit de opbrengsten (productie * prijs) minus de toegerekende kosten. De toegerekende kosten zijn alle kosten die direct zijn toe te rekenen aan een bepaald jaar van de aanplant en die in dit zelfde jaar worden verbruikt. Het zijn de kosten voor materialen, zoals gewasbeschermingsmiddelen, afleveringskosten, hagelverzekering en rente omlopend vermogen (zie tabel 11, voor berekening). In een saldo worden geen arbeidskosten verrekend. De kosten voor de losse arbeid en de kosten na de oogst voor opslag, drogen en transport zijn echter een groot deel van de kostprijs.

In de fruitteelt wordt het grootste deel van de productie niet direct na de oogst verkocht, maar eerst voor langere tijd bewaard. Daarom wordt er bij fruitgewassen gerekend met het marginaal saldo. Het marginaal saldo is het saldo minus de kosten voor losse arbeid voor de teelt, oogst en sorteren, de kosten voor transport en koeling en de rente omlopend vermogen na de oogst. Het lijkt logisch om bij noten dezelfde berekeningswijze te volgen. In tabel 11 wordt deze aanpak schematisch weergegeven. Het marginaal saldo rekent alleen met toegerekende kosten. Dat betekent dat van het bedrag van het marginaal saldo nog alle vaste kosten moeten worden betaald. Vaste kosten zijn niet specifiek toe te rekenen aan een bepaalde oogst, zoals de kosten voor de grond, vaste arbeid (zoals de kosten voor de ondernemer zelf), kosten voor duurzame productiemiddelen (machines zoals trekkers en werktuigen, maar ook drainage, erfverharding, gebouwen etc.) en de afschrijvingskosten van de plantopstand.

\subsection{Walnoot}

\subsubsection{Inleiding}

Op basis van de gegevens van Oosterbaan (2018) zijn volgens het rekenschema in tabel 11, berekeningen uitgevoerd voor het saldo en marginaal saldo. De gebruikte gegevens staan vermeld in bijlage 7 Het saldo voor een volwassenaanplant walnoot van het ras Broadview en plantdichtheid van 204 bomen per ha (plantafstand van $7 * 7$ meter) is daarmee berekend op $€ 9613$, terwijl het marginaal saldo $9067 € /$ ha bedraagt bij volle productie. Dit is een saldoberekening waarbij er geen rekening is gehouden met een tussengewas. Van dit saldo moeten alle vaste kosten (zoals de kosten van duurzame productiemiddelen, grond en vaste arbeid) nog betaald worden. Ook moet rekening gehouden worden met het feit dat dit berekende saldo pas geldt bij volle productie en dat is bij walnoot vanaf jaar 15 van de plantopstand (Oosterbaan, 2018). De opbrengstprijs waarmee gerekend is, is $4 € / \mathrm{kg}$ gedroogd. De prijs kan echter variëren er bestaan geen veilingprijzen en de meeste walnoten worden direct aan de consument verkocht. Oosterbaan (2018) gaat er vanuit dat alle arbeid door de ondernemer wordt uitgevoerd. In de berekening van het (marginaal) saldo betekent dit dat er 
helemaal geen kosten voor arbeid zijn meegenomen. Productie is sterk afhankelijk van ras, leeftijd, plantdichtheid en weersomstandigheden. Na de oogst worden de noten gedroogd en dit levert uiteraard gewichtsverlies op. Er is gerekend met een gemiddeld gewichtsverlies van 30\%, maar in de praktijk kan dit variëren van 25-50\% (Oosterbaan, 2018). Er is een gevoeligheidsanalyse gemaakt voor het effect van de prijs, hoeveelheid ingehuurde arbeid, productieverschillen en verschillen in gewichtsverlies door drogen. De resultaten hiervan worden in de volgende paragrafen een voor een weergegeven. De standaard gegevens zoals gebruikt voor de berekeningen staan in bijlage 7 .

Tabel 11 Rekenschema voor de berekening van saldo en marginaal saldo.

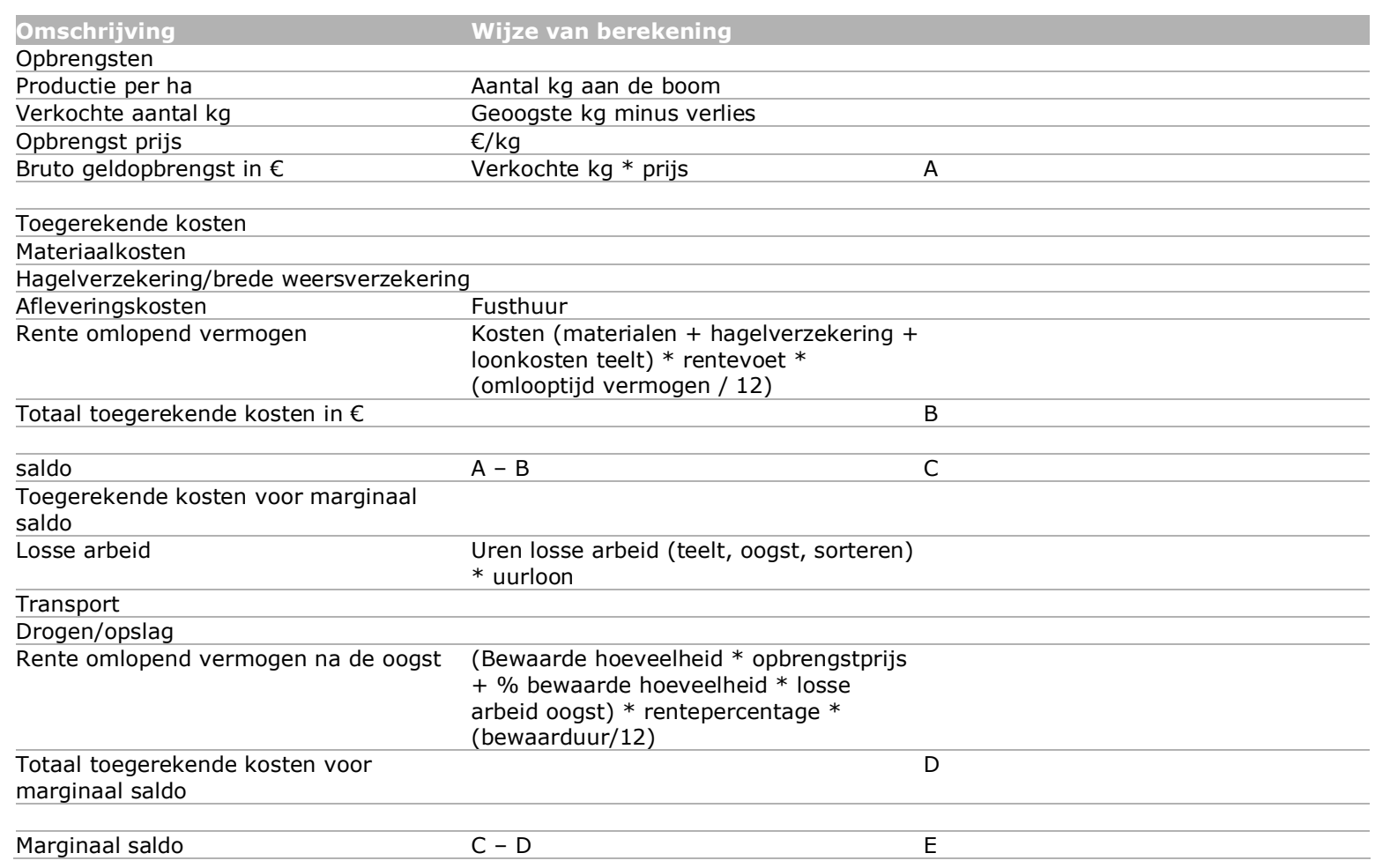

\subsubsection{Prijs}

Zoals Oosterbaan (2018) aangeeft zijn er geen veilingprijzen voor walnoten in Nederland. De huidige productie wordt veelal direct aan de consument geleverd, waarbij de prijzen variërentussen de 3 en $5 € / \mathrm{kg}$ voor gedroogde walnoten. In de standaard saldoberekening is uitgegaan van walnoten van het ras Broadview van $4 € / \mathrm{kg}$. In tabel 12 is weergegeven wat het effect is van een andere prijs. Een verandering van $25 \%$ in de prijs geeft een verandering van $30 \%$ in het marginaal saldo.

Tabel 12 Het effect van de prijs van een $\mathrm{kg}$ gedroogde walnoten op het marginaal saldo van walnoot(€/ha).

\begin{tabular}{lr} 
Prijs (e/kg) & Marginaal saldo (C/ha) \\
3,00 & 6.309 \\
\hline 3,50 & 7.688 \\
\hline $4,00=$ standaard & 9.067 \\
\hline 4,50 & 10.446 \\
\hline 5,00 & 11.825 \\
\hline
\end{tabular}

\subsubsection{Productie}

De productie in kilogrammen per hectare is sterk afhankelijk van het ras, de leeftijd van de opstand, plantdichtheid en uiteraard de weersomstandigheden. Gebaseerd op de ervaringen in de notenvereniging is voor de standaardberekeningen uitgegaan van een bruto productie (= vers opbrengst) van $4000 \mathrm{kilo} / \mathrm{ha}$. Bij nachtvorst kan de productie bijvoorbeeld tegenvallen. In tabel 13 is het effect van een $10 \%$ of $20 \%$ lagere respectievelijk hogere productie op het marginaal saldo. Het gaat hier om de bruto productie dus de kilo's vers geoogste noten. Een verandering van $20 \%$ in bruto productie geeft een verandering van $23-24 \%$ in het marginaal saldo. 
Tabel 13 Het effect van de productie $(\mathrm{kg} / \mathrm{ha})$ op het marginaal saldo van walnoot (€/ha).

\begin{tabular}{lc} 
Productie & Marginaal saldo (C/ha) \\
$-20 \%$ & 6.969 \\
\hline$-10 \%$ & 8.018 \\
\hline Standaard = 4000 kg/ha) & 9.067 \\
\hline$+10 \%$ & 10.115 \\
\hline$+20 \%$ & 11.164 \\
\hline
\end{tabular}

\subsubsection{Gewichtsverlies}

Na de oogst worden de noten gedroogd. Door het vochtverlies en het uitsorteren van slechte kwaliteit blijven er netto minder kilo's over voor de verkoop. Het verschil tussen het bruto en netto gewicht varieert van 25 tot 50\% tarra. In de standaardberekeningen is uitgegaan van 30\% verlies. In tabel 14 staat het effect van een ander percentage vochtverlies. Een verandering van $5 \%$ in verlies geeft een verandering van ongeveer $749 € /$ ha in het marginaal saldo.

Tabel 14 Het effect van meer of minder verlies (vocht en kwaliteit) op het marginaal saldo van walnoot (€/ha).

\begin{tabular}{ll}
$\%$ vochtverlies & Marginal saldo e/ha \\
25 & 9.816 \\
\hline 30 = standaard & 9.067 \\
\hline 40 & 7.568 \\
\hline 50 & 6.070 \\
\hline
\end{tabular}

\subsubsection{Arbeid}

In een saldoberekening worden vaste kosten (waaronder dus vaste arbeid) niet meegenomen. Oosterbaan (2018) gaat ervan uit dat alle arbeid wordt verricht door vaste arbeid. Dit betekent dat van het marginaal saldo nog alle arbeidskosten moeten worden betaald (evenals alle andere vaste kosten zoals kosten voor afschrijvingen van machines en gebouwen, grond, boomgaard etc.). In tabel 15 zijn enkele voorbeelden gegeven voor situaties waarin arbeid geheel of gedeeltelijk wordt betaald. De standaard berekening gaat er vanuit dat de ondernemer zelf alle arbeid verricht, zowel voor de teelt als voor oogst en sorteren/drogen. Het oogsten en drogen moet in vrij korte tijd gebeuren. Bij grotere oppervlakten kan de hoeveelheid tijd dan beperkend worden. Stel dat $80 \%$ van het werk in die tijd door losse krachten wordt uitgevoerd, dan daalt het marginaal saldo tot $€ 8103 / \mathrm{ha}$ bij een uurloon van $20 €$ /uur en tot $7863 €$ /ha bij een uurloon van $25 €$ /uur.

Tabel 15 Het effect van arbeidskosten ( $€ /$ urr) op het marginaal saldo ( $€ / h a)$ van walnoot.

\begin{tabular}{lccc} 
& Uurloon vast & Uurloon los & Marginaal saldo \\
Standaard $=0 \%$ losse arbeid & 0 & 0 & 9.670 \\
\hline $80 \%$ oogst en sorteren $=$ los & 0 & 20 & 8.103 \\
\hline $80 \%$ oogst en sorteren $=$ los & 0 & 25 & 7.863 \\
\hline Alle arbeid $=$ losse arbeid & 0 & 20 & 5.600 \\
\hline Alle arbeid $=$ losse arbeid & 0 & 25 & 4.734 \\
\hline
\end{tabular}

\subsection{6 'Worse case'}

Standaard wordt uitgegaan van een productie van $4000 \mathrm{~kg} / \mathrm{ha}$ en een prijs van $4 € / \mathrm{kg}$, waarbij er $30 \%$ gewichtsverlies optreedt door het drogen. In het geval dat deze drie factoren alle drie tegenvallen, de productie slechts $3000 \mathrm{~kg} / \mathrm{ha}$ is, bij een prijs van $3 € / \mathrm{kg}$ en een gewichtsverlies van $50 \%$, dan is het marginaal saldo $2720 € / \mathrm{ha}$. $\mathrm{Er}$ is dan wel 112 uur arbeid voor teeltwerkzaamheden (Oosterbaan, 2018), 30 uur voor de oogst en 15 uur aan het sorteren en drogen besteed (bijlage 7). Dat betekent 157 uur arbeid die nog vergoed zou moeten worden uit het marginaal saldo, naast de vaste kosten voor duurzame productiemiddelen en de afschrijvingskosten voor de aanplant.

\subsubsection{Scenario: Gras als ondergewas}

Een mogelijkheid voor extra opbrengsten wordt gezien in de onderteelt van bijvoorbeeld gras. In de KWIN veehouderij 2018-2019, wordt aangegeven dat de kosten van een ha grasteelt op klei worden 
berekend op $1253 € /$ ha. Van deze kosten bestaat $€ 411$ uit kosten voor materialen (zaaizaad, meststoffen, gewasbescherming etc). De overige kosten zijn loonwerkkosten. Gras wordt echter niet geteeld voor de verkoop maar voor voeropbrengsten. $\mathrm{Er}$ is daarom alleen een vuistregel voor de opbrengsten (pers. mededeling M. de Haan, Wageningen Livestock Research): "een vuistregel die je zou kunnen hanteren is dat grasland ca 12 ton ds/ha opbrengt. Vervolgens zou je $€ 0.10$ per $\mathrm{kg}$ ds kunnen rekenen, dus totaal een opbrengst van $€ 1200$. Dat is ongeveer gelijk aan de kosten." Bij deze kosten is uitgegaan van volledig uitvoeren in loonwerk. Wanneer een deel zelf kan worden uitgevoerd zullen de uitgaven lager zijn dan de kosten en kun je als bedrijf een deel overhouden. Ook kunnen de grasopbrengsten natuurlijk variëren. Deze berekening is uitgegaan van een volledige hectare gras. Dat is in het geval van een onderteelt onder walnoot niet het geval. Dat zal betekenen dat het werk waarschijnlijk minder efficiënt zal kunnen gebeuren. Hierdoor zouden de kosten hoger worden. Een onderteelt van gras lijkt daarmee niet echt een bedrijfseconomische optie te zijn.

Discussie

Een walnootaanplant kent een zeer lange periode tot volle productie. Pas in het $15^{\mathrm{e}}$ groeijaar is de volledige productie bereikt. In het tiende jaar is de productie een kwart van de volle productie zoals in het vijftiende jaar (Oosterbaan, 2018). De stichtingsperiode eindigt wanneer de opbrengsten in een jaar hoger zijn dan de kosten. Het gaat hierbij om alle kosten, van aanplantkosten tot vaste en toegerekende kosten. Dit betreft dan ook de aanplantkosten en de vaste kosten. Op basis van de beschikbare gegevens is de verwachting dat in het zesde of zevende jaar het marginaal saldo positief is. Dat is dus nog niet het einde van de stichtingsperiode, omdat die pas eindigt als ook de andere kosten door de opbrengsten worden goed gemaakt. Het totaal aan kosten in de stichtingsperiode zijn de stichtingskosten en deze zullen moeten worden afgeschreven in de resterende levensduur van de aanplant. Ook deze kosten zullen nog van het marginaal saldo moeten worden betaald. Met de huidige gegevens is het niet mogelijk goede stichtingskosten te berekenen.

In de berekeningen voor het marginaal saldo, is geen rekening gehouden met kosten voor de afzet, naast de kosten voor de kisten. Ook voor de afzet zal arbeid nodig zijn evenals kosten voor marketing en reclame.

\subsection{Hazelnoot}

\subsubsection{Inleiding}

Baltissen (2018) heeft de beschikbare gegevens voor een saldoberekening voor hazelnoot op een rij gezet. De gegevens zijn echter niet volledig, zodat er ook voor hazelnoot met aannames is gewerkt. Op basis van deze cijfers en in combinatie met gegevens van onderzoek uit 1997 (Joosse en Groot, 1997) zijn saldoberekeningen uitgevoerd. De gebruikte gegevens staan vermeld in bijlage 8 . De berekeningen geven een saldo aan van $8916 € /$ ha, en een marginaal saldo van $8366 € /$ ha bij volle productie. Dit geldt voor een aanplant vanaf het zevende groeijaar. Er is hierbij uitgegaan van een aanplant van 888 bomen per ha: enkele rij met plantafstand van 4,5*2,5 meter. Van een marginaal saldo moeten alle vaste kosten, zoals de kosten voor duurzame productiemiddelen, grond, vaste arbeid en ook de afschrijving van de aanplant nog worden betaald. Net als bij walnoot is arbeid niet meegerekend, omdat er vanuit gegaan is dat de ondernemer alle arbeid verricht. De productie is sterk afhankelijk van ras, leeftijd, plantdichtheid en weersomstandigheden. De prijs is daarnaast variabel, omdat het hier niet om een grote afzetmarkt gaat. Er zijn geen veilinggegevens. Er is daarom een gevoeligheidsanalyse gemaakt voor het effect van verschillen in prijs, productie, arbeidskosten op het marginaal saldo. De resultaten hiervan worden in de volgende paragrafen een voor een weergegeven. Daarnaast is onvoldoende bekend wat de oogst en droog/bewaarverliezen zijn. Ook dit is meegenomen in de analyse.

\subsubsection{Prijs}

Baltissen (2018) geeft aan dat notentelers de hazelnoten verkopen voor prijzen tussen de 3 en $5 € / \mathrm{kg}$. Het betreft noten in dop, geschoond, schuur gedroogd en niet gekraakt. Er is gerekend met een prijs van $4 € / \mathrm{kg}$. In tabel 16 is het effect van een andere prijs op het marginaal saldo weergegeven. 
Tabel 16 Het effect van de prijs van een $\mathrm{kg}$ hazelnoten op het marginaal saldo van hazelnoot $(€ / h a)$.

\begin{tabular}{lr} 
Prijs (e/kg) & Marginaal saldo (e/ha) \\
3,00 & 5.878 \\
\hline 3,50 & 7.122 \\
\hline 4,00 = standaard & 8.366 \\
4,50 & 9.610 \\
\hline 5,00 & 10.853 \\
\hline
\end{tabular}

\subsubsection{Productie}

De productiecijfers gaan uit van een productie van $2778 \mathrm{~kg} / \mathrm{ha}$, waarvan netto $2500 \mathrm{~kg}$ geschoonde en in de schuur gedroogde hazelnoten/ha. Het gaat daarbij om noten in dop. De productie is geen vaststaand gegeven, maar hangt af van verschillende factoren zoals het weer in het seizoen en bijvoorbeeld ziekten en plagendruk. Zo kan de hazelnotenboorder zorgen voor aantasting van de productie met als gevolg verliezen van 10-20\% van de bruto productie. In tabel 17 zijn de effecten op het marginaal saldo voor lagere en hogere productie weergegeven. Een $20 \%$ hogere of lagere productie leidt tot een $22.4 \%$ hoger respectievelijk $22.5 \%$ lager marginaal saldo.

Tabel 17 Het effect van de productie op het marginaal saldo van hazelnoot (€/ha).

\begin{tabular}{lr} 
Productie & Marginaal saldo (E/ha) \\
$-20 \%$ & 6.489 \\
\hline$-10 \%$ & 7.428 \\
\hline $2778 \mathrm{~kg} / \mathrm{ha}=$ standaard & 8.366 \\
\hline$+10 \%$ & 9.301 \\
\hline$+20 \%$ & 10.239 \\
\hline
\end{tabular}

\subsubsection{Arbeidskosten}

$\mathrm{Er}$ is vanuit gegaan dat alle arbeid door de ondernemer wordt verricht. Het zal van de bedrijfssituatie afhangen of dit ook bij grotere arealen is vol te houden. Ook als wel alles in eigen arbeidsuren kan worden gedaan, zal er ook in dat geval een goede vergoeding voor de arbeid nodig zijn. Er is daarom gerekend voor de situatie dat de arbeid geheel of gedeeltelijk door losse arbeid wordt verricht. Het marginaal saldo daalt dan uiteraard. Van het marginaal saldo moeten dan nog steeds de kosten voor duurzame productiemiddelen (vaste arbeid, grond, aanplant, machines) worden vergoed.

Tabel 18 Het effect van arbeidskosten ( $€ /$ uur) op het marginaal saldo ( $€ /$ ha) van hazelnoot.

\begin{tabular}{lccc} 
& Uurloon vast & Uurloon los & Marginaal saldo \\
Standaard $=0 \%$ losse arbeid & 0 & 0 & 8.366 \\
\hline $80 \%$ oogst en sorteren $=$ los & 0 & 20 & 8.044 \\
\hline $80 \%$ oogst en sorteren $=$ los & 0 & 25 & 7.964 \\
\hline Alle arbeid $=$ losse arbeid & 0 & 20 & 6.772 \\
\hline Alle arbeid $=$ losse arbeid & 0 & 25 & 6.374 \\
\hline Alle arbeid $=$ losse arbeid & 0 & 30 & 5.975 \\
\hline
\end{tabular}

\subsection{5 'Worse case'}

Bij toename van de productie van hazelnoot in Nederland stijgt het aanbod en zou de prijs kunnen dalen. Als daarbij komt dat de productie minder is dan de hier aangenomen hoeveelheid van netto $2500 \mathrm{~kg} / \mathrm{ha}$, door tegenvallers in de teelt, zal het marginaal saldo dalen. Bij een $20 \%$ lagere productie en een prijs van $3 € / \mathrm{kg}$ is het marginaal saldo $4499 € / \mathrm{ha}$. Er is dan van uit gegaan dat alle arbeid door de ondernemer wordt gedaan. De 59 teelturen (zie bijlage 8) plus de oogsturen zullen nog vergoed moeten worden uit dit marginaal saldo plus de kosten voor duurzame productiemiddelen.

\subsubsection{Discussie}

Hoewel een hazelnootaanplant een kortere periode tot volle productie kent dan walnoot, is de aanloopperiode nog steeds een flink aantal jaar. Pas in het zevende jaar wordt van een volle productie uitgegaan. Op basis van de beschikbare gegevens is na het tweede of derde jaar het saldo positief. Dat is echter nog niet het einde van de stichtingsperiode, omdat die loopt totdat de opbrengsten 
groter zijn dan de kosten (zowel aanplantkosten, vaste kosten als toegerekende kosten). De kosten van de stichtingsperiode zullen moeten worden afgeschreven in de overige jaren van de levensduur van de aanplant.

Op dit moment zijn er te weinig gegevens om een goede berekening van de stichtingskosten te kunnen maken. In 1997 (Joosse en Groot) is wel de annuïteit netto contante waarde berekend van een hazelnootaanplant met 1000 bomen/ha, een productie van $3500 \mathrm{~kg} / \mathrm{ha}$ en $10 \%$ oogstverlies en loze noten. Door een annuïteit netto contact waarde te berekenen kan een meerjarig gewas financieel vergeleken worden met een eenjarig gewas. De annuïteit contante waarde ligt lager dan het saldo in een vol productief jaar, omdat ook de saldi van de beginjaren plus de aanlegkosten worden meegenomen in deze berekening. Toen was de conclusie dat de jaarannuïteit van hazelnoten hoger is dan het saldo van een aantal belangrijke akkerbouwproducten. Alleen het saldo van aardappelen en suikerbieten was toen hoger dan de jaarannuïteit van hazelnoot. De jaarannuïteiten van enkele fruitgewassen waren destijds hoger dan de jaarannuïteit van hazelnoot, maar het verschil was in sommige gevallen niet groot. Om deze berekening nu te kunnen maken zijn meer gegevens nodig.

\subsection{Algemene conclusie}

In dit hoofdstuk zijn saldoberekeningen gemaakt. Zoals eerder genoemd worden daarin vaste kosten niet meegenomen. Dit geeft een beperking van de bruikbaarheid. Een volledige kostprijsberekening zou op dit moment echter gebaseerd zijn op te veel aannames. Deze aannames zijn zowel voor kosten specifiek voor de notenteelt, maar ook gegevens rondom andere bedrijfskosten. Wanneer de notenteelt groter wordt in Nederland, is het wellicht mogelijk om voor meer kostenposten goede normen te berekenen. Bij een saldo is het wel mogelijk meerjarige teelten onderling te vergelijken, als zij tenminste een gelijke levensduur en stichtingsperiode kennen. Voor gewassen met aanplanten van verschillende levensduur, is om een goede vergelijking te kunnen maken de berekening van de annuïteit netto contante waarde nodig. 


\section{Communicatie en samenwerking in de notenketen}

\subsection{Inleiding}

Eén van de projectdoelstellingen van het notenproject is communicatie en verkenning van de samenwerking in de notenketen. Dit hoofdstuk gaat in op de activiteiten die in het kader van de communicatie door het projectteam zijn ondernomen, bediscussieert de (huidige samenwerking in) de notenketen en markt en doet aanbevelingen voor verdere verkenningen.

\subsection{Communicatie en netwerkvorming}

Voor dit projectonderdeel is nauw samengewerkt met de Nederlandse Notenvereniging. De uitwisseling van kennis en ervaringen tussen stakeholders in de notenketen is belangrijk voor de stimulering van de notenteelt in Nederland. De samenwerking is o.a. tot uiting gekomen door een presentatie van het projectteam op een bijeenkomst die door de Nederlandse Notenvereniging was georganiseerd op 10 november 2018 (zie onder 'Kennisoverdracht Nederlandse Notendag'), en door deelname aan een bijeenkomst van Projecten LTO Noord (waar ook de voorzitter van de Nederlandse Notenvereniging bij betrokken was) op 13 december 2018 (zie onder 'Informatieverstrekking op bijeenkomst van Projecten LTO-Noord'). Daarnaast heeft gedurende de looptijd van het project zeer frequent overleg plaatsgevonden tussen de voorzitter van de Nederlandse Notenvereniging (dhr. A.H.M.C. Baltissen) en de projectcoördinator (dhr. H. van Reuler). Aangezien reeds een groot aantal spelers uit de Nederlandse notenteelt aangesloten is bij de Nederlandse Notenvereniging (41 leden per juli 2018, waaronder notentelers en verwerkers) is het logisch dat het projectteam de verspreiding van projectresultaten samen doet met de Notenvereniging. Bij het schrijven van dit rapport (januari 2019) heeft nog geen verspreiding van projectresultaten plaatsgevonden; echter, het rapport zal o.a. via de website van de Nederlandse notenvereniging worden ontsloten.

\subsubsection{Kennisoverdracht en netwerkvorming op de Nederlandse Notendag}

Op zaterdag 10 november 2018 vond de eerste Nederlandse Notendag plaats op het bedrijf Mobipers in Zoelen. Deze Notendag werd georganiseerd door de Nederlandse Notenvereniging. Op de locatie in Zoelen waren verschillende rassen walnoten te zien evenals een machine voor het kraken van walnoten en een pers voor de productie van walnoten- en hazelnotenolie. Er werden verschillende rassen walnoten en hazelnoten getoond die ook geproefd konden worden. Het programma (Bijlage 9) bestond verder uit enkele presentaties en workshops. Eén van de presentaties werd verzorgd vanuit onderhavig project (Bijlage 10) waarbij een aantal highlights werden gepresenteerd die op dat moment beschikbaar waren. Ook werd een oproep gedaan aan notentelers voor medewerking aan het koolstofopslag onderzoek.

Er waren ca. 40 personen aanwezig bij de presentatie. De discussie ging met name over de economische haalbaarheid van notenteelt. Er werd o.a. gezegd dat er nog weinig professionele notentelers zijn die hun hoofdinkomsten uit de notenteelt halen.

Op 13 december 2018 organiseerde Projecten LTO-Noord een kennisavond 'Notenteelt, iets voor u?' voor agrarisch ondernemers rond Hengelo. De belangstelling voor deze bijeenkomst was zo groot dat de organisatie besloten heeft om de bijeenkomst op een later tijdstip te herhalen en om dezelfde soort bijeenkomsten te organiseren verspreid over het land. Het programma bestond uit diverse lezingen over de opstart van een notenplantage, de teelt, de afzet, verschillende toepassingen van notenbomen (in bv bufferstroken of agroforestry systemen) etc. en uit het delen van praktijkervaringen door een notenteler en een notenkweker. Vanuit huidige project is een informatiesheet uitgedeeld aan de (ca. 80) aanwezigen. Hierin wordt weergegeven wat het project inhield en wat er is onderzocht (Bijlage 11). 


\subsubsection{Spelers in de notenketen en huidige afzetkanalen}

De notenketen is reeds in kaart gebracht door Baltissen et al. (2017). Deze studie geeft aan dat de notenketen in Nederland voor Nederlandse noten uit de volgende schakels bestaat: boomkweker (veredelt, kweekt en verkoopt bomen); teler (produceert noten); verwerker (ver- en bewerkt noten); tuincentrum (verkoopt notenbomen, vaak kleine maten); verkoper noten (handelt in en verkoopt noten aan de retail); consument (koopt bomen, noten en/of notenproducten). Sommige spelers zijn actief in meer dan een onderdeel van de keten.

De huidige Nederlandse notentelers hebben allemaal hun eigen afzetkanalen. Baltissen et al. (2017) geeft aan dat de afzet varieert van huisverkoop tot aan verkoop aan een lokale banketbakker; een enkeling verkoopt aan een chocoladefabriek. Volgens een andere bron, Dhr. H. Janssen (pers. mededeling): "De in Nederland geteelde noten worden vrijwel allemaal afgezet door directe verkoop of via boerderijwinkels." De notentelers die we in het kader van het onderzoek naar koolstofopslag hebben gesproken geven aan dat zij de notenoogst grotendeels rechtstreeks aan consumenten verkopen.

Beide bronnen (Baltissen et al., 2017 en Dhr. H. Janssen, pers. mededelingen) zijn het erover eens dat de in Nederland geproduceerde noten grotendeels ongekraakt worden verkocht. Een deel wordt tot olie verwerkt. Ook worden andere producten gemaakt van noten of de notenschil (denk aan kleurstof, tinctuur en bijvoorbeeld straalgrit) en deze worden afgezet via regionale kanalen van beperkte omvang, aldus Baltissen et al. (2017). Centrale punt in de verwerking van Nederlandse noten tot olie is volgens dhr. Janssen het bedrijf Mobipers. Mobipers doet de verwerking van noten van telers als loonwerk, of koopt noten in voor eigen distributie (bijvoorbeeld verkoop aan Landwinkels). In België zijn er ook nog enkele verwerkers waar Nederlandse notentelers hun noten aan verkopen of laten verwerken (ten tijde van het onderzoek, in 2018, kwam bijvoorbeeld 'De Mobiele Fruitpers' naar voren bij een internet zoekopdracht).

Het grootste deel van de noten die in Nederland verkocht of verwerkt worden zijn echter afkomstig uit het buitenland. Spelers zijn Nederlandse importeurs (zoals Finma BV, Intersnack), groothandel, horeca, industrie, detailhandel en verwerkers. De hazelnoten die gebruikt worden door retailers zijn grotendeels direct afkomstig uit Turkije of worden via Nederlandse groothandels gekocht (SOMO, 2010). Dhr. H. Janssen bevestigt dat $98 \%$ van het volume bestaat uit geïmporteerde noten. De Notitie Notenteelt in Nederland (2017) geeft aan dat Nederland ook een belangrijk doorvoerland van noten is.

\subsubsection{Opschaling Nederlandse notenteelt en marktkansen}

Baltissen et al. (2017) geeft aan dat uitbreiding van de Nederlandse notenteelt kansrijk is om de volgende redenen:

- Notenteelt is een duurzame teelt en draagt bij aan verduurzaming van de bodem en verbetering van de grond- en oppervlaktewaterkwaliteit;

- Notenteelt draagt bij aan landschappelijk waarden;

- Notenteelt verhoogt de biodiversiteit;

- Noten eten is gezond en noten staan in de schijf van vijf;

- Notenteelt draagt bij aan de transitie van dierlijk naar plantaardig eiwit;

- Notenteelt zorgt voor (tijdelijke) vastlegging van koolstof;

- Na de teelt van walnoten is het walnotenhout een kostbaar product. Dit zorgt voor nog langere koolstofvastlegging.

Wat betreft marktkansen voor de in Nederland geteelde noten geeft Baltissen et al. (2017) aan dat voor grootschalige afzet de concurrentie met het buitenland hoog is (i.v.m. arbeidskosten en grondprijzen die in het buitenland lager liggen). De grootste kansen zijn er voor kleinschalige- tot middelgrote bedrijven met directe, lokale afzet (local for local, biologisch en duurzaam). De markt stelt hoge eisen aan de kwaliteit van de noten (conclusies vanuit studentenrapport Visser et al. 2016). Baltissen geeft via de website van stichting CropEye (een stichting die als kennismakelaar, kennisontwikkelaar en innovatieregisseur opereert in de agribusiness) ook aan dat een eigen Nederlands gepositioneerde productie prima kan aansluiten bij de reeds bestaande keten van verwerking (in Nederland worden heel veel noten verwerkt, die hoofdzakelijk via de haven van Rotterdam het land binnenkomen). 
De geïnterviewde adviseur, dhr. Janssen, geeft aan dat alle elementen aanwezig zijn om van de uitbreiding van het teeltvolume van in Nederland geteelde noten een succes te maken. Bij de opschaling van de Nederlandse notenteelt gaat het volgens dhr. Janssen om het maximaliseren van de opbrengst (vergroten van het volume) en professionalisering (verhoging van de kwaliteit). Hierbij is kennisuitbreiding van optimale teeltcondities (up-to-date teeltbeschrijvingen) en rassenkeuze onontbeerlijk. Ondernemers die met de teelt van noten aan de slag willen moeten weloverwogen keuzes kunnen maken. Zij moeten volgens hem een beslissing kunnen nemen voor welk doel ze gaan produceren; voor de smaak van de noot bedoeld voor rechtstreekse consumptie, of voor de productie van notenolie?

In de promotie van de notenteelt moet je daarnaast garantie kunnen geven dat je weet hoe de keten in elkaar zit, en dat afzet en verwerking op orde is op het moment dat nieuwe telers willen instappen. Het duurt immers even na de aanplant voordat deze nieuwe telers kunnen oogsten, maar je moet deze nieuwe telers wel al perspectief bieden. Er zal bijvoorbeeld een coöperatie moeten worden opgezet van telers en verwerkers waarbij ook aan kwaliteitsnormen gewerkt gaat worden (bijvoorbeeld een keurmerk voor de Nederlandse noot? Of specifiek voor de biologische geteelde noot?). Die kwaliteitsnormen zijn er nu nog niet. Dit zal gepaard moeten gaan met promotie en marketing. De Nederlandse noot die voldoet aan kwaliteitseisen zal duurder zijn dan de geïmporteerde noot, maar zal over het algemeen een ecologische en landschappelijke meerwaarde hebben. Hier zal je de consument in mee moeten nemen, dus grotere vraag moeten creëren, aldus dhr. Janssen.

In de huidige bestaande teelt ziet hij dat er een professionaliseringslag gaande is. Uitbreiding in de thuisverwerking bijvoorbeeld, door telers die professionele droogapparatuur, kraakinstallaties en oliepersen hebben aangeschaft of op het punt staan deze aan te schaffen.

\subsection{Discussie}

Wat betreft opschaling van de Nederlandse notenteelt zijn er signalen dat de belangstelling voor notenteelt toeneemt. Het ontbreekt echter aan cijfers over de toename van het areaal. Volgens de Nederlandse Notenvereniging is er zeker recent 30 ha aangeplant. Hetzij als monocultuur of in agroforestry-verband. Er zouden meer noten worden geteeld dan dat je op basis van de CBS gegevens zou mogen verwachten. Met andere woorden: veel land met bomen staat niet geregistreerd als notenteelt (in 2018). Er kan gesproken worden van een groeiende notenproductie in de komende jaren. De vraag is of al die noten rechtstreeks afgezet kunnen worden in bestaande korte ketens, of zullen er nieuwe ketens en afzetkanalen moeten worden ontwikkeld?

Als uitgegaan wordt van het feit dat de Nederlandse noot die voldoet aan kwaliteitseisen duurder zal zijn dan de geïmporteerde noot zal via consumentenonderzoek moeten worden onderzocht welke meerprijs de consument bereid zou zijn te betalen. Uit eerder onderzoek van de WUR (http://edepot.wur.nl/254609) blijkt dat consumenten tot $8 \%$ meer willen betalen voor lokale producten. Gaan de Nederlandse notentelers het daarmee redden? Zijn eventuele andere waarden als duurzaamheid en landschap genoeg om de Nederlandse consument meer te laten betalen? Zou wellicht beter ingezet kunnen worden op smaak en kwaliteit en de Nederlandse noten zodat deze gebruikt kunnen worden in luxere (chocolade)producten waar meer marge op gemaakt kan worden? Wat dat betreft is het ontbreken van kwaliteitsnormen zorgelijk. Daar zou nu al op ingezet moeten worden.

Het is aan te bevelen dat er een verkenning uitgevoerd wordt naar de mogelijkheden om de marge op notenproducten te vergroten (ofwel: onderzoek naar optimale verwaarding van noten). Een voorbeeld van optimale verwaarding van een boerderijproduct is boerderij-ijs. Via het concept Boerderij-ijs kunnen boeren een hogere prijs voor hun melk en/of fruit vragen. Boeren kopen hun eigen ijsmachine en smaakpoeders en produceren zelf boerderij-ijs met melk van eigen koeien, aangevuld met verse producten (fruit). Wellicht is het voor een (toekomstige) notenteler interessant om in zijn of haar omgeving (boeren)ijsmakers te bezoeken om te vragen of ze met zijn of haar hazelnoten ijs willen maken? 
Binnen de multifunctionele landbouw is veel onderzoek gedaan, ook naar optimale productverwaarding van boerderijproducten. Zo wordt door Vijn et al. geconcludeerd dat optimale verwaarding door een aantal factoren wordt bepaald:

- Het ras en de kwaliteit van het product;

- Het samenspel tussen de ondernemer en de verwerker, om uit elk boerderijproduct een optimaal assortiment te maken voor de klanten van die boerderij;

- Een goede kennis van de klantenkring, om de vraag vanuit de markt te vertalen naar het

- aanbod van producten tegen een passende prijs;

- Een slimme communicatie met de klantenkring, om het aanbod van producten vlot af te kunnen zetten en daar de openingstijden van een eventueel aanwezige boerderijwinkel en het transport efficiënt op aan te passen;

Daarnaast concludeert Vijn et al. (2014) dat goede marketing en communicatie en een gericht benaderen en opbouwen van een klantenbestand noodzakelijk is om de verkoop van steekproducten goed rendabel te maken. Dit moet een ondernemer wel 'in huis' hebben: directe afzet aan de consument vergt verschillende vaardigheden van de ondernemer. Ook hier is binnen de multifunctionele landbouw onderzoek naar gedaan. Veen et al. (2011) schrijft: 'Succesvolle verbreding vraagt veel van het ondernemerschap. De ondernemer moet goed kunnen communiceren, snel inspelen op nieuwe kansen, takken in het bedrijf met elkaar verbinden, potentiële doelgroepen zoeken, zelf zijn markt organiseren en kunnen netwerken.' Dit gaat uiteraard niet vanzelf en een ondernemer die overweegt om te starten met notenteelt met als doel om zijn/haar product af te zetten rechtstreeks aan de consument zal goed bij zichzelf te rade moeten gaan of hij of zij die vaardigheden bezit of bereid is die te gaan ontwikkelen.

\subsubsection{Aanbevelingen}

- Diverse voorbeelden vanuit aanverwante landbouwsectoren laten zien dat het zeer lonend kan zijn om energie te stoppen in afzet via directe verkoop. Dit gaat echter niet vanzelf. Er zullen marktpartijen moeten opstaan die kansen zien voor productverwaarding en afzetvergroting. De notensector zal er actief mee aan de slag moeten om marktpartijen te doen aanhaken.

- Het is aan te bevelen om samen met de notensectorpartijen een gedetailleerde verkenning te doen naar marktkansen. Hierbij is het goed om onderscheid te maken in kansen voor bewerkte noten en onbewerkte noten en in directe verkoop en indirecte verkoop. Ondernemers die nu willen beginnen met de aanplant van bomen (hazelaars en walnotenbomen) hebben baat bij meer inzicht in de marktkansen voor de verschillende producten en manieren van afzet, zie figuur 8.1 . 


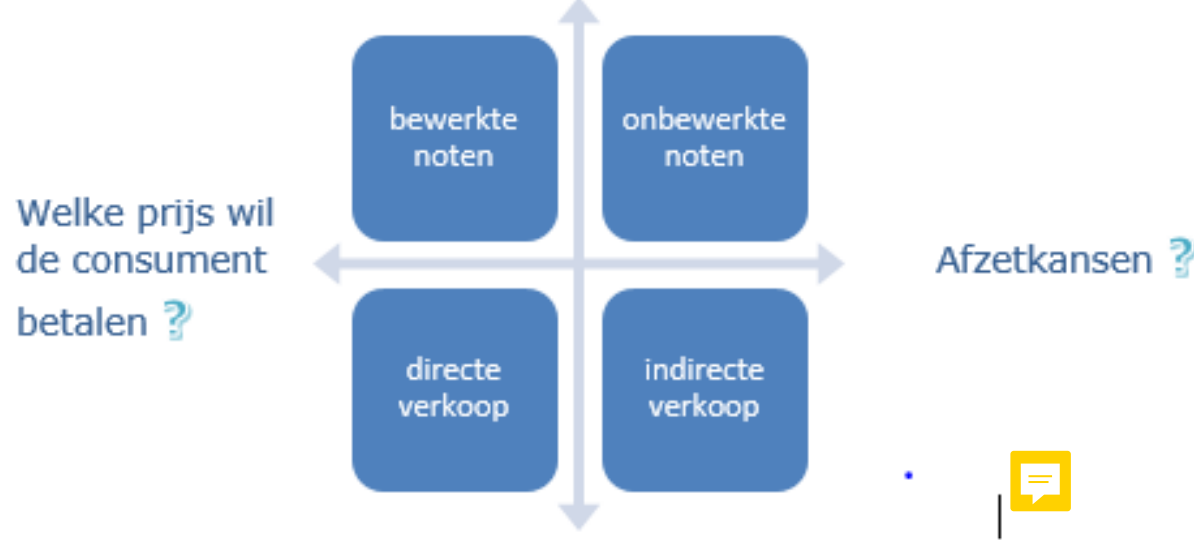

\section{Wat wil de consument?}

Figuur 8.1 De notensector heeft behoefte aan meer inzicht in afzetmogelijkheden voor noten(producten) en mogelijke opbrengsten.

- Het is aan te bevelen om een consumentenonderzoek te doen voor Nederlandse noten en notenproducten, zodat meer inzicht gecreëerd wordt in de bereidheid van consumenten om een meerprijs te betalen voor Nederlandse (kwaliteits)noten en notenproducten, zoals notenolie en voor noten die op een bepaalde manier zijn geproduceerd (onder voorwaarden van bijvoorbeeld een Fair Trade keurmerk) en met een bepaald doel (bijvoorbeeld verhoging landschappelijke waarde). 


\section{Slotopmerkingen}

$\mathrm{Er}$ is grote en brede belangstelling om noten aan te planten. De redenen hiervoor zijn divers. In de periode $1980-90$ is er veel onderzoek gedaan naar de mogelijkheden voor de teelt van noten in Nederland. Daarna heeft het onderzoek vrijwel stil gelegen. Er is behoefte aan onderzoek naar de geschiktheid van in het buitenland nieuw ontwikkelde rassen en onderstammen voor de teelt in Nederland.

$\mathrm{Er}$ is onderzoek nodig welke nieuwe teeltsystemen de rentabiliteit van de notenteelt in Nederland verhogen. Afhankelijk van het doel van de aanplant kan hierbij ook gedacht worden aan gebruik van zwak groeiende onderstammen zodat hoge plantdichtheden mogelijk zijn.

Noten kunnen een belangrijke rol spelen bij de tijdelijke opslag van koolstof. Er zijn alleen buitenlandse gegevens beschikbaar over de koolstofaccumulatie in de tijd van walnoten. De notenteelt bijdrage aan het bodem organische stofgehalte draagt \ bij aan de klimaatmitigatie, maar heeft ook landbouwkundige voordelen.

Voor de kwantificering van de bijdrage van noten aan de klimaatmitigatie is het nodig een aantal representatieve referentiepercelen (in notengaarden) over een lange periode te gaan monitoren.

Walnoten komen na ongeveer 15 jaar tot volledige productie en hazelnoten na ongeveer 6 jaar. De z.g. stichtingsperiode eindigt wanneer de financiële opbrengst hoger is dan de som van alle kosten. Het is economisch gezien belangrijk op welke wijze deze periode zo kort mogelijk kan worden gehouden.

De Nederlandse Notenvereniging is erg actief bezig om de notenteelt meer bekendheid te geven. De Vereniging brengt stakeholders uit de notenketen bij elkaar en biedt een platform voor uitwisseling van kennis en ervaringen. Er zal gewerkt moeten worden aan kwaliteitsborging. Voor optimale productverwaarding en afzetvergroting zullen (meer) marktpartijen moeten aanhaken. Ook is consumentenonderzoek aan te bevelen. 


\section{Referenties}

Achim, G., Botu, M. and Botu, I. (2007a). 'Portval' - a new walnut rootstock. Acta Hortic. 760, 549553.

Achim, G., Botu, M. and Botu, I. (2007b). Evaluation and propagation of walnut cultivars and rootstocks in the nursery. Acta Hortic. 732, 359-363.

Aertsens, J., De Nocker, L., Gobin, A. (2013). Valuing the carbon sequestration potential for European agriculture. Land Use Policy 31, 584-594.

Albert, K., Annighöfer, P., Schumacher, J., \& Ammer, C. (2014). Biomass equations for seven different tree species growing in coppice-with-standards forests in Central Germany. Scandinavian journal of forest research, 29, 210-221.

Aletà, N., Rovira, M., Ninot, A. and Vilanova, A. (2005). 'Chandler' walnut trees trained in three kinds of central leader: structured, semi-structured and free - Results at the age of six. Acta Hortic. 705, 479-485.

Arets, E. J. M. M. (2018). Klimaatcijfers voor natuur: Cijfers voor koolstofopslag en-vastlegging in Nederlandse natuur. Wageningen Environmental Research.

Baldwin, B. J. (2015). The growth and productivity of hazelnut cultivars (Corylus avellana L.) in Australia. University of Sydney. Faculty of Rural Management. Sydney Digital Theses.

Baltissen, A.H.M.C. \& A. Oosterbaan (2017). Notenteelt in Nederland. Een technisch economische haalbaarheidsstudie. Wageningen Plant Research (Bloembollen, Boomkwekerij \& Fruit) \& Wageningen Environmental Research. Rapport 2017-04.

Baltissen, A.H.M.C., M. van Leeuwen, H. Klinkert, G. Kleijer, X. San Giorgi, F. van Poppel. Notenteelt in Nederland (2017). Op weg naar een robuuste keten met in Nederland geteelde noten. Notitie van de Nederlandse Notenvereniging. Ongepubliceerd.

Barrios, E., Sileshi, G. W., Shepherd, K., \& Sinclair, F. (2012). Agroforestry and soil health: linking trees, soil biota and ecosystem services. Soil ecology and ecosystem services, 315-330.

Bignami, C. et al. (2004) Effect of high density and dynamic tree spacing on yield and quality of the hazelnut cultivar 'Tonda gentile Romana'. VI International Congress on Hazelnut 686.

Boosten, M., Jonge, A., Schelhaas, M. J., Nabuurs, G. J., Borgman, D., Kremers, J. (2018)

Gereedschapskist klimaatslim bosbeheer. Stichting Probos. http://edepot.wur.nl/462646

Botu, M., Tudor, M. and Papachatzis, A. (2010). Evaluation of some walnut cultivars with different bearing habits in the ecological conditions of Oltenia - Romania. Acta Hortic. 861: 119-126.

Cairns, M. A., Brown, S., Helmer, E. H., \& Baumgardner, G. A. (1997). Root biomass allocation in the world's upland forests. Oecologia, 111, 1-11.

Cambria, D., \& Pierangeli, D. (2012). Application of a life cycle assessment to walnut tree (Juglans regia L.) high quality wood production: a case study in southern Italy. Journal of Cleaner Production, 23, 37-46. 
Cardinael, R., Chevallier, T., Cambou, A., Béral, C., Barthès, B. G., Dupraz, C., \& Chenu, C. (2017). Increased soil organic carbon stocks under agroforestry: a survey of six different sites in France. Agriculture, Ecosystems \& Environment, 236, 243-255.

Carron, L. T. (1968). An outline of forest mensuration with special reference to Australia. Canberra: Australian National University Press.

CBS, PBL, RIVM, WUR (2019). Emissies broeikasgassen, 1990-2017 (indicator 0165, versie 34 , 25 januari 2019 ). www.clo.nl. Centraal Bureau voor de Statistiek (CBS), Den Haag; PBL Planbureau voor de Leefomgeving, Den Haag; RIVM Rijksinstituut voor Volksgezondheid en Milieu, Bilthoven; en Wageningen University and Research, Wageningen.

Centraal Bureau voor de Statistiek. (2010, 02 juli). Landbouw; gewassen, dieren, grondgebruik, bedrijfstype, 2000 - 2009 [Dataset]. Geraadpleegd van https://statline.cbs.nl/StatWeb/publication/?VW=T\&DM=SLNL\&PA=71465ned\&D1=214-229,286301\&D2 $=0 \& D 3=0,5,8-9 \& H D=091112-0914 \& H D R=G 2, G 1 \& S T B=T$

Centraal Bureau voor de Statistiek. (2017, 31 maart). Fruitteelt; oppervlakte fruitboomgaarden, soort fruit, 1992 - 2016 [Dataset]. Geraadpleegd van https://statline.cbs.nl/StatWeb/publication/?DM=SLNL\&PA=70671ned\&D1=a\&D2=a\&VW=T

Centraal Bureau voor de Statistiek. (2017, 31 maart). Emissies van broeikasgassen berekend volgens IPCC-voorschriften [Dataset]. Geraadpleegd van https://opendata.cbs.nl/statline/\#/CBS/nl/dataset/70946ned/table?dl=10757

Centraal Bureau voor de Statistiek. (2018, 20 november). Landbouw; gewassen, dieren, grondgebruik en arbeid op nationaal niveau [Dataset]. Geraadpleegd van

https://statline.cbs.nl/StatWeb/publication/?DM=SLNL\&PA=81302ned

Centraal Bureau voor de Statistiek. (2019, 25 januari). Fruitteelt; oppervlakte fruitboomgaarden, soort fruit [Dataset]. Geraadpleegd van

Chatterjee, N., Nair, P. R., Chakraborty, S., \& Nair, V. D. (2018). Changes in soil carbon stocks across the Forest-Agroforest-Agriculture/Pasture continuum in various agroecological regions: A metaanalysis. Agriculture, Ecosystems \& Environment, 266, 55-67.

Chave, J., Coomes, D., Jansen, S., Lewis, S. L., Swenson, N. G., \& Zanne, A. E. (2009). Towards a worldwide wood economics spectrum. Ecology letters, 12, 351-366.

Chifflot, V., Bertoni, G., Cabanettes, A., \& Gavaland, A. (2006). Beneficial effects of intercropping on the growth and nitrogen status of young wild cherry and hybrid walnut trees. Agroforestry systems, $66,13-21$.

Connell, J.H., Olson, W.H., Limberg, J. and Metcalf, S.G. (2010). Effects of various roots on 'Chandler' walnut catkin and pistillate bloom, tree growth, yield, and nut quality. Acta Hortic. 861, 237-244.

Crous-Duran, J., Graves, A. R., Garcia-de-Jalón, S., Paulo, J. A., Tomé, M., \& Palma, J. H. (2019). Assessing food sustainable intensification potential of agroforestry using a carbon balance method. iForest-Biogeosciences and Forestry, 12, 85.

Cutter, B. E., \& Garrett, H. E. (1993). Wood quality in alleycropped eastern black walnut. Agroforestry systems, 22, 25-32.

De Mol, R. M., \& Hilhorst, M. A. (2003). Methaan-, lachgas-en ammoniakemissies bij productie, opslag en transport van mest. IMAG. 
De Stefano, A., \& Jacobson, M. G. (2018). Soil carbon sequestration in agroforestry systems: a metaanalysis. Agroforestry Systems, 1-15.

Dijkstra, F. A., \& Cheng, W. (2007). Interactions between soil and tree roots accelerate long-term soil carbon decomposition. Ecology Letters, 10, 1046-1053.

Dixon, R. K., Winjum, J. K., Andrasko, K. J., Lee, J. J., \& Schroeder, P. E. (1994). Integrated land-use systems: assessment of promising agroforest and alternative land-use practices to enhance carbon conservation and sequestration. Climatic change, 27, 71-92.

Ellena, M. et al. (2012). Advantages of high density planting of hazelnut orchards in South Chili: preliminary data. VIII International Congress on Hazelnut 1052.

Ellert, B. H., \& Bettany, J. R. (1995). Calculation of organic matter and nutrients stored in soils under contrasting management regimes. Canadian Journal of Soil Science, 75, 529-538.

Fontaine, S., Barot, S., Barré, P., Bdioui, N., Mary, B., \& Rumpel, C. (2007). Stability of organic carbon in deep soil layers controlled by fresh carbon supply. Nature, 450, 277.

Franco, S., \& Pancino, B. (2008, June). Economic result of organic hazelnut cultivation in the Monti Cimini area. In VII International Congress on Hazelnut 845 (pp. 783-788).

Ghaley, B. B., \& Porter, J. R. (2014). Determination of biomass accumulation in mixed belts of Salix, Corylus and Alnus species in combined food and energy production system. Biomass and Bioenergy, $63,86-91$.

Grant, J.A. and McGranahan, G.H. (2005). Orchard performance of 'Chandler' walnut on selected Juglans regia seedling rootstocks. Acta Hortic. 705, 365-370.

Germain, E. (1986). Bulletin Technique et d'Information. 414-415: 933-940.

Germain, E. and J. Sarraquigne (1966). Hazelnut training systems: comparison between three systems on three varieties. IV International Symposium on Hazelnut 445.

Heijerman-Peppelman, G., P.F.M.M. Roelofs (2010). Kwantitatieve Informatie Fruitteelt 2009/2010. Praktijkonderzoek Plant \& Omgeving. Rapportnr. 2009-41.

Heineke, B. (2010). Een gezonde bodem ligt in eigen handen. http://edepot.wur.nl/175941

Hergoualc'h, K., Blanchart, E., Skiba, U., Hénault, C., \& Harmand, J. M. (2012). Changes in carbon stock and greenhouse gas balance in a coffee (Coffea arabica) monoculture versus an agroforestry system with Inga densiflora, in Costa Rica. Agriculture, Ecosystems \& Environment, 148, 102-110.

Hoffman, M. (2018). Het fruitgewassen overzicht van in de Nederland geregistreerde en/of kwekersrecht verleende rassen. https://www.raadvoorplantenrassen. $\mathrm{nl} / \mathrm{nl} /$ kwekersrecht-entoelating/fruitgewassen/rassenregister-fruitgewassen/

Kengetallen organische stof [online]. Hankboek bodembemesting.

https://www.handboekbodemenbemesting. $\mathrm{nl} / \mathrm{nl} /$ handboekbodemenbemesting/Handeling/Organischestofbeheer/Organische-stof/Kengetallen-organische-stof.htm [gelezen op 24-02-2019]

Ontwerp van het Klimaatakkoord [online]. 21 december 2018. Klimaatakkoord. https://www.rijksoverheid.nl/documenten/rapporten/2018/12/21/ontwerp-klimaatakkoord [gelezen op 24-02-19] 
IPCC (1996) Revised. IPCC guidelines for National Greenhouse Gas Inventories, Volume 3.

Greenhouse gas inventory reference manual. Houghton, J.T.; Filho, L.G.M.; Lim, B.; Treanton, K.;

Mamaty, I.; Bonduki, Y.; Griggs, D.J.; Callender, B.A. (eds.). UK Meteorological Office, Bracknell, UK.

Jacobs, D. F., Selig, M. F., \& Severeid, L. R. (2009). Aboveground carbon biomass of plantation-grown American chestnut (Castanea dentata) in absence of blight. Forest Ecology and Management, 258, 288-294.

Jandl, R., Lindner, M., Vesterdal, L., Bauwens, B., Baritz, R., Hagedorn, F., ... \& Byrne, K. A. (2007). How strongly can forest management influence soil carbon sequestration?. Geoderma, 137, 253-268.

Jasprina Kremers ${ }^{1}$ Jenkins, J.C., Chojnacky, D.C., Heath, L.S., Birdsay, S.A. (2004). Comprehensive Database of Diameter-based Biomass Regressions for North American Tree Species. USDA Forest Service. Newton Square.

Jose, S. (2009). Agroforestry for ecosystem services and environmental benefits: an overview. Agroforestry systems, 76, 1-10.

Julian, J., Seavert, C., \& Olsen, J. L. (2008). An economic evaluation of the impact of eastern filbert blight resistant hazelnut cultivars in Oregon, USA. In VII International Congress on Hazelnut 845 (pp. 725-732).

Kell, D. B. (2012). Large-scale sequestration of atmospheric carbon via plant roots in natural and agricultural ecosystems: why and how. Phil. Trans. R. Soc. B, 367, 1589-1597

Kempler, C. et al. (1992), The effects of pruning and tree density on leaf physiology and yield of hazelnut. III International Symposium on Hazelnut 351.

Ketterings, Q. M., Coe, R., van Noordwijk, M., \& Palm, C. A. (2001). Reducing uncertainty in the use of allometric biomass equations for predicting above-ground tree biomass in mixed secondary forests. Forest Ecology and management, 146(1-3), 199-209.

Korac, M., Cerovic, S., Gološin, B., Ognjanov, V. and Miletic, R. (1993). Prospective Yugoslav walnut selections with lateral fruit buds. Acta Hortic. 311, 41-45.

Kutsch, W. L., Aubinet, M., Buchmann, N., Smith, P., Osborne, B., Eugster, W., ... \& Ceschia, E. (2010). The net biome production of full crop rotations in Europe. Agriculture, ecosystems \& environment, 139 , 336-345.

Kroodsma, D. A., \& Field, C. B. (2006). Carbon sequestration in California agriculture, 1980-2000. Ecological Applications, 16, 1975-1985.

Lal, R. (2004). Soil carbon sequestration impacts on global climate change and food security. science, 304, 1623-1627.

Lamlom, S. H., \& Savidge, R. A. (2003). A reassessment of carbon content in wood: variation within and between 41 North American species. Biomass and Bioenergy, 25, 381-388.

Larjavaara, M., \& Muller-Landau, H. C. (2013). Measuring tree height: a quantitative comparison of two common field methods in a moist tropical forest. Methods in Ecology and Evolution, 4, 793-801.

Lee, H. C., McCarl, B. A., Schneider, U. A., \& Chen, C. C. (2007). Leakage and comparative advantage implications of agricultural participation in greenhouse gas emission mitigation. Mitigation and Adaptation Strategies for Global Change, 12, 471-494.

Lemus, G. (2009). Innovative methods of walnut production in South America. VI International Walnut Symposium 861 . 
Leslie, C.A. and McGranahan, G.H. (2014). The California walnut improvement program: scion breeding and rootstock development. Acta Hortic. 1050, 81-88.

Lesschen, J. P., Heesmans, H. I. M., Mol-Dijkstra, J. P., van Doorn, A. M., Verkaik, E., van den Wyngaert, I. J. J., \& Kuikman, P. J. (2012). Mogelijkheden voor koolstofvastlegging in de Nederlandse landbouw en natuur (No. 2396). Alterra.

Levia Jr, D. F. (2008). A generalized allometric equation to predict foliar dry weight on the basis of trunk diameter for eastern white pine (Pinus strobus L.). Forest ecology and management, 255, 17891792.

Lorenz, K., \& Lal, R. (2014). Soil organic carbon sequestration in agroforestry systems. A review. Agronomy for Sustainable Development, 34, 443-454. .

Lu, S., Meng, P., Zhang, J., Yin, C., \& Sun, S. (2015). Changes in soil organic carbon and total nitrogen in croplands converted to walnut-based agroforestry systems and orchards in southeastern Loess Plateau of China. Environmental monitoring and assessment, 187, 688.

Marvinney, E., Kendall, A., \& Brodt, S. (2014). A comparative assessment of greenhouse gas emissions in California almond, pistachio, and walnut production. In Proceedings of the 9th International Conference LCA of Food San Francisco, San Francisco, CA, USA (pp. 8-10).

Me, G. et al. (2000). Comparison of two training systems in hazelnut. V International Congress on Hazelnut 556.

Nair P.K.R., Gordon A., Mosquera-Losada M.R. (2008) Agroforestry. Encyclopaedia Ecology 1:1010110

Nair, P. K. R. (2012). Carbon sequestration studies in agroforestry systems: a reality-check. Agroforestry Systems, 86, 243-253.

Negash, M., \& Kanninen, M. (2015). Modeling biomass and soil carbon sequestration of indigenous agroforestry systems using CO2FIX approach. Agriculture, Ecosystems \& Environment, 203, 147-155.

Nelissen, V., Coussement, Tom., Pardon, P., Reubens, Bert. (2018). Effect van agroforestry op organische stof en nutriënten. Agroforestry Vlaanderen.

Ninot, A., Rovira, M. and Aletà, N. (2005). Mechanical pruning in walnut hedgerow orchard. Acta Hortic. 705, 559-562.

Oelbermann, M., Voroney, R. P., \& Gordon, A. M. (2004). Carbon sequestration in tropical and temperate agroforestry systems: a review with examples from Costa Rica and southern Canada. Agriculture, Ecosystems \& Environment, 104, 359-377.

Ohmann, L. F., Grigal, D. F., \& Brander, R. B. (1976). Biomass estimation for five shrubs from northeastern Minnesota. Research Paper NC-133. St. Paul, MN: US Dept. of Agriculture, Forest Service, North Central Forest Experiment Station, 133.

Olsen, J.L. (2013). Growing hazelnuts in the Pacific Northwest: Orchard design

Olson, W.H., Lampinen, B., Metcalf, S., Micke, W. and Ramos, D.E. (2005). Walnut training and hedging for early production and profit - Final Report. Acta Hortic. 705, 487-492.

Oosterbaan, A. (2015). Walnoot+: een boom voor iedereen. 88 pagina's.

Oosterbaan, A., \& Kuiters, A. T. (2009). Agroforestry in the Netherlands. In Agroforestry in Europe (pp. 331-341). Springer, Dordrecht. 
Oosterbaan, A., \& Schepers, H. (2005). Mogelijkheden voor notenteelt met tussengewas. De Fruitteelt, 95, 16-17.

Palma, J. H. (2017a). CliPick-Climate change web picker. A tool bridging daily climate needs in process based modelling in forestry and agriculture. Forest systems, 26, 14.

Palma, J. H., Oliveira, T., Crous-Duran, J., Graves, A. R., Garcia de Jalon, S., Upson, M., ... \& Mosquera-Losada, M. R. (2017b). Modelled agroforestry outputs at field and farm scale to support biophysical and environmental assessments.

Palma, J. H., Crous-Durán, J., Graves, A. R., de Jalon, S. G., Upson, M., Oliveira, T. S., ... \& Burgess, P. J. (2018). Integrating belowground carbon dynamics into Yield-SAFE, a parameter sparse agroforestry model. Agroforestry systems, 92, 1047-1057.

Panwar, P., Chauhan, S., Kaushal, R., Das, D. K., AroraR, G., Chaturvedi, O. P. \& Tewari, S. (2017). Carbon sequestration potential of poplar-based agroforestry using the CO2FIX model in the IndoGangetic Region of India. Tropical Ecology, 58(2).

Polito, V.S., Pinney, K., Weinbaum, S., Aradhya, M.K., Dangl, J., Vaknin, Y. and J.A. Grant (2006). Walnut pollination dynamics: pollen flow in walnut orchards. Acta Hortic. 705: 465-472.

Postma M. (2005) It's all in the mix. Dissertation, Wageningen University

Ramos D. et al. (1995). Hedgerow versus standard high density management systems for walnuts. III International Walnut Congress 442.

Ramos, D.E., Olson, W.H., Osgood, J.W., Krueger, W.H. and Snyder, R.G. (1992). Annual and biennial mechanical pruning of hedgerow English walnuts. Acta Hortic. 322, 135-140.

Rawls, W. J., Pachepsky, Y. A., Ritchie, J. C., Sobecki, T. M., \& Bloodworth, H. (2003). Effect of soil organic carbon on soil water retention. Geoderma, 116, 61-76.

Ramos D. et al. (2001). Establishment and management considerations for walnut hedgerows orchards. IV International Walnut Symposium.

Reubens, B., D'Haene, K., D'hose, T. \& Ruysschaert, G. (2010). Bodemkwaliteit en landbouw: een literatuurstudie. Bodembreed Interreg, ILVO Merelbeke-Lembergen, België.

Rizvi, R. H., Newaj, R., Chaturvedi, O. P., Prasad, R., Alam, B., Handa, A. K. \& Chaturvedi, M. (2017). Mitigating climate vagaries through adoption of agroforestry land use in Maharashtra, India.

Rouskas, D. and Zakynthinos, G. (2001). Preliminary evaluation of seventy walnut (Juglans regia L.) seedlings selections in Greece. Acta Hortic. 544, 61-72.

Rutter, P. and M. Shepard (2002). Hybrid hazelnut handbook.

Santos, A., \& Silva, A. P. (2000). Hazelnut productivity in northern Portugal. In V International Congress on Hazelnut 556 (pp. 97-102).

Sarraquigne, J. (2004). Hazelnut production in France. VI International Congress on Hazelnut 686.

Schelhaas, M. J., van Esch, P. W., Groen, T. A., de Jong, B. H. J., Kanninen, M., Liski, J. \& Pedroni, L. (2004). CO2FIX V 3.1-Manual. Alterra, Wageningen.

Schelhaas, M. J., Van Esch, P. W., Groen, T. A., De Jong, B. H. J., Kanninen, M., Liski, J., ... \& Pedroni, L. (2004). CO2FIX V 3.1 A modelling framework for quantifying carbon sequestration in forest ecosystems (No. 1068). Alterra-Centrum Ecosystemen. 
Schroth, G., D'Angelo, S. A., Teixeira, W. G., Haag, D., \& Lieberei, R. (2002). Conversion of secondary forest into agroforestry and monoculture plantations in Amazonia: consequences for biomass, litter and soil carbon stocks after 7 years. Forest Ecology and Management, 163, 131-150.

Schütt, P., Schuck, H.J., Aas, G. and Lang, U.A. (1994). Enzyklopdie der Holzgewchse. Handbuch und Atlas der Dendrologie. Ecomed, Landsberg am Lech, Germany, ISBN 3-609-72030-1.

Smith, J., Pearce, B. D., \& Wolfe, M. S. (2013). Reconciling productivity with protection of the environment: Is temperate agroforestry the answer?. Renewable Agriculture and Food Systems, 28, 80-92.

SOMO (2010). Quick Scan Hazelnootsector; Onderzoek naar de hazelnootsector met focus op de Nederlandse verwerkers.

Soto-Pinto, L., Anzueto, M., Mendoza, J., Ferrer, G. J., \& de Jong, B. (2010). Carbon sequestration through agroforestry in indigenous communities of Chiapas, Mexico. Agroforestry Systems, 78, 39.

Stavi, I., \& Lal, R. (2013). Agriculture and greenhouse gases, a common tragedy. A review. Agronomy for sustainable development, 33, 275-289.

De Stefano, A., \& Jacobson, M. G. (2018). Soil carbon sequestration in agroforestry systems: a metaanalysis. Agroforestry systems, 1-15.

Stockmann, U., Adams, M. A., Crawford, J. W., Field, D. J., Henakaarchchi, N., Jenkins, M., ... \& Wheeler, I. (2013). The knowns, known unknowns and unknowns of sequestration of soil organic carbon. Agriculture, Ecosystems \& Environment, 164, 80-99.

Szott, L. T., \& Kass, D. C. L. (1993). Fertilizers in agroforestry systems. Agroforestry Systems, 23, 157-176.

Tanrivermiş, H. (2008). Comparative economic assessment of conventional and organic hazelnut farming in turkey: Results of questionnaires from three years. Biological agriculture \& horticulture, 26, 235-267.

Torralba, M., Fagerholm, N., Burgess, P. J., Moreno, G., \& Plieninger, T. (2016). Do European agroforestry systems enhance biodiversity and ecosystem services? A meta-analysis. Agriculture, ecosystems \& environment, 230, 150-161.

Tous, J. (2004). Hazelnut production Spain. VI International Congress on Hazelnut 686.

Tous, J. et al. (1992). Cultural practices in hazelnut production. III International Congress on Hazelnut 351.

Vahdati, K., Hassani, D. and Rezaee, R. (2014). Behavior of some early mature and dwarf Persian walnut trees in Iran. Acta Hortic. 1050, 189-196.

Vahdati, K., Sarikhani Khorami, S. and Arab, M.M. (2018). Walnut: a potential multipurpose nut crop for reclaiming deteriorated lands and environment. Acta Hortic. 1190, 95-100.

van Bruggen, C., Bannink, A., Groenestein, C. M., de Haan, B. J., Huijsmans, J. F. M., Luesink, H. H., \& Vonk, J. (2014). Emissies naar lucht uit de landbouw in 2012: berekeningen van ammoniak, stikstofoxide, lachgas, methaan en fijn stof met het model NEMA (No. 3). Wettelijke Onderzoekstaken Natuur \& Milieu.

van der Werf, W., Keesman, K., Burgess, P. et al. (2007) Yield-SAFE: a parameter-sparse, processbased dynamic model for predicting resource capture, growth, and production in agroforestry systems. Ecol Eng 29:419-433. 
Veen, E. M. Vijn, M. Elings (2011). Multifunctionele landbouw in Nederland. Meer dan boeren alleen. Roodbont, Taskforce Multifunctionele landbouw \& Wageningen UR.

Veltkamp H.J. \& H. Blumink (2004). Actual situation and prospects of walnut production in The Netherlands. Bijdrage 5e International Walnut symposium, nov. 2004 Sorrento (Italië)

Vijn, M, F. van Alebeek, M. van der Voort, M. van Boxtel, M. Schoutsen (2014). De verkoop van vlees van eigen dieren. Wageningen University \& Research. PPO nr. 611.

Visser de,J. M. Meyer, L. Zampieri, L.Manda, I. Hoendervangers and E. Sweep (2016). Suitability of nuts cultivation of in the Netherlands. Student report ACT-1586.

Vleeshouwers, L. M., \& Verhagen, A. (2002). Carbon emission and sequestration by agricultural land use: a model study for Europe. Global change biology, 8, 519-530.

Wang, G.A., Zhang, Q., Huang, M.M. and Yakup, A. (2014a). The breeding of six Xinjiang dwarf walnut cultivars. Acta Hortic. 1050, 151-159.

Wang, G., Wang, J.Y., He, Q., Wu, J. and Zhang, C.H. (2014b). Agronomic evaluation and heritability of JIN RS-2 and JIN RS-3 walnut rootstocks. Acta Hortic. 1050, 113-121.

Wauters, J. B., Coudert, S., Grallien, E., Jonard, M., \& Ponette, Q. (2008). Carbon stock in rubber tree plantations in Western Ghana and Mato Grosso (Brazil). Forest Ecology and Management, 255, 23472361.

Wertheim S.J. (1981). De teelt van walnoten. Consulentschap in Algemene Dienst voor de Fruitteelt in de volle grond. Proefstation voor fruitteelt, Wilhelminadorp.

Wertheim S.J. (1995). Walnut cultivar evaluation in the Netherlands. III International Walnut Congress 442 .

Wertheim S.J. and J. Goedegebure (1988). De teelt van hazelnoten. Consulentschap in Algemene Dienst voor de Fruitteelt in de volle grond. Proefstation voor fruitteelt, Wilhelminadorp.

Yadav, R. and N.N. Chandra (2015). Micropropagation of walnut (Juglans regia L.) trees. Annals of Horticulture 8: 16-21.

Zhang, H., Wang, K., Zeng, Z., Du, H., \& Zeng, F. (2017). Biomass and Carbon Sequestration by Juglans regia Plantations in the Karst Regions of Southwest China. Forests, 8, 103.

Zianis, D., Muukkonen, P., Mäkipää, R., \& Mencuccini, M. (2005). Biomass and stem volume equations for tree species in Europe. FI.

\section{Websites}

https://www.nieuweoogst.nu/nieuws/2018/07/25/een-prima-milieuvriendelijke-neventak https://slowfood.nl/utrecht/de-wondere-wereld-van-de-walnoot/

https://www.mobipers.nl/

https://www.cbs.nl/nl-nl/nieuws/2018/33/wijnbouw-in-nederland-licht-gestegen https://www.cbs.nl/nl-nl/nieuws/2018/51/wijnboeren-leveren-vaakst-direct-aan-consument https://boerderijijs.com/ 


\section{Bijlage 1 Lijst aangeboden walnootrassen in Nederland (niet uitputtend)}

\begin{tabular}{|c|}
\hline CULTIVAR \\
\hline 8 Minunat \\
\hline Adams 10 \\
\hline Adams-10 \\
\hline Afsnee \\
\hline Alhed \\
\hline Amanda \\
\hline Amphyon \\
\hline Ampyon \\
\hline Apollo \\
\hline Aufhanser Baden \\
\hline Aufhauser \\
\hline Aufhauser Baden \\
\hline Axel \\
\hline Axel \\
\hline Axel \\
\hline Axel \\
\hline Badka Makhno \\
\hline Bella \\
\hline Bella Maria \\
\hline Bella Maria \\
\hline Big and easy \\
\hline Big and easy \\
\hline Bijou \\
\hline Bijou \\
\hline Blanco \\
\hline Bolle Jan \\
\hline Bright \\
\hline Broadview \\
\hline Broadview \\
\hline Broadview \\
\hline Buccaneer \\
\hline Buccaneer \\
\hline Buccaneer \\
\hline Buzsáki \\
\hline Buzsaki Pirosbelu \\
\hline Buzsaki Pirosbelu \\
\hline Carpathian \\
\hline Cazacu \\
\hline Chander \\
\hline Chandler \\
\hline Chiara \\
\hline Chiara \\
\hline Chiara \\
\hline
\end{tabular}

\section{CONTACT}

http://www.herenland.nl/

Smallekamp

De Acht Plagen

Boomkwekerij de Bock

op termijn beschikbaar De Acht Plagen

op termijn beschikbaar De Acht Plagen

De Acht Plagen

Smallekamp

http://www.boomkwekerij-frijns.nl

http://www.herenland.nl/

De Acht Plagen

Smallekamp

http://www.herenland.nl/

De Bruyn BVBA

Smallekamp

De Acht Plagen

op termijn beschikbaar De Acht Plagen

De Acht Plagen

http://www.fruitbomen.net/walnoot/

http://www.herenland.nl/

Smallekamp

De Acht Plagen

Boomkwekerij de Bock

De Acht Plagen

De Acht Plagen

Smallekamp

De Acht Plagen

https://www.tenhoven-bomen.nl/fruitbomen

Smallekamp

De Acht Plagen

https://www.tenhoven-bomen.nl/fruitbomen

Smallekamp

De Acht Plagen

De Acht Plagen

Smallekamp

Smallekamp

plantfinder, geen teler bekend

http://www.herenland.nl/

http://www.herenland.nl/

op termijn beschikbaar De Acht Plagen

http://www.herenland.nl/

Smallekamp

De Acht Plagen
PRODUCTIELAND

Nederland

Nederland

Nederland

Nederland

Nederland

Nederland

Nederland

Nederland

Nederland

Nederland

Nederland

Nederland

Nederland

Nederland

Nederland

Nederland

Nederland

Nederland

Nederland

Nederland

Nederland

Nederland

Nederland

Nederland

Nederland

Nederland

Nederland

Nederland

Nederland

Nederland

Nederland

Nederland

Nederland

Nederland

Nederland

Nederland

Nederland

Nederland

Nederland

Nederland

Nederland

Nederland 


\begin{tabular}{|c|c|c|}
\hline Chisiniovschii & http://www.herenland.nl/ & Nederland \\
\hline Codrene & http://www.herenland.nl/ & Nederland \\
\hline Coenen & http://www.fruitbomen.net/walnoot/ & Nederland \\
\hline Coenen & Smallekamp & Nederland \\
\hline Coenen & De Acht Plagen & Nederland \\
\hline Commandant & De Acht Plagen & Nederland \\
\hline Corne & plantfinder, geen teler bekend & \\
\hline Corne du Perigord & http://www.herenland.nl/ & Nederland \\
\hline Cyril & Smallekamp & Nederland \\
\hline Cyril & De Acht Plagen & Nederland \\
\hline Dionym & Boomkwekerij De Linde & Nederland \\
\hline Dionym & Smallekamp & Nederland \\
\hline Dionym & De Acht Plagen & Nederland \\
\hline Drjanovski & Smallekamp & Nederland \\
\hline Dwarf & De Acht Plagen & Nederland \\
\hline Dwarf & De Acht Plagen & Nederland \\
\hline Dwarf Karlik 3 & Smallekamp & Nederland \\
\hline Dwarf Karlik 5 & Smallekamp & Nederland \\
\hline Esterhazy 2 & Smallekamp & Nederland \\
\hline Esterhazy-2 & De Acht Plagen & Nederland \\
\hline Ferjean & plantfinder, geen teler bekend & \\
\hline Ferjean Imfel & plantfinder, geen teler bekend & \\
\hline Fernette & op termijn beschikbaar De Acht Plagen & Nederland \\
\hline Fernor & Boomkwekerij de Bock & Nederland \\
\hline Fernor & op termijn beschikbaar De Acht Plagen & Nederland \\
\hline Fey's Spezial & plantfinder, geen teler bekend & \\
\hline Finkenwerder & op termijn beschikbaar De Acht Plagen & Nederland \\
\hline Franquette & Boomkwekerij de Bock & Nederland \\
\hline Franquette & Smallekamp & Nederland \\
\hline Franquette & De Acht Plagen & Nederland \\
\hline Geoagiv & op termijn beschikbaar De Acht Plagen & Nederland \\
\hline Gilles & Smallekamp & Nederland \\
\hline Gilles & De Acht Plagen & Nederland \\
\hline Han Feng & Smallekamp & Nederland \\
\hline Hansen & http://www.fruitbomen.net/walnoot/ & Nederland \\
\hline Hansen & plantfinder, geen teler bekend & \\
\hline Hansen & Smallekamp & Nederland \\
\hline Haratun-2 & op termijn beschikbaar De Acht Plagen & Nederland \\
\hline Haratun-3 & op termijn beschikbaar De Acht Plagen & Nederland \\
\hline Harrison & plantfinder, geen teler bekend & \\
\hline HB51 & op termijn beschikbaar De Acht Plagen & Nederland \\
\hline Heterophylla & plantfinder, geen teler bekend & \\
\hline Hodonin & op termijn beschikbaar De Acht Plagen & Nederland \\
\hline Hospozin & op termijn beschikbaar De Acht Plagen & Nederland \\
\hline Hrusovany & op termijn beschikbaar De Acht Plagen & Nederland \\
\hline Jinboxiang-1 & De Acht Plagen & Nederland \\
\hline Jinboxiang-2 & op termijn beschikbaar De Acht Plagen & Nederland \\
\hline Jinboxiang-3 & op termijn beschikbaar De Acht Plagen & Nederland \\
\hline \multicolumn{3}{|l|}{ Juglans regia ' } \\
\hline Laciniata' & http://www.fruitbomen.net/walnoot/ & Nederland \\
\hline \multicolumn{3}{|l|}{ Juglans regia ' } \\
\hline Purpurea' & http://www.fruitbomen.net/walnoot/ & Nederland \\
\hline
\end{tabular}




\begin{tabular}{|c|c|c|}
\hline Jupanesti & op termijn beschikbaar De Acht Plagen & Nederland \\
\hline Jupiter & http://www.fruitbomen.net/walnoot/ & Nederland \\
\hline Jupiter & Smallekamp & Nederland \\
\hline Jupiter & De Acht Plagen & Nederland \\
\hline Kanonskogel & De Acht Plagen & Nederland \\
\hline Kaplan & De Acht Plagen & Nederland \\
\hline Kappels & De Acht Plagen & Nederland \\
\hline Kardinal & De Acht Plagen & Nederland \\
\hline Karmin & op termijn beschikbaar De Acht Plagen & Nederland \\
\hline Kempeneers & De Acht Plagen & Nederland \\
\hline Kirschnuss & Smallekamp & Nederland \\
\hline Kirschnuss & Smallekamp & Nederland \\
\hline Kwanten reuzennoot & Smallekamp & Nederland \\
\hline Lake & http://www.boomkwekerij-frijns.nl & Nederland \\
\hline Lange & De Acht Plagen & Nederland \\
\hline Lange & De Acht Plagen & Nederland \\
\hline Lange van lod & Smallekamp & Nederland \\
\hline Lara & plantfinder, geen teler bekend & \\
\hline Lara Pieral & op termijn beschikbaar De Acht Plagen & Nederland \\
\hline Loiko-1 & op termijn beschikbaar De Acht Plagen & Nederland \\
\hline Loiko-6 & op termijn beschikbaar De Acht Plagen & Nederland \\
\hline Loiko-63 & op termijn beschikbaar De Acht Plagen & Nederland \\
\hline Louny & op termijn beschikbaar De Acht Plagen & Nederland \\
\hline Manitou & op termijn beschikbaar De Acht Plagen & Nederland \\
\hline Maras 12 & De Acht Plagen & Nederland \\
\hline Maras 18 & op termijn beschikbaar De Acht Plagen & Nederland \\
\hline Mare & http://www.fruitbomen.net/walnoot/ & Nederland \\
\hline Mars & Smallekamp & Nederland \\
\hline Mars & De Acht Plagen & Nederland \\
\hline Mayette & plantfinder, geen teler bekend & \\
\hline Mayette & op termijn beschikbaar De Acht Plagen & Nederland \\
\hline Meylanaise & op termijn beschikbaar De Acht Plagen & Nederland \\
\hline Meylannaise & plantfinder, geen teler bekend & \\
\hline Milotai-10 & De Acht Plagen & Nederland \\
\hline Milotia 10 & Smallekamp & Nederland \\
\hline Mini & De Acht Plagen & Nederland \\
\hline Mini & De Acht Plagen & Nederland \\
\hline Mini Multiflora nr 14 & Smallekamp & Nederland \\
\hline Monophylla & De Acht Plagen & Nederland \\
\hline No 16 & Boomkwekerij de Bock & Nederland \\
\hline No. 1247 Mehlen & Smallekamp & Nederland \\
\hline No. 16 & Smallekamp & Nederland \\
\hline No. 22 Kwanten & Smallekamp & Nederland \\
\hline No. 26 (Geisenheim- & & \\
\hline Rüdenheim) & Smallekamp & Nederland \\
\hline No. 26 Kwanten & Smallekamp & Nederland \\
\hline NorthDown & De Acht Plagen & Nederland \\
\hline Novaci & op termijn beschikbaar De Acht Plagen & Nederland \\
\hline Nr. 120 & Smallekamp & Nederland \\
\hline nr. 120 & De Acht Plagen & Nederland \\
\hline nr. 1247 & De Acht Plagen & Nederland \\
\hline nr. 139 & De Acht Plagen & Nederland \\
\hline
\end{tabular}




\begin{tabular}{|c|c|c|}
\hline Nr. 139 Weinheimer & Smallekamp & Nederland \\
\hline Nr. 16 & http://www.fruitbomen.net/walnoot/ & Nederland \\
\hline nr. 16 (=Rita?) & De Acht Plagen & Nederland \\
\hline nr. 22 & De Acht Plagen & Nederland \\
\hline nr. 26 & De Acht Plagen & Nederland \\
\hline nr. 90-024-03 & op termijn beschikbaar De Acht Plagen & Nederland \\
\hline nr. 91-075-08 & op termijn beschikbaar De Acht Plagen & Nederland \\
\hline nr. 91-084-02 & op termijn beschikbaar De Acht Plagen & Nederland \\
\hline nr. 95-014-03 & op termijn beschikbaar De Acht Plagen & Nederland \\
\hline nr.92-059-02 & op termijn beschikbaar De Acht Plagen & Nederland \\
\hline Olifantenoor & De Acht Plagen & Nederland \\
\hline Oostelaar & De Acht Plagen & Nederland \\
\hline Orang & De Acht Plagen & Nederland \\
\hline Parisienne & Boomkwekerij de Bock & Nederland \\
\hline Parisienne & Smallekamp & Nederland \\
\hline Pedro & Smallekamp & Nederland \\
\hline Pedro & De Acht Plagen & Nederland \\
\hline Pendula & De Acht Plagen & Nederland \\
\hline Pentatone & Smallekamp & Nederland \\
\hline Petra's Red Medac & Smallekamp & Nederland \\
\hline Petra's Red Medac & op termijn beschikbaar De Acht Plagen & Nederland \\
\hline Plovdivski & http://www.fruitbomen.net/walnoot/ & Nederland \\
\hline Plovdivski & Boomkekerij de Linde & Nederland \\
\hline Plovdivski & Smallekamp & Nederland \\
\hline Plovdivski & De Acht Plagen & Nederland \\
\hline Praepacturiens & plantfinder, geen teler bekend & \\
\hline Proslavski & plantfinder, geen teler bekend & \\
\hline Proslavski & Smallekamp & Nederland \\
\hline Proslavski & De Acht Plagen & Nederland \\
\hline Purpurea & De Acht Plagen & Nederland \\
\hline Purpurovy' $\odot$ & Smallekamp & Nederland \\
\hline Red & De Acht Plagen & Nederland \\
\hline Red & De Acht Plagen & Nederland \\
\hline Red Rief & Smallekamp & Nederland \\
\hline Red Seal & Smallekamp & Nederland \\
\hline Rita & http://www.fruitbomen.net/walnoot/ & Nederland \\
\hline Rita & Smallekamp & Nederland \\
\hline Rita & De Acht Plagen & Nederland \\
\hline Rode Donaunoot & Smallekamp & Nederland \\
\hline Rondede Montignac & op termijn beschikbaar De Acht Plagen & Nederland \\
\hline Rondo & De Acht Plagen & Nederland \\
\hline Rote & De Acht Plagen & Nederland \\
\hline Rote & De Acht Plagen & Nederland \\
\hline Rote & De Acht Plagen & Nederland \\
\hline Rote & De Acht Plagen & Nederland \\
\hline Rote Gubler & smallekamp & Nederland \\
\hline Rote Linzer & Smallekamp & Nederland \\
\hline Rote Linzer & Smallekamp & Nederland \\
\hline \multicolumn{3}{|l|}{ Rote moselwalnuss } \\
\hline G.509 & Smallekamp & Nederland \\
\hline Rote moselwulfnuss & Smallekamp & Nederland \\
\hline
\end{tabular}


Rote\# 139 (R.D. X nr.

139)

Smallekamp

Nederland

Roter Donaunuss

http://www.fruitbomen.net/walnoot/

Nederland

Rubis

De Acht Plagen

Nederland

Rubis (Noyer Rouge)

Smallekamp

Nederland

Rubra

Smallekamp

Rubra

De Acht Plagen

Nederland

Seifersdorfer

Smallekamp

Seifersdorfer Runde

http://www.fruitbomen.net/walnoot/

Nederland

Sibisel

De Acht Plagen

Nederland

Sibisel 8

Smallekamp

SK

De Acht Plagen

Soleze

plantfinder, geen teler bekend

Soleze

Smallekamp

Nederland

Nederland

Nederland

Nederland

Soléze

Sunland

De Acht Plagen

Nederland

Nederland

Smallekamp

Nederland

Sütyemez-1

op termijn beschikbaar De Acht Plagen

Nederland

Sychrov

De Acht Plagen

Nederland

Sychrov

De Acht Plagen

Nederland

Tehama

Smallekamp

Nederland

De Acht Plagen

Nederland

op termijn beschikbaar De Acht Plagen

Nederland

Urozhajnyi

Vysoke

Weinsberg

Weinsberg 1

op termijn beschikbaar De Acht Plagen

Nederland

De Acht Plagen

Nederland

Smallekamp

plantfinder, geen teler bekend

Weinsburg 1

De Acht Plagen

Nederland

Westenaar

De Acht Plagen

Nederland

Nederland

Wonder van Monrepos

Wratkop

Smallekamp

De Acht Plagen

Nederland

De Acht Plagen

Nederland

Nederland

http://www.fruitbomen.net/walnoot/ 


\section{Bijlage 2 Rassenlijst Walnoot (vanaf 1990, bijgewerkt december 2018)}

\begin{tabular}{|c|c|}
\hline Volgnummer & Juglans regia varieteit/cultivarnaam \\
\hline 1 & 15 Temmuz \\
\hline 2 & Adams 10 \\
\hline 3 & Ajiou \\
\hline 4 & Ak Terek \\
\hline 5 & Akça \\
\hline 6 & Akura \\
\hline 7 & Alazani \\
\hline 8 & ALM 7 \\
\hline 9 & Alsószentiváni 117 \\
\hline 10 & Amphyon \\
\hline 11 & Ampyon (schrijffout?) \\
\hline 12 & Anica \\
\hline 13 & Aragvi \\
\hline 14 & Ashley \\
\hline 15 & Atskuri \\
\hline 16 & Aufhauser Baden \\
\hline 17 & Avenisuri \\
\hline 18 & Avrora \\
\hline 19 & Axel \\
\hline 20 & B10 \\
\hline 21 & Bayrak \\
\hline 22 & Belbeksky 70 \\
\hline 23 & Bella Maria \\
\hline 24 & Big and Easy \\
\hline 25 & Bilecik \\
\hline 26 & Blackmer \\
\hline 27 & Blanco (= 26 Kwanten) \\
\hline 28 & Bolle Jan \\
\hline 29 & Bonifac \\
\hline 30 & Bright Pit \\
\hline 31 & Broadview \\
\hline 32 & Buccaneer \\
\hline 33 & Buzsáki Pirosbélü \\
\hline 34 & Calarasi \\
\hline 35 & Carpatica \\
\hline 36 & Chandler \\
\hline 37 & Chiara \\
\hline 38 & Chico \\
\hline 39 & Ciprian \\
\hline 40 & Cisco \\
\hline 41 & Claudia \\
\hline 42 & Coenen \\
\hline 43 & Concord \\
\hline 44 & Corne \\
\hline 45 & Cyril \\
\hline 46 & Daixiang \\
\hline 47 & Damavand \\
\hline
\end{tabular}




\begin{tabular}{|c|c|}
\hline 48 & Dionym \\
\hline 49 & Diriliş \\
\hline 50 & Drjanovski \\
\hline 51 & Drummond \\
\hline 52 & Durham \\
\hline 53 & Dwarf Karlik 3 \\
\hline 54 & Dwarf Karlik 5 \\
\hline 55 & EEF 6 \\
\hline 56 & Elit \\
\hline 57 & Esterhazy 2 \\
\hline 58 & Eureka \\
\hline 59 & Fenghui \\
\hline 60 & Feradam \\
\hline 61 & Ferbel \\
\hline 62 & Ferjean \\
\hline 63 & Fernette \\
\hline 64 & Fernor \\
\hline 65 & Ferouette \\
\hline 66 & Forde \\
\hline 67 & Franquette \\
\hline 68 & Germisara \\
\hline 69 & Gilles \\
\hline 70 & Gillet \\
\hline 71 & GOR 2 \\
\hline 72 & GOR 5 \\
\hline 73 & Grandjean \\
\hline 74 & Gustine \\
\hline 75 & $\mathrm{H} 1 / 1$ \\
\hline 76 & $\mathrm{H} 1 / 7$ \\
\hline 77 & $\mathrm{H} 2 / 1$ \\
\hline 78 & $\mathrm{H} 2 / 12$ \\
\hline 79 & Han Feng \\
\hline 80 & Hansen \\
\hline 81 & Hartley \\
\hline 82 & Howard \\
\hline 83 & Hybridiy \\
\hline 84 & Ideal \\
\hline 85 & Ivanhoe \\
\hline 86 & Ivarto \\
\hline 87 & Izvor 10 \\
\hline 88 & Jamal \\
\hline 89 & Jifeng \\
\hline 90 & Jinbofeng No.1 \\
\hline 91 & Jinboxiang 1 \\
\hline 92 & Jinboxiang 2 \\
\hline 93 & Jinboxiang 4 \\
\hline 94 & Jinboxiang 8 (serie walnoten) \\
\hline 95 & Jinlong 1 \\
\hline 96 & Jizaofeng \\
\hline 97 & JOP 2 \\
\hline 98 & Jupâneşti \\
\hline 99 & Jupiter \\
\hline 100 & Kaman 1 \\
\hline 101 & Kaspura \\
\hline 102 & Kirschnuss \\
\hline 103 & Krka \\
\hline
\end{tabular}




\begin{tabular}{|c|c|}
\hline 104 & Krnc \\
\hline 105 & Krymsky Urozhayany \\
\hline 106 & Kuixiang \\
\hline 107 & Kwanten nr. 22 \\
\hline 108 & Kwanten reuzennoot \\
\hline 109 & Kyrgyzskya Bomba \\
\hline 110 & Lange van Lod \\
\hline 111 & Lange van lod \\
\hline 112 & Lapin 1 \\
\hline 113 & Lapin 2 \\
\hline 114 & Lara \\
\hline 115 & Liaoning No. 1 \\
\hline 116 & Liaoning No. 10 \\
\hline 117 & Like-2 \\
\hline 118 & Longnan 15 \\
\hline 119 & Luguang \\
\hline 120 & Luguo \\
\hline 121 & Luguo 2 \\
\hline 122 & Luguo 7 \\
\hline 123 & Lvzao \\
\hline 124 & Malizia \\
\hline 125 & Maraş 12 \\
\hline 126 & Maras 18 \\
\hline 127 & Marbot \\
\hline 128 & Mars \\
\hline 129 & Mayette \\
\hline 130 & Metcalfe \\
\hline 131 & Meyric \\
\hline 132 & Midland \\
\hline 133 & Milotai 10 \\
\hline 134 & Milotai botermo \\
\hline 135 & Milotai intenziv \\
\hline 136 & Milotai kesei \\
\hline 137 & Milotia 10 \\
\hline 138 & Mini Multiflora nr 14 \\
\hline 139 & Miroslava \\
\hline 140 & MS15 \\
\hline 141 & MS17 \\
\hline 142 & MS19 \\
\hline 143 & MS20 \\
\hline 144 & MS23 \\
\hline 145 & MS26 \\
\hline 146 & MS27 \\
\hline 147 & MS29 \\
\hline 148 & Niksar 1 \\
\hline 149 & No. 1247 Mehlen \\
\hline 150 & No. 16 \\
\hline 151 & No. 22 Kwanten \\
\hline 152 & No. 26 (Geisenheim-Rüdenheim) \\
\hline 153 & No. 26 Kwanten \\
\hline 154 & Nr. 120 \\
\hline 155 & Nr. 1239 \\
\hline 156 & Nr. 1247 \\
\hline 157 & Nr. 139 Weinheimer \\
\hline 158 & Nr. 16 \\
\hline 159 & Nr. 16 \\
\hline
\end{tabular}




\begin{tabular}{|c|c|}
\hline 160 & Nr. 26 \\
\hline 161 & Nr. 509 \\
\hline 162 & Nugget \\
\hline 163 & Osh form \\
\hline 164 & Ovata \\
\hline 165 & Ovidiu \\
\hline 166 & Parisienne \\
\hline 167 & Payne \\
\hline 168 & Pedro \\
\hline 169 & Pentatone \\
\hline 170 & Pervomaysky \\
\hline 171 & Pescianski \\
\hline 172 & Pioner \\
\hline 173 & Placentia and Similar \\
\hline 174 & Proslavski \\
\hline 175 & Proslawski (schrijffout?) \\
\hline 176 & Purpurovy \\
\hline 177 & Pusa Khor \\
\hline 178 & Qingxiang* \\
\hline 179 & Qinquan 1 \\
\hline 180 & Red Rief \\
\hline 181 & $\operatorname{Rex}$ \\
\hline 182 & Ridi \\
\hline 183 & Rita \\
\hline 184 & Robert Livermore \\
\hline 185 & Rode Donau \\
\hline 186 & Rode Donaunoot \\
\hline 187 & Ronde de Montignac \\
\hline 188 & Rondo \\
\hline 189 & Ronutex \\
\hline 190 & Rote Linzer' (eind 2014 leverbaar als plantgoed) \\
\hline 191 & Rubra \\
\hline 192 & Saturn \\
\hline 193 & Sava \\
\hline 194 & Sebin \\
\hline 195 & Seifersdorfer \\
\hline 196 & Sen 2 \\
\hline 197 & Serr \\
\hline 198 & Sexton \\
\hline 199 & Shangsong 6 \\
\hline 200 & Shannon \\
\hline 201 & Sheal \\
\hline 202 & Sheynovo \\
\hline 203 & Sibişel 252 \\
\hline 204 & Sibişel 44 \\
\hline 205 & Sibisel 8 \\
\hline 206 & Solano \\
\hline 207 & Solèze \\
\hline 208 & Sorrento \\
\hline 209 & Sunland \\
\hline 210 & Şuşiţa \\
\hline 211 & Sütyemez 1 \\
\hline 212 & Sychrov \\
\hline 213 & Tehama \\
\hline 214 & Timval \\
\hline 215 & Tiszacsecsi 83 \\
\hline
\end{tabular}




\begin{tabular}{|c|c|}
\hline 216 & Trompito \\
\hline 217 & Tulare \\
\hline 218 & UC91-75-15 \\
\hline 219 & Uigursky \\
\hline 220 & Valcor \\
\hline 221 & Valcris \\
\hline 222 & Valmit (Verisval) \\
\hline 223 & Valrex \\
\hline 224 & Valstar \\
\hline 225 & Velniţa \\
\hline 226 & Vena \\
\hline 227 & VII/04 \\
\hline 228 & $\mathrm{VIII} / 91$ \\
\hline 229 & Vina \\
\hline 230 & Vynoslivy \\
\hline 231 & Waterloo \\
\hline 232 & Weinsberg 1 \\
\hline 233 & Wen 185 \\
\hline 234 & Westhofs Dwarf \\
\hline 235 & Wilsons Wonder \\
\hline 236 & Wunder von Monrepos \\
\hline 237 & $\mathrm{XI} / 01$ \\
\hline 238 & Xiangling \\
\hline 239 & Xinfeng \\
\hline 240 & Xinxin 2 \\
\hline 241 & $\mathrm{XIV} / 98$ \\
\hline 242 & XVIII/03 \\
\hline 243 & Yalova 1 \\
\hline 244 & Yalova 3 \\
\hline 245 & Yualin \\
\hline 246 & Yuanfeng \\
\hline 247 & Yunxin \\
\hline 248 & Yunxin 90306 \\
\hline 249 & Yunxin Gaoyuan \\
\hline 250 & Yunxin Yunalin \\
\hline 251 & Z-60 \\
\hline 252 & Z-62 \\
\hline 253 & Zanmei \\
\hline 254 & Zaoshuo \\
\hline 255 & Zha 343 \\
\hline 256 & Zhonghexiang \\
\hline 257 & Zhonglin 1 \\
\hline 258 & $\mathrm{ZP}-1,2,3,4,5$ \\
\hline
\end{tabular}




\section{Bijlage 3 Suggesties voor eerste aanplant onafhankelijke toetsing}

\begin{tabular}{|c|c|c|c|c|c|c|}
\hline Cultivar & Productie/boom & Bloeitijdstip & Lateraal dragend & Zoektegevoeligheid & Noot eigenschappen & Opmerkingen \\
\hline Bella Maria & ? & ? & ? & ? & $4.5 \times 5.5 \mathrm{~cm}$ & Ned. Kruising \\
\hline Cyril & $?$ & laat & $?$ & ? & groot, goed gevuld & Ned. Kruising (Groningen), gedeeltelijk zelfbestuivend \\
\hline Dwarf Karlik 3 & vroeg en hoog & $?$ & $?$ & $?$ & $?$ & herkomst Oekraine, dwergroei \\
\hline Dwarf Karlik 5 & vroeg en hoog & ? & ? & ? & ? & herkomst Oekraine, dwergroei \\
\hline Mars & ? & laat, zelf bestuivend & ? & zeer gezond & groot, goed smakend & herkomst Tjechie \\
\hline Milotia 10 & hoog & middentijds & $20-25 \%$ & ? & $\begin{array}{l}\text { 33-36mm kleur geelbruin, attactieve schaal, } \\
\text { kerninhoud 47-52\%, eenvoudig te breken }\end{array}$ & $533 \%$ vd takken dragend, vroegdragend \\
\hline No. 1247 Mehlen & ? & ? & ? & $?$ & ? & $?$ \\
\hline Purpurovy & $?$ & $?$ & $?$ & $?$ & $?$ & $?$ \\
\hline Red Rief & ? & $?$ & $?$ & $?$ & $?$ & $?$ \\
\hline Seifersdorfer & ? & ? & ? & ? & ? & ? \\
\hline Seifersdorfer Runde & ? & ? & $?$ & ? & ? & $?$ \\
\hline Soleze & ? & $?$ & $?$ & gemiddeld vabaar & ? & herkomst Frankrijk, goede kwaliteit \\
\hline Tehama & ? & ? & ? & ? & $?$ & $?$ \\
\hline Wonder von Monrepos & $\begin{array}{l}\text { hoog (mede door } \\
\text { apomictische } \\
\text { vruchtzetting) }\end{array}$ & laat (eind mei) & ? & ? & groot, glad, goed te kraken, 5 gram netto/noot & herkomst Geisenheim (D), gedeeltelijk \\
\hline
\end{tabular}




\section{Bijlage 4 Hazelnoot systeemgegevens}

\begin{tabular}{|c|c|c|c|c|c|c|c|c|c|}
\hline Land & Locatie & $\begin{array}{l}\text { Plantdichtheid } \\
\text { (m) }\end{array}$ & Bomen/ha & Variëteit & $\begin{array}{l}\text { Ouderdom (jaren } \\
\text { sinds geplant) }\end{array}$ & $\begin{array}{l}\text { Proef } \\
\text { jaaren }\end{array}$ & $\begin{array}{l}\text { Opbrengst } \\
\text { (ton/ha) }\end{array}$ & $\begin{array}{l}\text { Vers of } \\
\text { Gedroogd }\end{array}$ & Bron \\
\hline Canada & British colombia & $5.5 \times 3.7$ & 491 & Barcelona & 9 & 1991 & 1.33 & Niet vermeld & (Kempler, Todd Kabaluk et al. 1992) \\
\hline Canada & British colombia & $5.5 \times 3.7$ & 491 & Barcelona & 9 & 1991 & 1.09 & Niet vermeld & (Kempler, Todd Kabaluk et al. 1992) \\
\hline Canada & British colombia & $7.3 \times 5.5$ & 249 & Barcelona & 9 & 1991 & 0.83 & Niet vermeld & (Kempler, Todd Kabaluk et al. 1992) \\
\hline Canada & British colombia & $7.3 \times 5.5$ & 249 & Barcelona & 9 & 1991 & 0.73 & Niet vermeld & (Kempler, Todd Kabaluk et al. 1992) \\
\hline Frankrijk & Gironde & $5 \times 2.5$ & 800 & Ennis & Gemiddelde van $3-12$ & 1988-1995 & 2.10 & Niet vermeld & (Germain and Sarraquigne 1996) \\
\hline Frankrijk & Gironde & $5 \times 2$ & 1000 & Ennis & Gemiddelde van 3 - 12 & 1988-1995 & 2.07 & Niet vermeld & (Germain and Sarraquigne 1996) \\
\hline Frankrijk & Gironde & $5 \times 1.8$ (paar) & 1818 & Ennis & Gemiddelde van $3-12$ & 1988-1995 & 2.00 & Niet vermeld & (Germain and Sarraquigne 1996) \\
\hline Frankrijk & Gironde & $5 \times 3$ & 666 & Segorbe & Gemiddelde van 3 - 12 & $1988-1995$ & 1.60 & Niet vermeld & (Germain and Sarraquigne 1996) \\
\hline Frankrijk & Gironde & $5 \times 2.5$ & 800 & Segorbe & Gemiddelde van 3 - 12 & $1988-1995$ & 1.67 & Niet vermeld & (Germain and Sarraquigne 1996) \\
\hline Frankrijk & Gironde & $5 \times 2.3$ (paar) & 1480 & Segorbe & Gemiddelde van 3 - 12 & 1988-1995 & 1.88 & Niet vermeld & (Germain and Sarraquigne 1996) \\
\hline Frankrijk & Gironde & $5 \times 2.5$ & 800 & T Romana & Gemiddelde van 3 - 12 & $1988-1995$ & 1.31 & Niet vermeld & (Germain and Sarraquigne 1996) \\
\hline Frankrijk & Gironde & $5 \times 2$ & 1000 & T Romana & Gemiddelde van 3 - 12 & 1988-1995 & 1.27 & Niet vermeld & (Germain and Sarraquigne 1996) \\
\hline Frankrijk & Gironde & $5 \times 1.8$ (paar) & 1818 & T Romana & Gemiddelde van 3 - 12 & 1988-1995 & 1.42 & Niet vermeld & (Germain and Sarraquigne 1996) \\
\hline Italië & Cuneo, Piemonte & $5 \times 3$ & 666 & 101 & Gemiddelde van 7 - 11 & $1995-1999$ & 0.64 & Niet vermeld & (Me, Valentini et al. 2000) \\
\hline Italië & Cuneo, Piemonte & $5 \times 2.4$ (paar) & 1666 & 101 & Gemiddelde van 7 - 11 & 1995-1999 & 2.21 & Niet vermeld & (Me, Valentini et al. 2000) \\
\hline Italië & Cuneo, Piemonte & $5 \times 3$ & 666 & 119 & Gemiddelde van 7 - 11 & 1995-1999 & 1.38 & Niet vermeld & (Me, Valentini et al. 2000) \\
\hline Italië & Cuneo, Piemonte & $5 \times 2.4$ (paar) & 1666 & 119 & Gemiddlde van 7 - 11 & 1995-1999 & 1.86 & Niet vermeld & (Me, Valentini et al. 2000) \\
\hline Italië & Cuneo, Piemonte & $5 \times 3$ & 666 & $104 \mathrm{~F}$ & Gemiddelde van 7 - 11 & $1995-1999$ & 0.94 & Niet vermeld & (Me, Valentini et al. 2000) \\
\hline Italië & Cuneo, Piemonte & $5 \times 2.4$ (paar) & 1666 & $104 \mathrm{~F}$ & Gemiddelde van 7 - 11 & 1995-1999 & 1.02 & Niet vermeld & (Me, Valentini et al. 2000) \\
\hline Italië & Cuneo, Piemonte & $5 \times 3$ & 666 & $123 \mathrm{~F}$ & Gemiddelde van 7 - 11 & 1995-1999 & 1.09 & Niet vermeld & (Me, Valentini et al. 2000) \\
\hline Italië & Cuneo, Piemonte & $5 \times 2.4$ (paar) & 1666 & $123 \mathrm{~F}$ & Gemiddelde van 7 - 11 & 1995-1999 & 2.27 & Niet vermeld & (Me, Valentini et al. 2000) \\
\hline Italië & Cuneo, Piemonte & $5 \times 3$ & 666 & $3 \mathrm{~L}$ & Gemiddelde van $7-11$ & 1995-1999 & 0.80 & Niet vermeld & (Me, Valentini et al. 2000) \\
\hline
\end{tabular}




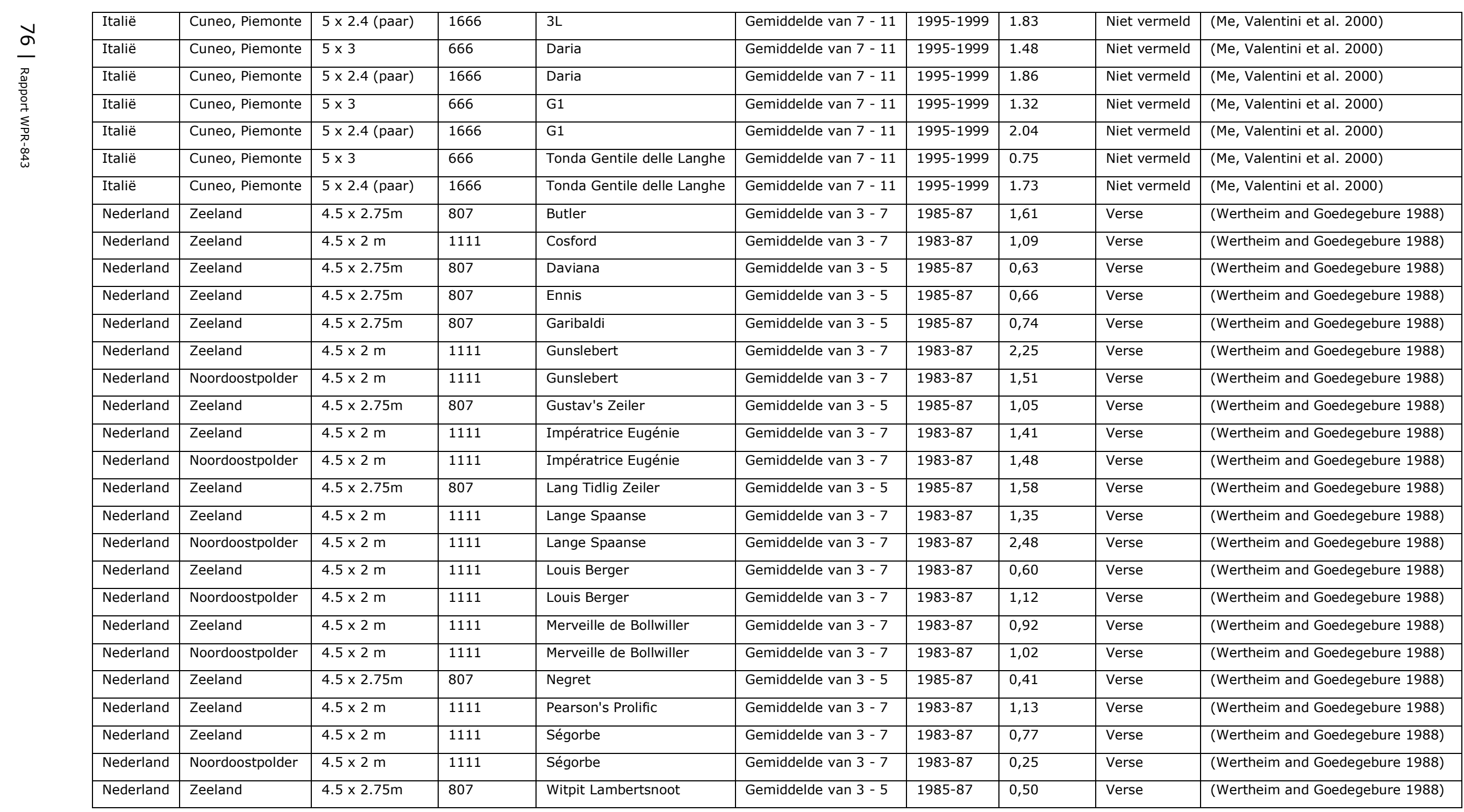




\section{Bijlage 5 Walnoot systeemgegevens}

\begin{tabular}{|c|c|c|c|c|c|c|c|c|c|c|}
\hline Land & Locatie & $\begin{array}{l}\text { Plantdichtheid } \\
\text { (m) }\end{array}$ & Trees/ha & Variëteit & $\begin{array}{l}\text { Ouderdom } \\
\text { (jaren sinds } \\
\text { geplant/ veld } \\
\text { geënt) }\end{array}$ & Proefjaren & Irrigation & $\begin{array}{l}\text { Opbrengst } \\
\text { (ton/ha) }\end{array}$ & $\begin{array}{l}\text { Vers of } \\
\text { Gedroogd }\end{array}$ & Bron \\
\hline Verenigde Staten & California & $7 \times 3.5$ & 407 & Howard & 5 & 1995 & Niet vermeld & 1.87 & Niet vermeld & (Ramos, Kelley et al. 2001) \\
\hline Verenigde Staten & California & $7 \times 3.5$ & 407 & Howard & 6 & 1996 & Niet vermeld & 4.659 & Niet vermeld & (Ramos, Kelley et al. 2001) \\
\hline Verenigde Staten & California & $7 \times 3.5$ & 407 & Howard & 7 & 1997 & Niet vermeld & 5.739 & Niet vermeld & (Ramos, Kelley et al. 2001) \\
\hline Verenigde Staten & California & $7 \times 3.5$ & 407 & Howard & 8 & 1998 & Niet vermeld & 2.961 & Niet vermeld & (Ramos, Kelley et al. 2001) \\
\hline Verenigde Staten & California & $7 \times 3.5$ & 407 & Howard & Gemiddelde 5-9 & 1995-1999 & Niet vermeld & 3.80725 & Niet vermeld & (Ramos, Kelley et al. 2001) \\
\hline Verenigde Staten & California & $7 \times 3.5$ & 407 & Howard & 5 & 1995 & Niet vermeld & 2.265 & Niet vermeld & (Ramos, Kelley et al. 2001) \\
\hline Verenigde Staten & California & $7 \times 3.5$ & 407 & Howard & 6 & 1996 & Niet vermeld & 4.752 & Niet vermeld & (Ramos, Kelley et al. 2001) \\
\hline Verenigde Staten & California & $7 \times 3.5$ & 407 & Howard & 7 & 1997 & Niet vermeld & 6.017 & Niet vermeld & (Ramos, Kelley et al. 2001) \\
\hline Verenigde Staten & California & $7 \times 3.5$ & 407 & Howard & 8 & 1998 & Niet vermeld & 3.375 & Niet vermeld & (Ramos, Kelley et al. 2001) \\
\hline Verenigde Staten & California & $7 \times 3.5$ & 407 & Howard & Gemiddelde 5-9 & 1995-1999 & Niet vermeld & 4.10225 & Niet vermeld & (Ramos, Kelley et al. 2001) \\
\hline Verenigde Staten & California & $7 \times 4.7$ & 306 & Howard & 5 & 1995 & Niet vermeld & 1.192 & Niet vermeld & (Ramos, Kelley et al. 2001) \\
\hline Verenigde Staten & California & $7 \times 4.7$ & 306 & Howard & 6 & 1996 & Niet vermeld & 3.312 & Niet vermeld & (Ramos, Kelley et al. 2001) \\
\hline Verenigde Staten & California & $7 \times 4.7$ & 306 & Howard & 7 & 1997 & Niet vermeld & 4.943 & Niet vermeld & (Ramos, Kelley et al. 2001) \\
\hline Verenigde Staten & California & $7 \times 4.7$ & 306 & Howard & 8 & 1998 & Niet vermeld & 2.541 & Niet vermeld & (Ramos, Kelley et al. 2001) \\
\hline Verenigde Staten & California & $7 \times 4.7$ & 306 & Howard & Gemiddelde 5-9 & 1995-1999 & Niet vermeld & 2.997 & Niet vermeld & (Ramos, Kelley et al. 2001) \\
\hline Verenigde Staten & California & $7 \times 4.7$ & 306 & Howard & 5 & 1995 & Niet vermeld & 1.879 & Niet vermeld & (Ramos, Kelley et al. 2001) \\
\hline Verenigde Staten & California & $7 \times 4.7$ & 306 & Howard & 6 & 1996 & Niet vermeld & 3.608 & Niet vermeld & (Ramos, Kelley et al. 2001) \\
\hline Verenigde Staten & California & $7 \times 4.7$ & 306 & Howard & 7 & 1997 & Niet vermeld & 5.021 & Niet vermeld & (Ramos, Kelley et al. 2001) \\
\hline Verenigde Staten & California & $7 \times 4.7$ & 306 & Howard & 8 & 1998 & Niet vermeld & 3.048 & Niet vermeld & (Ramos, Kelley et al. 2001) \\
\hline Verenigde Staten & California & $7 \times 4.7$ & 306 & Howard & Gemiddelde 5-9 & 1995-1999 & Niet vermeld & 3.389 & Niet vermeld & (Ramos, Kelley et al. 2001) \\
\hline
\end{tabular}




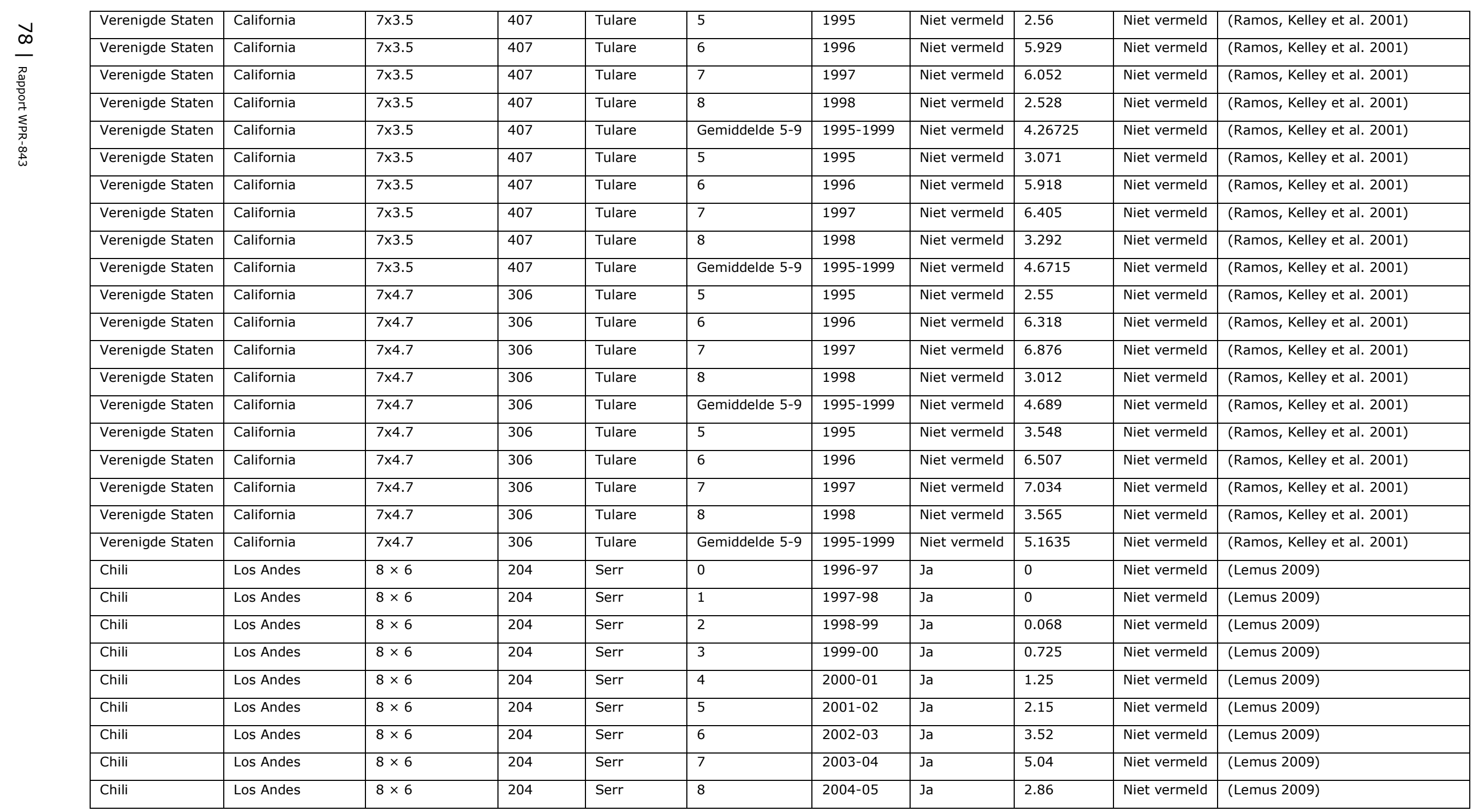




\begin{tabular}{|c|c|c|c|c|c|c|c|c|c|c|}
\hline Nederland & Wilhelminadorp & Niet vermeld & 125 & $\mathrm{Nr} 26$ & 12 & 1993 & Nee & 1.24 & Niet vermeld & (Wertheim 1995) \\
\hline Nederland & Wilhelminadorp & Niet vermeld & 125 & Nr 139 & 12 & 1993 & Nee & 0.97 & Niet vermeld & (Wertheim 1995) \\
\hline Nederland & Wilhelminadorp & Niet vermeld & 125 & Nr 1247 & 12 & 1993 & Nee & 1.19 & Niet vermeld & (Wertheim 1995) \\
\hline Nederland & Wilhelminadorp & Niet vermeld & 125 & Franquette & 12 & 1993 & Nee & 0.86 & Niet vermeld & (Wertheim 1995) \\
\hline Nederland & Wilhelminadorp & Niet vermeld & 125 & Broadview & 12 & 1993 & Nee & 2.23 & Niet vermeld & (Wertheim 1995) \\
\hline Nederland & Wilhelminadorp & Niet vermeld & 125 & Bucaneer & 12 & 1993 & Nee & 1.09 & Niet vermeld & (Wertheim 1995) \\
\hline Nederland & Wilhelminadorp & Niet vermeld & 125 & Parisienne & 12 & 1993 & Nee & 1.04 & Niet vermeld & (Wertheim 1995) \\
\hline Nederland & Wilhelminadorp & Niet vermeld & 125 & Soleze & 12 & 1993 & Nee & 1.4 & Niet vermeld & (Wertheim 1995) \\
\hline Nederland & Wilhelminadorp & Niet vermeld & 125 & Sunland & 12 & 1993 & Nee & 0.22 & Niet vermeld & (Wertheim 1995) \\
\hline Nederland & Wilhelminadorp & Niet vermeld & 125 & Lara & 12 & 1993 & Nee & 0.16 & Niet vermeld & (Wertheim 1995) \\
\hline Nederland & Wilhelminadorp & Niet vermeld & 125 & Adams 10 & 12 & 1993 & Nee & 0.38 & Niet vermeld & (Wertheim 1995) \\
\hline Nederland & Wilhelminadorp & Niet vermeld & 125 & Pedro & 12 & 1993 & Nee & 0.28 & Niet vermeld & (Wertheim 1995) \\
\hline Nederland & Wilhelminadorp & Niet vermeld & 125 & Tahama & 12 & 1993 & Nee & 0.77 & Niet vermeld & (Wertheim 1995) \\
\hline Nederland & Wilhelminadorp & Niet vermeld & 125 & $\mathrm{Nr} 26$ & 13 & 1994 & Nee & 0.75 & Niet vermeld & (Wertheim 1995) \\
\hline Nederland & Wilhelminadorp & Niet vermeld & 125 & $\mathrm{Nr} 139$ & 13 & 1994 & Nee & 1.69 & Niet vermeld & (Wertheim 1995) \\
\hline Nederland & Wilhelminadorp & Niet vermeld & 125 & $\mathrm{Nr} 1247$ & 13 & 1994 & Nee & 2.11 & Niet vermeld & (Wertheim 1995) \\
\hline Nederland & Wilhelminadorp & Niet vermeld & 125 & Franquette & 13 & 1994 & Nee & 0.53 & Niet vermeld & (Wertheim 1995) \\
\hline Nederland & Wilhelminadorp & Niet vermeld & 125 & Broadview & 13 & 1994 & Nee & 3.42 & Niet vermeld & (Wertheim 1995) \\
\hline Nederland & Wilhelminadorp & Niet vermeld & 125 & Bucaneer & 13 & 1994 & Nee & 1.22 & Niet vermeld & (Wertheim 1995) \\
\hline Nederland & Wilhelminadorp & Niet vermeld & 125 & Parisienne & 13 & 1994 & Nee & 1.73 & Niet vermeld & (Wertheim 1995) \\
\hline Nederland & Wilhelminadorp & Niet vermeld & 125 & Soleze & 13 & 1994 & Nee & 2.28 & Niet vermeld & (Wertheim 1995) \\
\hline Nederland & Wilhelminadorp & Niet vermeld & 125 & Sunland & 13 & 1994 & Nee & 0.48 & Niet vermeld & (Wertheim 1995) \\
\hline Nederland & Wilhelminadorp & Niet vermeld & 125 & Lara & 13 & 1994 & Nee & 0.3 & Niet vermeld & (Wertheim 1995) \\
\hline Nederland & Wilhelminadorp & Niet vermeld & 125 & Adams 10 & 13 & 1994 & Nee & 0.62 & Niet vermeld & (Wertheim 1995) \\
\hline Nederland & Wilhelminadorp & Niet vermeld & 125 & Pedro & 13 & 1994 & Nee & 1.6 & Niet vermeld & (Wertheim 1995) \\
\hline Nederland & Wilhelminadorp & Niet vermeld & 125 & Tahama & 13 & 1994 & Nee & 1.02 & Niet vermeld & (Wertheim 1995) \\
\hline
\end{tabular}




\section{Bijlage 6 Resultaten bodemanalyses referentiepercelen}

\section{Walnoot}

Bodemanalyses locatie Luttelgeest: Resultaten van 6 sub monsters en het gemiddelde $(0-30 \mathrm{~cm})$.

\begin{tabular}{llrrrrrrr}
\hline & & $\mathrm{a}$ & $\mathrm{b}$ & $\mathrm{c}$ & $\mathrm{d}$ & $\mathrm{e}$ & $\mathrm{f}$ & Average \\
\hline Klei & $\%$ & 3 & 2 & 2 & 1 & 1 & 1 & 2 \\
$\mathrm{pH}-\mathrm{KCL}$ & & 6.9 & 7.0 & 7.0 & 7.1 & 7.2 & 7.2 & 7.1 \\
$\mathrm{C}-\mathrm{org}$ & $\%$ & 2.1 & 1.9 & 2 & 1.3 & 1.5 & 1.3 & 1.7 \\
OS & $\%$ & 4.3 & 3.8 & 4 & 2.6 & 3 & 2.6 & 3.4 \\
C-tot & $\mathrm{g} \mathrm{C} / 100 \mathrm{~g}$ & 2.5 & 2.3 & 2.3 & 1.7 & 1.9 & 1.9 & 2.1 \\
$\mathrm{~N}$-tot & $\mathrm{mg} \mathrm{N} / \mathrm{kg}$ & 1990 & 1840 & 1900 & 1350 & 1600 & 1480 & 1693 \\
$\mathrm{C} / \mathrm{N}$ & & 12.6 & 12.5 & 12.1 & 12.6 & 11.9 & 12.8 & 12.4 \\
\hline
\end{tabular}

Bodemanalyses locatie Luttelgeest $(0-60 \mathrm{~cm})$ : Resultaten van 6 sub monsters en het gemiddelde $(0$ $-60 \mathrm{~cm})$.

\begin{tabular}{llrrrrrrr}
\hline & & $\mathrm{a}$ & $\mathrm{b}$ & $\mathrm{c}$ & $\mathrm{d}$ & $\mathrm{e}$ & \multicolumn{2}{c}{ Average } \\
\hline Klei & $\%$ & 1 & $<1$ & $<1$ & 2 & $<1$ & 1 & 1 \\
pH-KCL & & 7.6 & 7.6 & 7.7 & 7.6 & 7.6 & 7.5 & 7.6 \\
C-org & $\%$ & 0.5 & 0.3 & 0.3 & 0.4 & 0.4 & 0.4 & 0.4 \\
OS & $\%$ & 1.1 & 0.6 & 0.6 & 0.7 & 0.8 & 0.7 & 0.8 \\
C-tot & $\mathrm{g} \mathrm{C} / 100 \mathrm{~g}$ & 1.1 & 0.8 & 0.7 & 0.9 & 0.9 & 1.5 & 1.0 \\
N-tot & $\mathrm{mg} \mathrm{N} / \mathrm{kg}$ & 680 & 450 & 320 & 470 & 430 & 640 & 498 \\
C/N & & 16.2 & 17.8 & 21.9 & 19.1 & 20.9 & 23.4 & 19.9 \\
\hline
\end{tabular}

Bodemanalyses locatie Herveld: Resultaten van 6 sub monsters en het gemiddelde $(0-30 \mathrm{~cm})$.

\begin{tabular}{llrrrrrrr}
\hline & & $\mathrm{a}$ & $\mathrm{b}$ & $\mathrm{c}$ & $\mathrm{d}$ & $\mathrm{e}$ & $\mathrm{f}$ & Average \\
\hline Klei & $\%$ & 31 & 35 & 37 & 33 & 32 & 32 & 33 \\
$\mathrm{pH}-\mathrm{KCL}$ & & 6.4 & 6.3 & 6.4 & 6.5 & 6.6 & 6.5 & 6.5 \\
C-org & $\%$ & 8.2 & 2.9 & 2.4 & 2.6 & 3.1 & 2.8 & 3.7 \\
OS & $\%$ & 16.3 & 5.8 & 4.8 & 5.1 & 6.2 & 5.5 & 7.3 \\
C-tot & $\mathrm{g} \mathrm{C} / 100 \mathrm{~g}$ & 3.2 & 3.2 & 2.7 & 2.6 & 3.4 & 2.9 & 3.0 \\
N-tot & $\mathrm{mg} \mathrm{N} / \mathrm{kg}$ & 2660 & 2790 & 2460 & 2490 & 2930 & 2670 & 2667 \\
C/N & & 12.0 & 11.5 & 11.0 & 10.4 & 11.6 & 10.9 & 11.2 \\
\hline
\end{tabular}

Bodemanalyses locatie Herveld: Resultaten van 6 sub monsters en het gemiddelde $(0-60 \mathrm{~cm})$.

\begin{tabular}{llrrrrrrr}
\hline & & $\mathrm{a}$ & $\mathrm{b}$ & $\mathrm{c}$ & $\mathrm{d}$ & $\mathrm{e}$ & $\mathrm{f}$ & Average \\
\hline Klei & $\%$ & 38 & 41 & 38 & 36 & 37 & 36 & 38 \\
$\mathrm{pH}-\mathrm{KCL}$ & & 6.5 & 6.4 & 7.1 & 6.6 & 6.9 & 7.0 & 6.8 \\
C-org & $\%$ & 1.5 & 1.3 & 1.2 & 1.3 & 1.5 & 1.5 & 1.4 \\
OS & $\%$ & 3 & 2.7 & 2.5 & 2.6 & 3 & 3.1 & 2.8 \\
C-tot & $\mathrm{g} \mathrm{C} / 100 \mathrm{~g}$ & 1.8 & 1.3 & 1.4 & 1.3 & 1.5 & 1.7 & 1.5 \\
$\mathrm{~N}$-tot & $\mathrm{mg} \mathrm{N} / \mathrm{kg}$ & 1620 & 1450 & 1410 & 1490 & 1630 & 1690 & 1548 \\
$\mathrm{C} / \mathrm{N}$ & & 11.1 & 9.0 & 9.9 & 8.7 & 9.2 & 10.1 & 9.7 \\
\hline
\end{tabular}


Hazelnoot

Bodemanalyses locatie Breedenbroek: Resultaten van 6 sub monsters en het gemiddelde $(0-30 \mathrm{~cm})$.

\begin{tabular}{llrrrrrrr}
\hline & & $\mathrm{a}$ & $\mathrm{b}$ & $\mathrm{c}$ & $\mathrm{d}$ & $\mathrm{e}$ & \multicolumn{2}{c}{ Average } \\
\hline Klei & & 7 & 7 & 8 & 8 & 7 & 7 & 7 \\
$\mathrm{pH}-\mathrm{KCL}$ & & 5.8 & 5.0 & 5.8 & 5.5 & 5.6 & 5.0 & 5.5 \\
C-org & $\%$ & 1.5 & 1.5 & 1.7 & 1.5 & 1.5 & 1.3 & 1.5 \\
OS & $\%$ & 3.1 & 3 & 3.3 & 3.1 & 2.9 & 2.5 & 3.0 \\
C-tot & $\mathrm{g} \mathrm{C} / 100 \mathrm{~g}$ & 1.5 & 1.5 & 1.7 & 1.6 & 1.6 & 1.3 & 1.5 \\
$\mathrm{~N}$-tot & $\mathrm{mg} \mathrm{N} / \mathrm{kg}$ & 1330 & 1370 & 1550 & 1440 & 1460 & 1280 & 1405 \\
$\mathrm{C} / \mathrm{N}$ & & 11.3 & 10.9 & 11.0 & 11.1 & 11.0 & 10.2 & 10.9 \\
\hline
\end{tabular}

Bodemanalyses locatie Breedenbroek: Resultaten van 6 sub monsters en het gemiddelde $(0-60 \mathrm{~cm})$.

\begin{tabular}{llrrrrrrr}
\hline & & $\mathrm{a}$ & $\mathrm{b}$ & $\mathrm{c}$ & $\mathrm{d}$ & $\mathrm{e}$ & $\mathrm{f}$ & Average \\
\hline Klei & $\%$ & 9 & 8 & 9 & 8 & 9 & 9 & 9 \\
$\mathrm{pH}-\mathrm{KCL}$ & & 5.8 & 5.0 & 6.0 & 5.2 & 5.5 & 5.0 & 5.4 \\
C-org & $\%$ & 0.5 & 0.6 & 0.7 & 0.5 & 0.5 & 0.5 & 0.6 \\
OS & $\%$ & 1 & 1.2 & 1.3 & 1 & 1 & 0.9 & 1.1 \\
C-tot & $\mathrm{g} \mathrm{C} / 100 \mathrm{~g}$ & 0.5 & 0.6 & 0.6 & 0.6 & 0.5 & 0.5 & 0.6 \\
N-tot & $\mathrm{mg} \mathrm{N} / \mathrm{kg}$ & 460 & 580 & 570 & 550 & 510 & 520 & 532 \\
$\mathrm{C} / \mathrm{N}$ & & 10.9 & 10.3 & 10.5 & 10.9 & 9.8 & 9.6 & 10.3 \\
\hline
\end{tabular}

Bodemanalyses locatie Lelystad: Resultaten van 6 sub monsters en het gemiddelde $(0-30 \mathrm{~cm})$.

\begin{tabular}{llrrrrrrr}
\hline & & $\mathrm{a}$ & $\mathrm{b}$ & $\mathrm{c}$ & $\mathrm{d}$ & $\mathrm{e}$ & $\mathrm{f}$ & Average \\
\hline Klei & $\%$ & 7 & 7 & 7 & 8 & 8 & 7 & 7 \\
$\mathrm{pH}-\mathrm{KCL}$ & & 7.3 & 7.5 & 7.5 & 7.5 & 7.6 & 7.5 & 7.5 \\
C-org & $\%$ & 1.2 & 1.1 & 1.1 & 1.2 & 0.9 & 1.2 & 1.1 \\
OS & $\%$ & 2.5 & 2.2 & 2.2 & 2.4 & 1.8 & 2.3 & 2.2 \\
C-tot & $\mathrm{g} \mathrm{C} / 100 \mathrm{~g}$ & 1.8 & 1.8 & 1.8 & 1.8 & 1.6 & 1.7 & 1.8 \\
N-tot & $\mathrm{mg} \mathrm{N} / \mathrm{kg}$ & 1070 & 1000 & 1090 & 1020 & 860 & 1020 & 1010 \\
C/N & & 16.8 & 18.0 & 16.5 & 17.6 & 18.6 & 16.7 & 17.4 \\
C-anorg & $\%$ & 0.52 & 0.61 & 0.52 & 0.55 & 0.56 & 0.50 & 0.54 \\
Koolzure kalk & $\%$ & 3.7 & 4.4 & 3.7 & 3.9 & 4.0 & 3.5 & 3.9 \\
\hline
\end{tabular}

Bodemanalyses locatie Lelystad: Resultaten van 6 sub monsters en het gemiddelde $(0-60 \mathrm{~cm})$.

\begin{tabular}{llrrrrrrr}
\hline & & $\mathrm{a}$ & $\mathrm{b}$ & $\mathrm{c}$ & $\mathrm{d}$ & $\mathrm{e}$ & \multicolumn{1}{c}{ Average } \\
\hline Klei & $\%$ & 6 & 5 & 6 & 7 & 5 & 6 & 6 \\
$\mathrm{pH}-\mathrm{KCL}$ & & 7.7 & 7.7 & 7.7 & 7.6 & 7.8 & 7.8 & 7.7 \\
C-org & $\%$ & 0.5 & 0.4 & 0.4 & 0.5 & 0.4 & 0.4 & 0.4 \\
OS & $\%$ & 1.1 & 0.8 & 0.9 & 1 & 0.9 & 0.9 & 0.9 \\
C-tot & $\mathrm{g} \mathrm{C} / 100 \mathrm{~g}$ & 1.1 & 1 & 1 & 1.1 & 1 & 1.1 & 1.1 \\
N-tot & $\mathrm{mg} \mathrm{N} / \mathrm{kg}$ & 480 & 450 & 430 & 470 & 400 & 460 & 448 \\
C/N & & 22.9 & 22.2 & 23.3 & 23.4 & 25.0 & 23.9 & 23.5 \\
C-anorg & $\%$ & 0.55 & 0.51 & 0.54 & 0.53 & 0.58 & 0.55 & 0.54 \\
Koolzure kalk & $\%$ & 3.9 & 3.6 & 3.8 & 3.7 & 4.1 & 3.9 & 3.8 \\
\hline
\end{tabular}




\section{Bijlage 7 Saldoberekening walnoot}

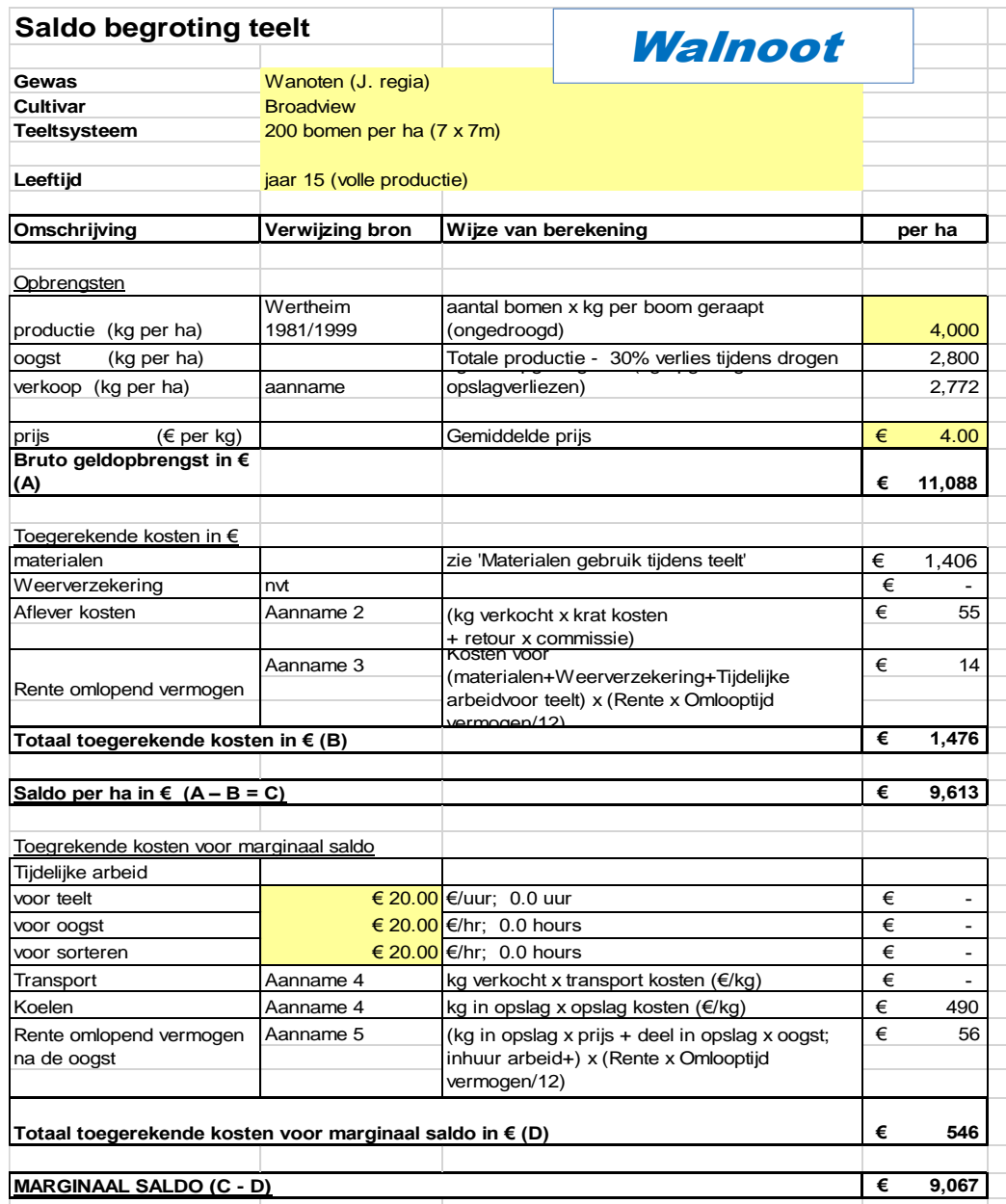

\begin{tabular}{|c|c|c|c|}
\hline \begin{tabular}{|l|} 
Aanname 1 \\
verliezen tijdens drogen \\
deel in opslag \\
verliezzen in opslag \\
\end{tabular} & $\begin{array}{r}\mathbf{k g ~ s o l d} \\
30 \% \\
50 \% \\
2 \% \\
\end{array}$ & & \\
\hline & & & \\
\hline Aanname 2 & & & \\
\hline $\begin{array}{l}\text { krat kosten } \\
\text { veiling kosten }\end{array}$ & $€ \quad 0.02$ & $/ \mathrm{kg}$ & \\
\hline velling kosten & $0.00 \%$ & & \\
\hline Aanname 3 & & & \\
\hline Rente & $2 \%$ & & \\
\hline Omlooptijd vermogen & & maanden & \\
\hline Aanname 4 & & & \\
\hline opslag kosten (€/kg) & $\begin{array}{ll}€ & 0.05 \\
€ & 0.10 \\
\end{array}$ & $\begin{array}{l}\text { tot en met december } \\
\text { maanden na december }\end{array}$ & \\
\hline transport kosten $(€ / \mathrm{kg})$ & $€$ & $/ \mathrm{kg}$ & \\
\hline Aanname 5 & & & \\
\hline opslag tijd & & maanden & \\
\hline Inzet arbeid oogst \& sortere & & & \\
\hline pluksnelheid & & $\mathrm{kg} / \mathrm{uur}$ & \\
\hline \% inzet arbeid voor oogst & $100 \%$ & & \\
\hline aanv arbeidsuraagfixed labour & & uur/ha & \\
\hline sorteer snelheid & & $\mathrm{kg} / \mathrm{uur}$ & \\
\hline$\%$ inzet vaste arbeid voor sort & $100 \%$ & & \\
\hline aanv. Inzet vaste krachten & & uur/ha & \\
\hline Arbeid inzet & Uitleg bere & kening & uren/ha \\
\hline \begin{tabular}{|l} 
teelt; inhuur arbeid \\
teelt; vaste medewe.
\end{tabular} & see 'Inzet al & arbeid voor teelt' & $\begin{array}{r}0.0 \\
112.0\end{array}$ \\
\hline oogst; inhuur arbeid & $=0.0 \times 400$ & $0 / 100$ uur & 0.0 \\
\hline oogst; vastemedewerkers & $=1.0 \times 400$ & $0 / 100+$ uur & 40.0 \\
\hline sorteren; inhuur arbeid & $=0.0 \times 400$ & 0 / 200 uur & 0.0 \\
\hline $\begin{array}{l}\text { sorteren; vaste } \\
\text { arbeidskrachten }\end{array}$ & $=1.0 \times 400$ & 0 / 200 uur & 20.0 \\
\hline
\end{tabular}

\begin{tabular}{|c|c|c|}
\hline Materialen gebruik tijdens teelt & per ha & \\
\hline Org. mest/ kunstmest & $€ \quad 100$ & \\
\hline Gewasbescherming & $€ \quad 100$ & \\
\hline overige materialen & $€ \quad 100$ & \\
\hline Onkruidbeheersing & & \\
\hline Diesel en benzine & & \\
\hline Energie (geen brandstof) & & \\
\hline Bijen & $€$ & \\
\hline Nachtvorstbestrijding & $€ \quad 400$ & \\
\hline Totale materiaal kosten & $\in \quad 1,406$ & \\
\hline Inzet arbeid voor teelt & vast & inhuur \\
\hline & uur/ha & $\underline{\text { uur/ha }}$ \\
\hline Org. Mest/ kunstmest & 8.0 & \\
\hline Onkruid bestrijding - mechanisch & 0.0 & \\
\hline Onkruid bestrijding chemisch & 16.0 & \\
\hline $\begin{array}{l}\text { Gewasbescherming } \\
\text { wild controle }\end{array}$ & 16.0 & \\
\hline wild controle & 8.0 & \\
\hline $\begin{array}{l}\text { wintersnoei } \\
\text { zomersnoei }\end{array}$ & $\begin{array}{l}24.0 \\
24.0\end{array}$ & \\
\hline $\begin{array}{l}\text { Zomersnoei } \\
\text { Nachtvorstbestrijding }\end{array}$ & $\begin{array}{l}24.0 \\
16.0\end{array}$ & \\
\hline Totaal & 112.0 & \\
\hline Totale a & & \\
\hline
\end{tabular}

Totale arbeidsinzet teelt 


\section{Bijlage 8 Saldoberekening hazelnoot}

\begin{tabular}{|c|c|c|c|c|}
\hline \multicolumn{2}{|c|}{ Saldo begroting gewas } & \multirow{2}{*}{\multicolumn{2}{|c|}{ Hazelnoten }} & \\
\hline Gewas & \multirow{4}{*}{\multicolumn{2}{|c|}{$\begin{array}{l}\text { Hazelnoten } \\
\text { divers } \\
\text { enkelrij, } 4,5 \text { bij } 2,5 \text { meter, } 888 \text { bomen/ha } \\
\text { een jarig plantmateriaal } \\
\text { jaar } 8 \text { (vol productie) }\end{array}$}} & \\
\hline Cultivar & & & & \\
\hline Teeltsysteem & & & \\
\hline Leeftijd & & & & \\
\hline Omschrijving & Verwijzing bron & Wijze van berekening & \multicolumn{2}{|c|}{ per ha } \\
\hline \multicolumn{5}{|l|}{ Opbrengsten } \\
\hline productie (kg per ha) & Wertheim 1999 & hoeveelstruiken x kg per struik (ongepeld) & & 2,778 \\
\hline $\begin{array}{ll}\text { Geoogst } & \text { (kg per ha) } \\
\end{array}$ & Wertheim 1999 & Totale opbrengst - verliezen tijdens de oogst & & 2,500 \\
\hline Verkocht (kg per ha) & aanname & opslagverliezen) & & 2,500 \\
\hline$(€$ per kg) & & Gemiddelde prijs & $\epsilon$ & 4.00 \\
\hline $\begin{array}{l}\text { Bruto geldopbrengst in } € \\
\text { (A) }\end{array}$ & & & $\epsilon$ & 10,001 \\
\hline \multicolumn{5}{|l|}{ Toegerekende kosten in $€$} \\
\hline \begin{tabular}{|l|l} 
Materialen \\
\end{tabular} & KWIN 2009/2010 & Zie 'Materialen gebruik tijdens teelt' & $€$ & 1,000 \\
\hline Hagelverzekering & & & $€$ & \\
\hline Aflever kosten & Aanname 2 & \begin{tabular}{|l|} 
\\
(kg verkocht $x$ krat kosten \\
+ retour $x$ commissie)
\end{tabular} & $€$ & 75 \\
\hline Rente omlopend vermogen & Aanname 3 & $\begin{array}{l}\text { Kosten voor } \\
\text { (Materialen+Hagelverzekering+Tijdelijke } \\
\text { arbeidvoor teelt) } \text { ( (Rente x Omlooptijd }\end{array}$ & $€$ & 10 \\
\hline \multicolumn{2}{|c|}{ Totaal toegerekende kosten in $€$ (B) } & & 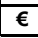 & 1,085 \\
\hline \multicolumn{2}{|c|}{ Saldo per ha in $€(A-B=C)$} & & $\epsilon$ & 8,916 \\
\hline \multicolumn{5}{|c|}{ Toegrekende kosten voor marginaal saldo } \\
\hline \multicolumn{5}{|c|}{\begin{tabular}{|l|l|} 
Tijdelijke arbeid \\
\end{tabular}} \\
\hline voor teelt & \multirow{3}{*}{$\begin{array}{l}€ 20.00 \\
\in 20.00 \\
€ 20.00\end{array}$} & $€ /$ uur; 0.0 uur & \multicolumn{2}{|c|}{$\epsilon$} \\
\hline voor oogst & & $€ / \mathrm{hr} ; 0.0$ uur & $€$ & $-{ }^{-}$ \\
\hline voor sorteren & & $\epsilon / \mathrm{hr} ; 0.0$ uur & $€$ & - \\
\hline Transport & Aanname 4 & $\mathrm{~kg}$ verkocht $\mathrm{x}$ transport kosten $(€ / \mathrm{kg})$ & $\epsilon$ & \\
\hline Koelen & \begin{tabular}{|l|} 
Aanname 4 \\
Aanname 5
\end{tabular} & kg in opslag $\times$ opslag kosten $(€ / \mathrm{kg})$ & $\epsilon$ & 500 \\
\hline $\begin{array}{l}\text { Rente omlopend vermogen } \\
\text { na de oogst }\end{array}$ & Aanname 5 & $\begin{array}{l}\text { (kg in opslag } \times \text { prijs }+ \text { Part in storage } \times \text { oogst; } \\
\text { inhuur arbeid+) } \times(\text { Rente } \times \text { Omlooptijd } \\
\text { vermogen/12) }\end{array}$ & & 50 \\
\hline \multicolumn{3}{|c|}{ Totaal toegerekende kosten voor marginaal saldo in $€$ (D) } & $€$ & 550 \\
\hline
\end{tabular}

\begin{tabular}{|c|c|c|c|}
\hline Aanname 1 & kg sold & & \\
\hline verliezen tijdens oogst & $10 \%$ & & \\
\hline Part in storage & $50 \%$ & & \\
\hline Verliezen in opslag & $0 \%$ & & \\
\hline \multicolumn{4}{|l|}{ Aanname 2 } \\
\hline krat kosten & $€ \quad 0.03$ & $/ \mathrm{kg}$ & \\
\hline veiling kosten & $0.00 \%$ & & \\
\hline \multicolumn{4}{|l|}{ Aanname 3} \\
\hline \multicolumn{4}{|l|}{ Rente } \\
\hline Omlooptijd vermogen & \multicolumn{2}{|c|}{6 maanden } & \\
\hline \multicolumn{4}{|l|}{ Aanname 4} \\
\hline \multirow[t]{2}{*}{ 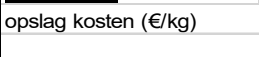 } & $€ \quad 0.10$ & tot en met december & \\
\hline & 0.10 & maanden na december & \\
\hline transport kosten $(€ / \mathrm{kg})$ & $\begin{array}{llllllllll} & \\
\end{array}$ & $1 \mathrm{~kg}$ & \\
\hline \multicolumn{4}{|l|}{ Aanname 5 } \\
\hline opslag tijd & \multicolumn{2}{|c|}{6 maanden } & \\
\hline \multicolumn{4}{|c|}{ Inzet arbeid oogst \& sorteren } \\
\hline \multicolumn{2}{|c|}{ oogstsnelheid } & $\mathrm{kg} / \mathrm{uur}$ & \\
\hline$\%$ inzet arbeid voor oogst & $100 \%$ & & \\
\hline aanv arbeidsvraagfixed lab & \multicolumn{2}{|c|}{$\begin{array}{r}100 \% \\
7.5 \text { uur/ha }\end{array}$} & \\
\hline sorteer snelheid & \multicolumn{2}{|c|}{$200 \mathrm{~kg} / \mathrm{uur}$} & \\
\hline$\%$ inzet vaste arbeid voor : & \multicolumn{2}{|l|}{$100 \%$} & \\
\hline aanv. Inzet vaste krachten & \multicolumn{2}{|c|}{0.0 uur/ha } & \\
\hline \begin{tabular}{|l|} 
Arbeid inzet \\
\end{tabular} & \multicolumn{2}{|c|}{ Uitleg berekening } & uren/ha \\
\hline teelt; inhuur arbeid & & 0.0 \\
\hline see 'Inzet arbeid voor teelt' & & & 59.0 \\
\hline oogst; inhuur arbeid & \multicolumn{2}{|c|}{$=0.0 \times 2500 / 200$ uur } & 0.0 \\
\hline oogst; vastemedewerkers & \multicolumn{2}{|c|}{$=1.0 \times 2500 / 200+8$ uur } & 20.0 \\
\hline sorteren; inhuur arbeid & \multicolumn{2}{|c|}{$=0.0 \times 2500 / 200$ uur } & 0.0 \\
\hline $\begin{array}{l}\text { sorteren; vaste } \\
\text { arbeidskrachten }\end{array}$ & \multicolumn{2}{|c|}{$=1.0 \times 2500 / 200$ uur } & 12.5 \\
\hline
\end{tabular}

\begin{tabular}{|c|c|c|}
\hline Materialen gebruik tijdens teelt & per ha & \\
\hline org. Mest/ kunstmest & $€ \quad-$ & \\
\hline Gewasbescherming 1e jaar & $€$ & \\
\hline Gewasbescherming overige jaren & $€$ & \\
\hline Onkruidbeheersing & $€$ & \\
\hline Diesel en benzine & $€$ & \\
\hline Energie (geen brandstof) & $€$ & \\
\hline Palen & $€$ & \\
\hline Plantmateriaal & $€$ & \\
\hline Overig & $€ 1,000$ & totaal vig B \\
\hline Totale materiaal kosten & $€ 1,000$ & \\
\hline Inzet arbeid voor teelt & vast & inhuur \\
\hline & uur/ha & $\underline{\text { uur/ha }}$ \\
\hline Org. Mest/ kunstmest & 3.0 & \\
\hline Onkruid bestrijding - mechanisch & 20.0 & \\
\hline Onkruid bestrijding chemisch & 0.0 & \\
\hline Gewasbescherming & 0.0 & \\
\hline wild beheer & 4.0 & \\
\hline wintersnoei & 12.0 & \\
\hline zomersnoei & 5.0 & \\
\hline oogst & 0.0 & \\
\hline maaien & 15.0 & \\
\hline Totaal & 59.0 & \\
\hline Totale arbeidsinzet teelt & & \\
\hline Aanname 6: & & \\
\hline Verzekering extreem weer & & \\
\hline Adviced sum to be insured: & & \\
\hline returns: & & $€$ \\
\hline plantings: & & $€$ \\
\hline premium extreme rain / drought * & $0.70 \%$ & $€$ \\
\hline premium frostglaze/snow/lightning ** & $0.65 \%$ & $€$ \\
\hline premium hail ${ }^{\star \star \star}$ & $5.52 \%$ & $€$ \\
\hline * insurance concerns returns & & \\
\hline ** insurance concerns ret. \& plant. & & \\
\hline *** premium first year (no bonus/malu & & \\
\hline total premium & & $€$ \\
\hline state subsidy (maximum) & $60.60 \%$ & \\
\hline Premie na subsidie & & $\epsilon$ \\
\hline
\end{tabular}




\section{Bijlage 9 Programma Nederlandse Noten- dag (Zoelen, 10 november, 2018)}

\section{EDERLANDSE OTENVERENIGING}

\section{Programma NEDERLANDSE NOTENDAG}

Datum: 10 november 2018 Locatie: Mobipers, Retsezijstratt 6, 4011 JP Zoelen

\subsection{0 u Opening}

13.30 u Workshop "Walnoot beoordelen" (Vincent Turkelboom)

Rondleiding Mobipers (denk aan laarzen!)

14.00 u Presentatie Biobased kansen notenteelt (Noēll van Dooren, Van Hall Larenstein)

14.30 u Workshop "Walnoot beoordelen" (Vincent Turkelboom)

Rondleiding Mobipers (denk aan laarzen!)

15.00 u Presentatie Notenprojecten (Ton Baltissen, Cropeye)

15.30 u Presentatie Nieuwe ontwikkelingen in de notenteelt (Henk van Reuler, WUR)

16.00 Afsluiting

De gehele middag aijn staat er een keur van producten (plantmateriaal, noten, pasta, likeur enz.) van verschillende bedrijven uitgestald. Tenslotte staan er noten van verschillende rassen, die kunnen worden geproefd en beoordeeld.

We wensen u een vruchtbare notendag! 


\section{Bijlage 10 Presentatie op de Eerste Nederlandse Notendag(Zoelen, 10 november, 2018)}

Nieuwe ontwikkelingen in het onderzoek

10 november, 2018 Eerste Nederlandse Notendag, Zoelen Henk van Reuler, Fogelina Cuperus, Maureen Schoutsen en Andrew Dawson

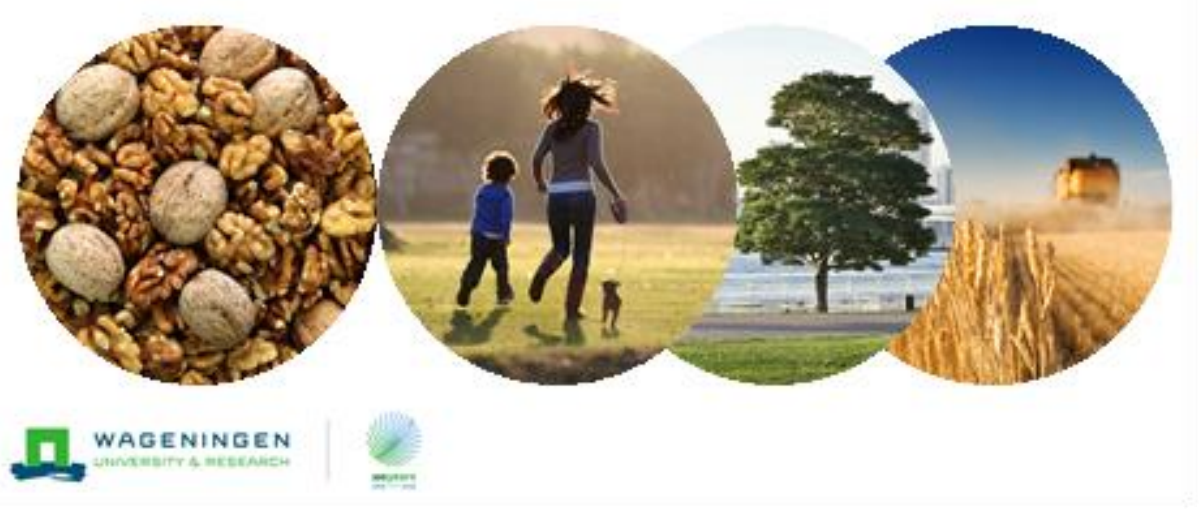

\section{Inhoud}

- Aanleiding

- Activiteiten

- Vervolg 


\section{Aanleiding}

\section{Klimaatakkoord}

\section{Doel}

- Verlagen van de nationale broeikasgasuitstoot in 2030 met $49 \%$ terug te dringen ten opzichte van 1990

Sectortafel Landbouw en Landgebruik

\section{Agenda}

o.a. Notenteelt - vastlegging van $\mathrm{CO}_{2}$ in bodem en gewas

\section{Aanleiding}

- Op dit moment areaal walnoten + hazelnoten $\approx 100$ ha

- '80 Wertheim en Goedegebure - De teelt van hazelnoten

Wertheim - De teelt van walnoten

- Daarna weinig onderzoek meer 


\section{Activiteiten}

- Literatuurstudie - relevante ontwikkelingen elders

- Opzetten van een gebruikswaarde onderzoek - EUFRIN

- $\mathrm{CO}_{2}$ vastlegging in gewas en bodem - monitoren, modellen

- Economische scenario studies

- Communicatie

DAGENINGEN

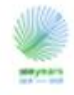

\section{Activiteiten}

Gemiddelde hazelnootopbrengst (3-12 jaar) in Gironde (F) Effect van CV en plantdichtheid

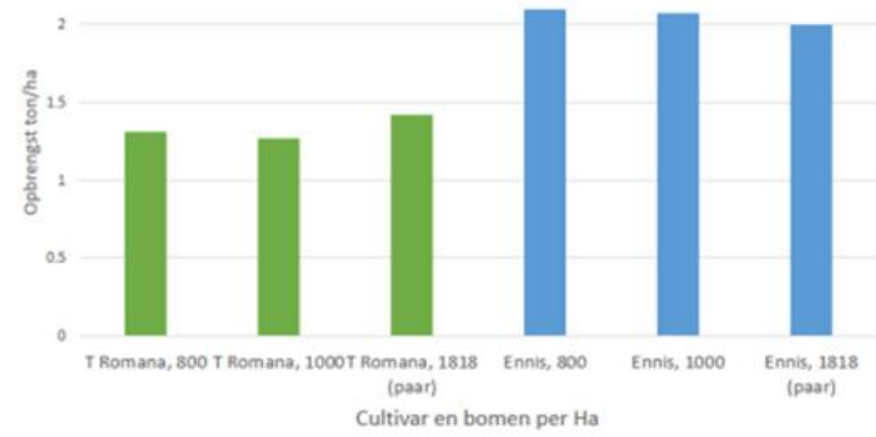

DAGENINGEN

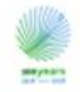

(Germaine and Sarraquigne, 1996) 


\section{Activiteiten}

Gemiddelde hazelnootopbrengst (7-11 jaar) in Cuneo (I)

Effect van CV en plantdichtheid

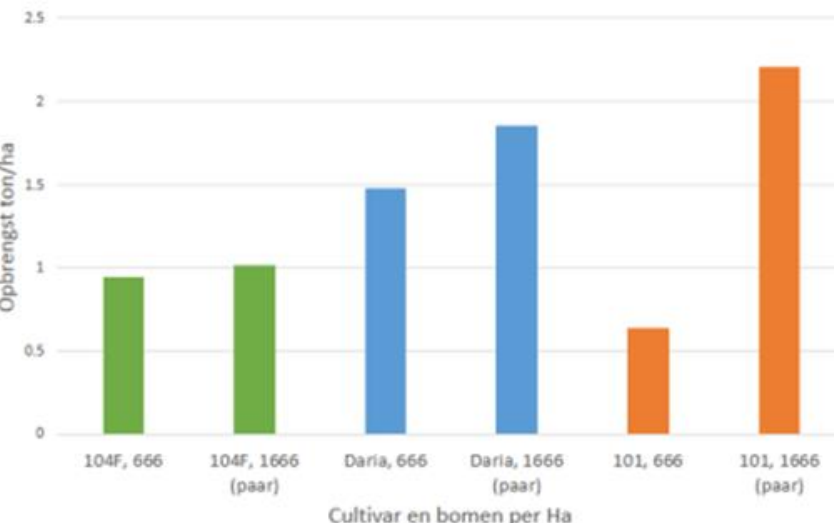

\section{Activiteiten}

Gemiddelde walnootopbrengst (5-9 jaar) in California.

Effect van CV, plantdichtheid en onderstam

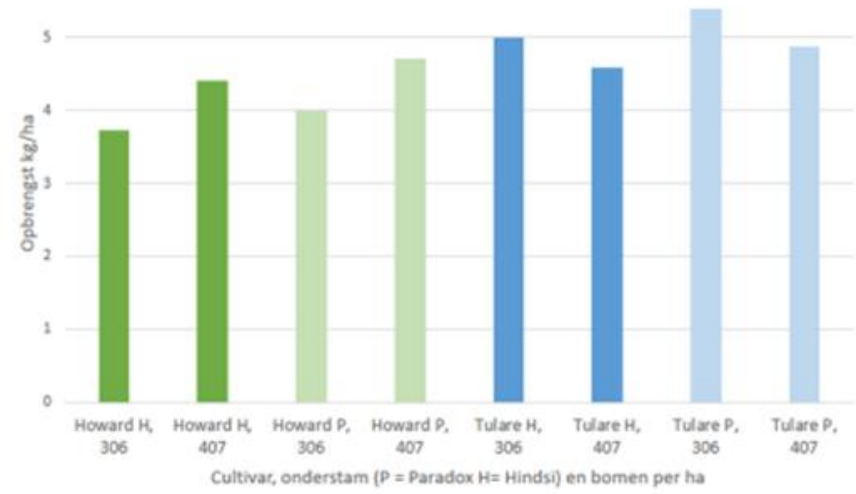




\section{Activiteiten}

- $\mathrm{Nu} \approx 100$ ha noten

- Lastig om een inkomen mee te verdienen

- Nieuwe verdienmodellen

- Beloning agro-ecosysteemdiensten

- Bufferzone rond natuurgebieden

- Voedselbossen

- ....

WAGENINGEN

\section{Agroforestry}

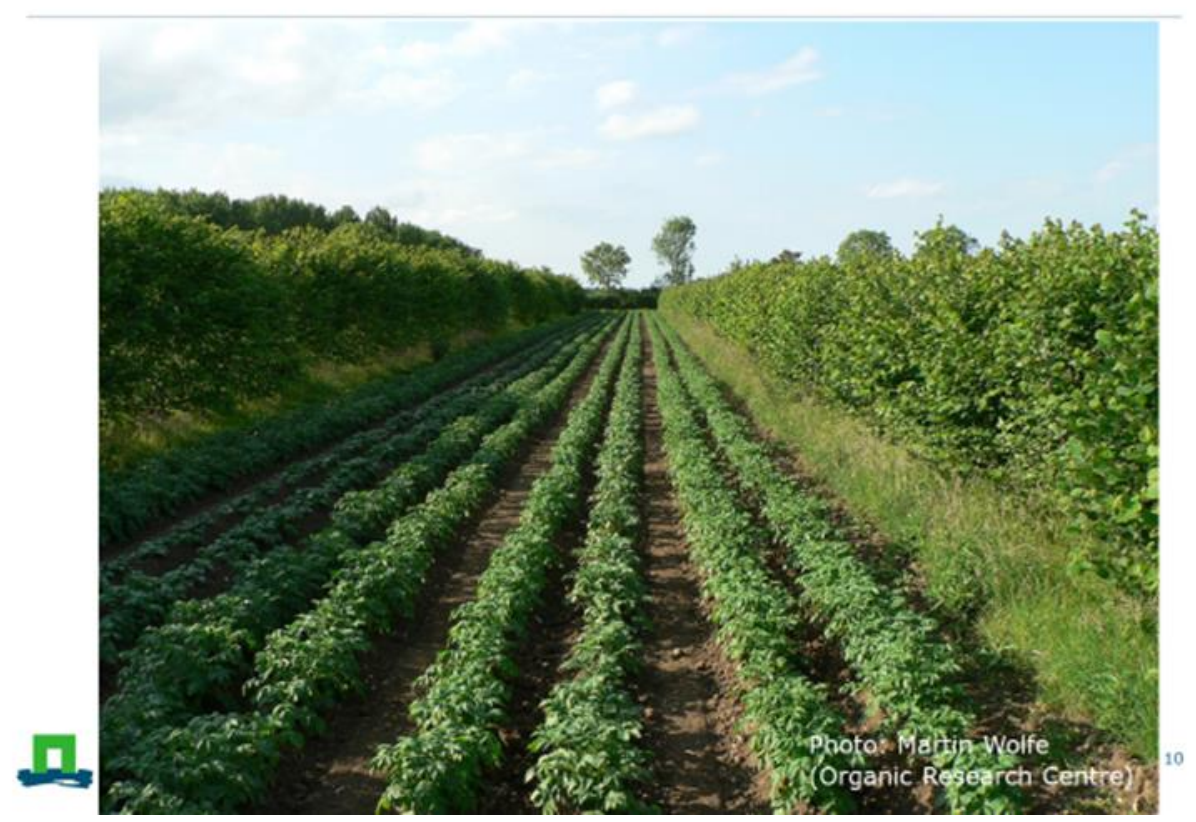




\section{Vervolg}

- Bijdrage aan Klimaatopdracht

- 2019 en verder?

- Meerjarige gewassen vragen om een meerjarige aanpak

- De Notenvereniging speelt hierbij een belangrijke rol

WAGENINGEN

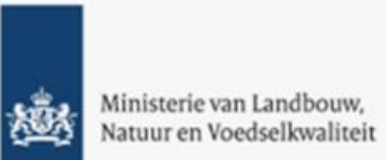

\section{Dank voor uw} aandacht

Vragen?

henk.vanreuler@wur.nl

fogelina.cuperus@wur.nl

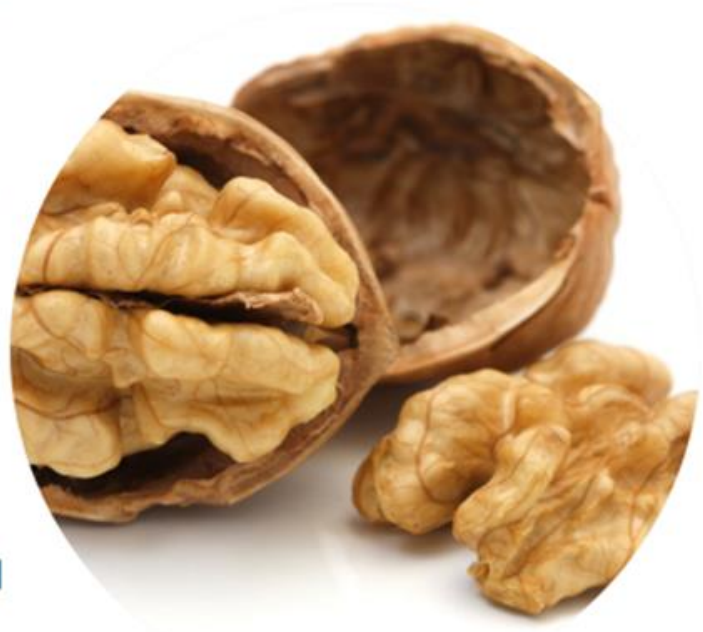

1. WAGENINGEN 


\section{Bijlage 11 Infosheet project Nederlandse Notenteelt (december, 2018)}

\section{Project 'Nederlandse Notenteelt'}
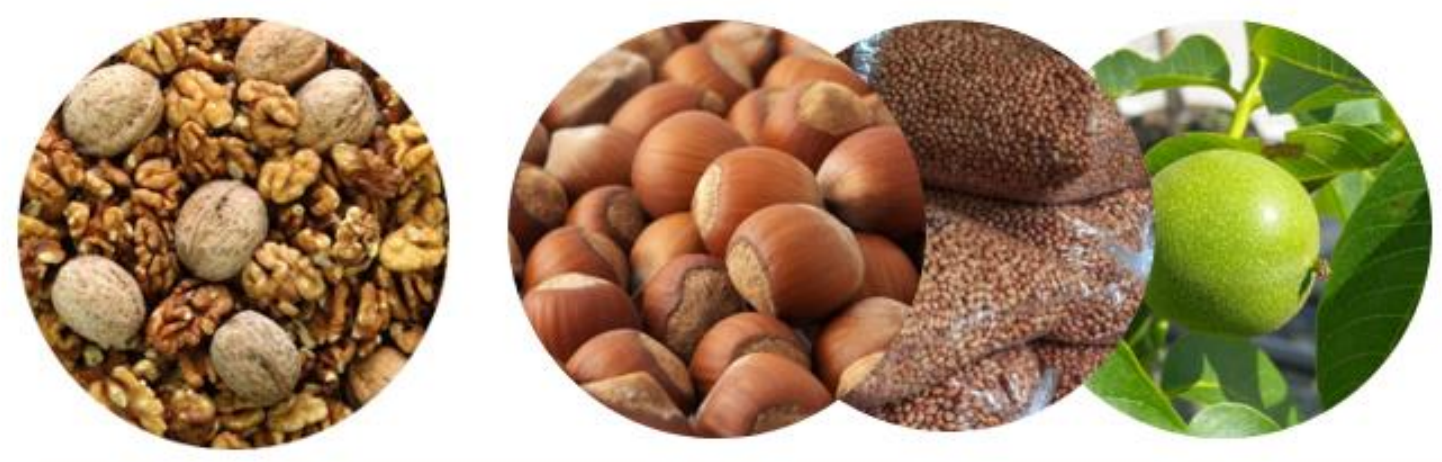

Notenteelt en klimaat

Binnen het Klimaatakkoord heeft de Klimaattafel Land en Landgebruik de opdracht gekregen de uitstoot van broeikasgassen in 2030 met $49 \%$ te verminderen. De vastlegging van $\mathrm{CO}_{2}$ in bodems en houtige gewassen speelt een belangrijke rol om deze doelstelling te realiseren. Daarnaast leveren deze gewassen een bijdrage aan de biodiversiteit en kwaliteit van het landschap. De notenteelt levert bovendien een alternatieve bron voor eiwit en gezonde vetten.

Het Ministerie van Landbouw, Natuur en Voedselkwaliteit heeft aan Wageningen Universiteit \& Research geld ter beschikking gesteld voor het ontsluiten en ontwikkelen van solide kennis op het gebied van notenteelt in Nederland, evenals voor het verkrijgen van inzicht in de effecten ervan op agroecosysteemdiensten (m.n. koolstofvastlegging).
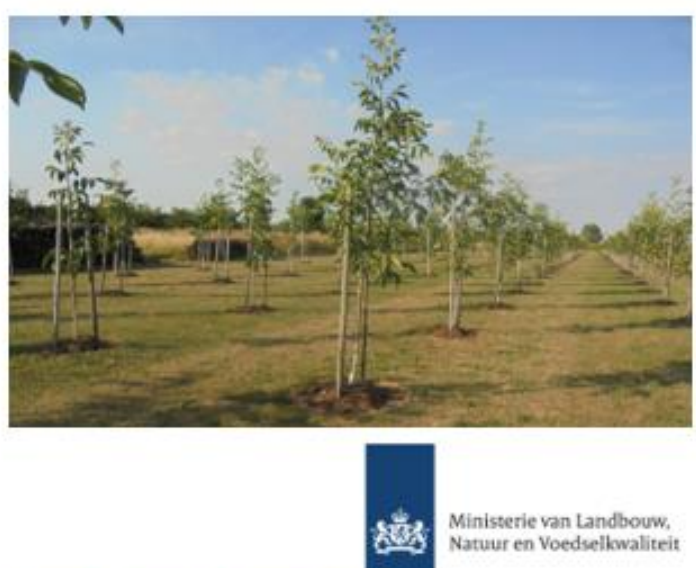

Achtergrond en projectonderdelen

Op dit moment bedraagt het areaal noten (wal-en hazelnoten) in Nederland ongeveer 100 hectare. Recent is echter de interesse in notenteelt toegenomen. Dit heeft te maken met de toenemende vraag naar (lokaal en duurzaam geproduceerde) noten én met de zoektocht binnen de agrarische sector naar meer duurzame plantaardige productiesystemen (natuurinclusief en klimaatbestendig) en de bredere maatschappelijke interesse in systemen als agroforestry en voedselbossen.

De toegenomen belangstelling voor de notenteelt bij ondernemers heeft er toe geleid dat in juli 2017 de Nederlandse Notenvereniging is opgericht. De Notenvereniging heeft een belangrijke rol gespeeld om notenteelt op de agenda te zetten van de Klimaattafel Landbouw en Landgebruik. Onderhavig project wordt in samenwerking met de vereniging uitgevoerd.

\section{We onderzoeken:}

De aanwezige kennis en praktijkervaring met notenteelt;

de potentiele rol van notenteelt in de klimaatmitigatie in Nederland;

veelbelovende wal- en hazelnotensoorten en cultivars i.c.m. onderstammen;

geschikte bestaande notenboomgaarden en referentie percelen voor de uitvoering van nulmetingen op gebied van koolstofopslag; scenario's, zowel op economisch vlak als van koolstofopslag in boom en bodem. 


\section{Deskstudie kennis notenteelt}

In de jaren ' 80 zijn er enkele belangrijke studies over de notenteelt verschenen, maar daarna heeft het onderzoek in Nederland min of meer stil gelegen. De ontwikkelingen van na 1980 in belangrijke productiegebieden met vergelijkbare omstandigheden als in Nederland worden nu in kaart gebracht. Hierbij gaat het met name om de agronomische aspecten zoals plantdichtheden en opbrengst. Hieronder een voorbeeld:

Opbrengst in $\mathrm{kg} / \mathrm{boom}$

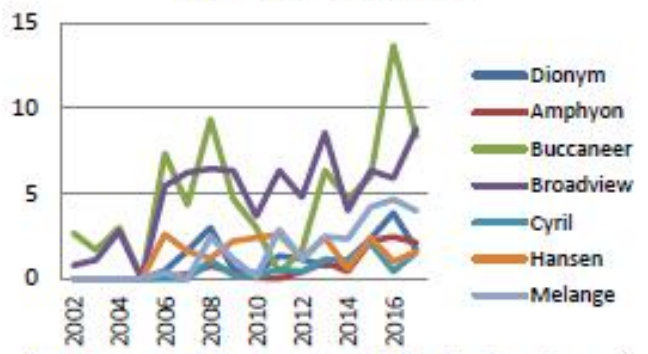

De opbrengst per boom van verschillende walnootrassen in de periode 2002-2017 in de N.O. polder.

\section{Veelbelovende rassen}

In het buitenland zijn veel nieuwe rassen beschikbaar. We onderzoeken welke van deze nieuwe rassen interessant zijn om onder Nederlandse omstandigheden getest te worden. Voor de teelt in Nederland zijn voor bijvoorbeeld walnoten naast de opbrengst en kwaliteit van de noten ook eigenschappen zoals late bloei, lateraal dragend en ziektegevoeligheid belangrijk.

\section{Koolstofopslag metingen}

Onderzoek naar de bijdrage van boomgewassen aan de vastlegging van $\mathrm{CO}_{2}$ (in biomassa en organisch stof) is lange termijnonderzoek.

Daarvoor is het nodig om nu de uitgangssituatie van een aantal percelen vast te leggen en deze percelen over een langere periode te volgen. We kijken naar koolstofopslag in boven- en ondergrondse biomassa, de bodem, de graslaag en doen metingen in een viertal notengaarden en referentiepercelen.

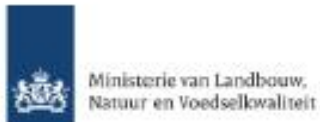

WAGENINGEN

UNIVERSITY \& RESEARCH

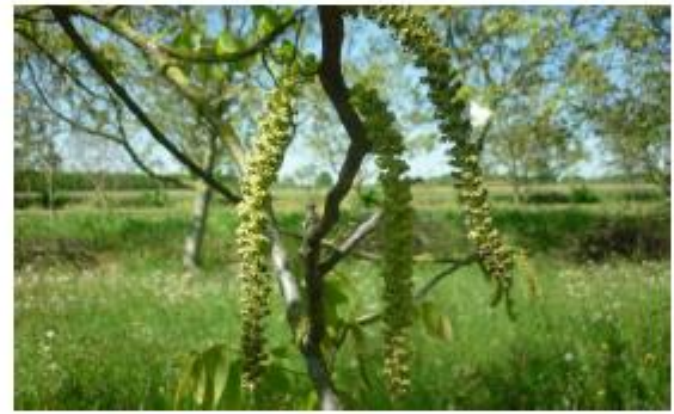

Economische scenario's

Er kunnen op dit moment maar weinig notentelers een volwaardig inkomen met hun teelt verdienen. Het is belangrijk om op een eenduidige manier het saldo van de teelt te berekenen. Dit maakt een goede vergelijking met alternatieve teelten mogelijk, evenals een vergelijking tussen verschillende teeltsystemen (zodat bijvoorbeeld het effect van een hogere plantdichtheid berekend kan worden). We werken momenteel aan een simpel rekenmodel hiervoor.

\section{Rapport begin 2019}

Een rapportage van de bevindingen van het project 'Nederlandse Notenteelt' (1 1 ste fase) wordt begin 2019 verwacht. Vervolgfinanciering is noodzakelijk om het onderzoek verder voort te zetten. Meerjarige gewassen vragen immers om een meerjarige aanpak!

Onderzoeksvragen?

Mocht u specifieke onderzoeksvragen hebben over notenteelt, laat het ons weten! We zullen samen met de Notenvereniging proberen uw onderzoeksvragen mee te nemen in

meejarige projecten.

Meer informatie ?

Henk van Reuler I

henk.vanreuler@wur.n!

Maureen Schoutsen |

maureen.schoutsen@wur.nl

U kunt zich ook aanmelden voor onze

agroforestry nieuwsbrief via:

https://www.wur.nl/nl/project/5-vragen-over-

Agroforestry-bomen-en-landbouw-op-eenperceel.htm (blauwe knop halverwege de pagina). 


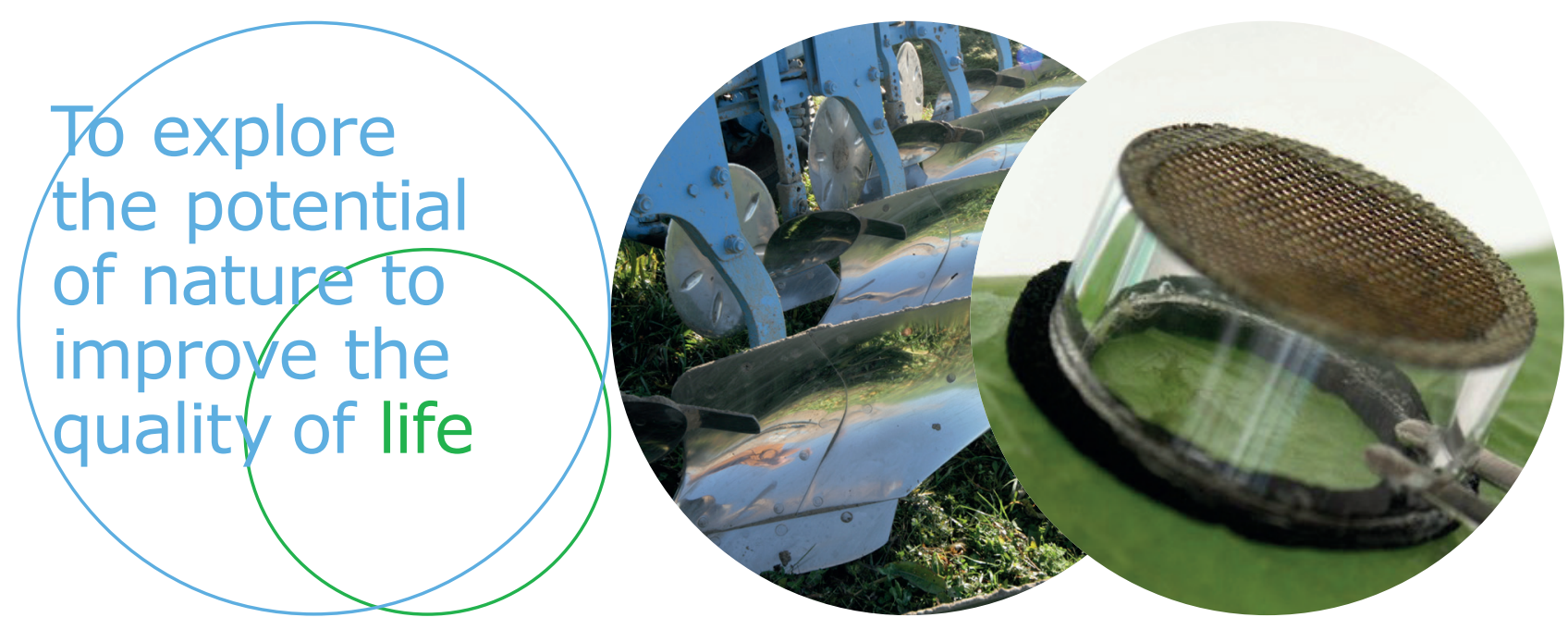

Wageningen University \& Research

\section{Open Teelten}

Edelhertweg 1

Postbus 430

8200 AK Lelystad

T (+31)3202911 11

\section{www.wur.nl/openteelten}

Rapport WPR-843
De missie van Wageningen University \& Research is 'To explore the potential of nature to improve the quality of life'. Binnen Wageningen University \& Research bundelen 9 gespecialiseerde onderzoeksinstituten van stichting DLO en Wageningen University hun krachten om bij te dragen aan de oplossing van belangrijke vragen in het domein van gezonde voeding en leefomgeving. Met ongeveer 30 vestigingen, 6.000 medewerkers en 9.000 studenten behoort Wageningen University \& Research wereldwijd tot de aansprekende kennisinstellingen binnen haar domein.

De integrale benadering van de vraagstukken en de samenwerking tussen verschillende disciplines vormen het hart van de unieke Wageningen aanpak. 